This document was prepared in conjunction with work accomplished under Contract No. DE-AC09-96SR18500 with the U. S. Department of Energy.

\title{
DISCLAIMER
}

This report was prepared as an account of work sponsored by an agency of the United States Government. Neither the United States Government nor any agency thereof, nor any of their employees, nor any of their contractors, subcontractors or their employees, makes any warranty, express or implied, or assumes any legal liability or responsibility for the accuracy, completeness, or any third party's use or the results of such use of any information, apparatus, product, or process disclosed, or represents that its use would not infringe privately owned rights. Reference herein to any specific commercial product, process, or service by trade name, trademark, manufacturer, or otherwise, does not necessarily constitute or imply its endorsement, recommendation, or favoring by the United States Government or any agency thereof or its contractors or subcontractors. The views and opinions of authors expressed herein do not necessarily state or reflect those of the United States Government or any agency thereof. 


\section{DWPF RECYCLE EVAPORATOR SHIELDED CELLS TESTING}

T. L. Fellinger

D. T. Herman

M. E. Stone

July 2005

Immobilization Technology Section

Savannah River National Laboratory

Aiken, SC 29808

Prepared for the U.S. Department of Energy Under Contract Number DEAC09-96SR18500

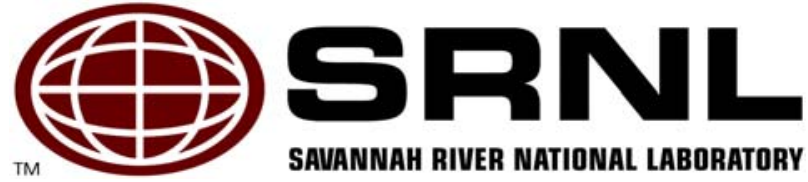




\title{
DISCLAIMER
}

This report was prepared by Westinghouse Savannah River Company (WSRC) for the United States Department of Energy under Contract No. DE-AC09-96SR18500 and is an account of work performed under that contract. Neither the United States Department of Energy, nor WSRC, nor any of their employees makes any warranty, expressed or implied, or assumes any legal liability or responsibility for the accuracy, completeness, or usefulness, of any information, apparatus, or product or process disclosed herein or represents that its use will not infringe privately owned rights. Reference herein to any specific commercial product, process, or service by trademark, name, manufacturer or otherwise does not necessarily constitute or imply endorsement, recommendation, or favoring of same by WSRC or by the United States Government or any agency thereof. The views and opinions of the authors expressed herein do not necessarily state or reflect those of the United States Government or any agency thereof.

\author{
Printed in the United States of America \\ Prepared For \\ U.S. Department of Energy
}


WSRC-TR-2005-00309

Revision 0

Key Words: $D W P F$, Recycle,

Evaporation, Antifoam

Retention: Permanent

\section{DWPF RECYCLE EVAPORATOR SHIELDED CELLS TESTING}

T. L. Fellinger

D. T. Herman

M. E. Stone

July 2005

Immobilization Technology Section Savannah River National Laboratory Aiken, SC 29808

Prepared for the U.S. Department of Energy Under Contract Number DEAC09-96SR18500

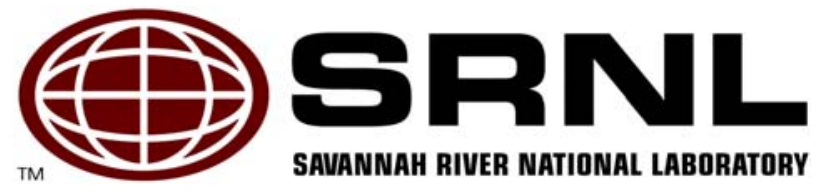




\section{REVIEWS AND APPROVALS}

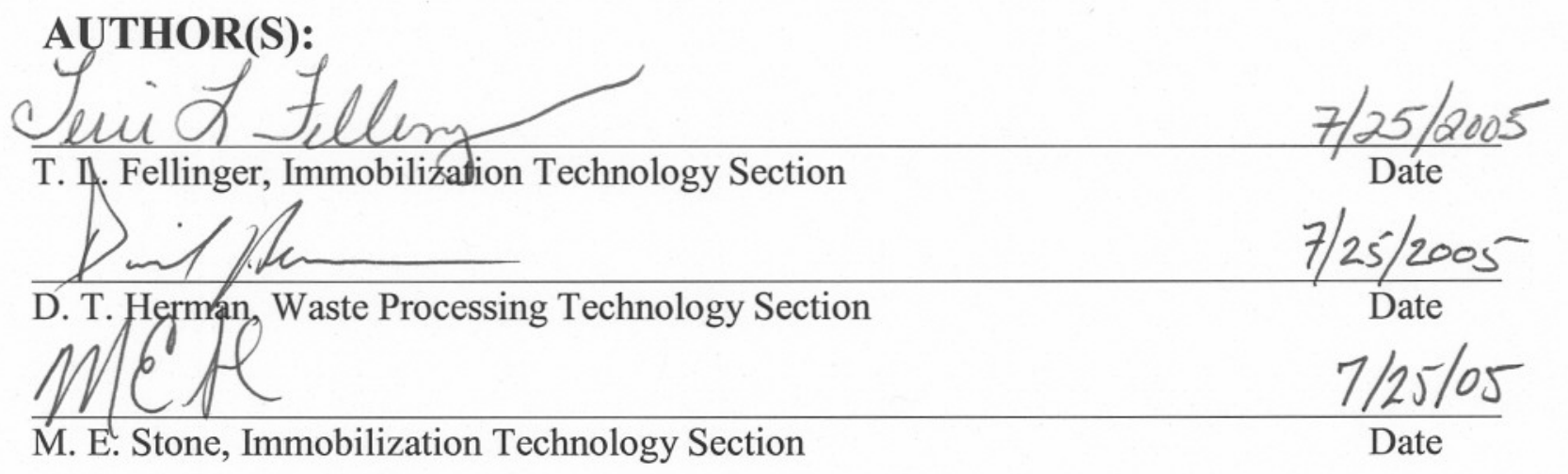

\section{TECHNICAL REVIEWERS:}

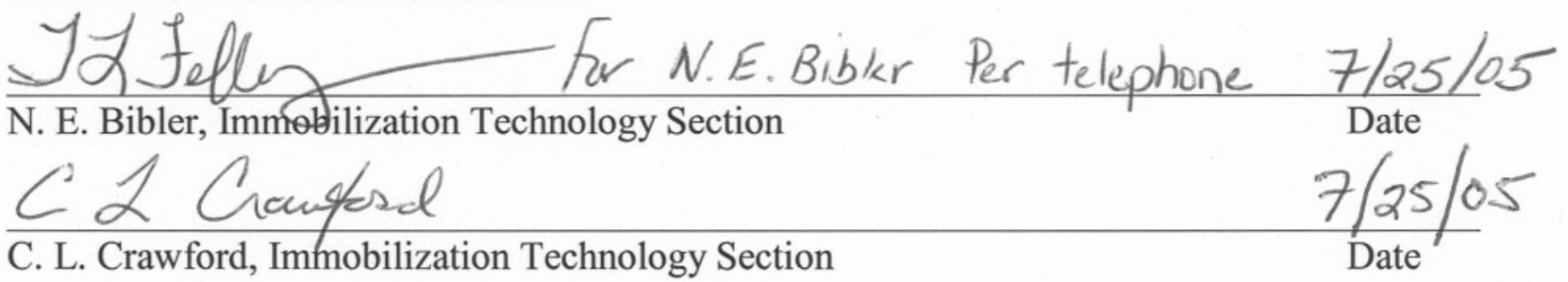

\section{APPROVERS}

\section{El Hetrahule}

E. W. Holtzscheifer, Manager, Immobilization Technology Section 


\section{EXECUTIVE SUMMARY}

Testing was performed to determine the feasibility and processing characteristics of evaporation of actual Defense Waste Processing Facility (DWPF) recycle material. Samples of the Off Gas Condensate Tank (OGCT) and Slurry Mix Evaporator Condensate Tank (SMECT) were transferred from DWPF to the Savannah River National Lab (SRNL) Shielded Cells and blended with De-Ionized (DI) water and a small amount of Slurry Mix Evaporator (SME) product. A total of $3000 \mathrm{~mL}$ of this feed was concentrated to approximately $90 \mathrm{~mL}$ during a semi-batch evaporation test of approximately 17 hours. One interruption occurred during the run when the feed tube developed a split and was replaced. Samples of the resulting condensate and concentrate were collected and analyzed. The resulting analysis of the condensate was compared to the Waste Acceptance Criteria (WAC) limits for the F/H Effluent Treatment Plant (ETP). Results from the test were compared to previous testing using simulants and OLI modeling.

Conclusions from this work included the following.

- The evaporation of DWPF recycle to achieve a $30 \mathrm{X}$ concentration factor was successfully demonstrated. The feed blend of OGCT and SMECT material was concentrated from $3000 \mathrm{~mL}$ to approximately $90 \mathrm{~mL}$ during testing, a concentration of approximately 33X.

- Foaming was observed during the run. Dow Corning 2210 antifoam was added seven times throughout the run at 100 parts per million (ppm) per addition. The addition of this antifoam was very effective in reducing the foam level, but the impact diminished over time and additional antifoam was required every 2 to 3 hours during the run.

- No scale or solids formed on the evaporator vessel, but splatter was observed in the headspace of the evaporator vessel. No scaling formed on the stainless steel thermocouple.

- The majority of the analytes met the F/H ETP WAC. However, the detection limits for selected species (Sr-90, Pu-238, Pu-240, Am-243, and Cm-244) exceeded the ETP WAC limits.

- I-129 was calculated to have exceeded the ETP WAC limits based on an assumed Decontamination Factor (DF) of 1 during evaporation.

- The DF for most species was limited by the detection limits of the sample analysis. Based on iron, manganese, total alpha, total beta, and other species, very low entrainment was noted and evaporator DF was $>10,000$ for non-volatile species.

- Very low DF's were obtained for selected species, especially mercury and formate. These species are present as volatile compounds and will exceed ETP WAC limits if sufficient concentrations are in the evaporator feed.

- The evaporator DF's for the radioactive test were in good agreement with simulant test results. Differences noted in the DF of selected species, such as Hg, were more likely attributed to analytical issues than differences in the performance of the two evaporators.

- The simulant appeared to be conservative in terms of foaming and scaling characteristics of the evaporator. The initial spike in foaming that occurred during all simulant runs did not occur during the Shielded Cells run and overall foaminess after 
the start of the test was controlled by antifoam additions. The splatter that was deposited during the radioactive test was less than the simulant runs and was more easily removed.

- The OLI model results were overly conservative due to the manner that entrainment of solids was incorporated into the model.

Recommendations from this work are:

- A camera and/or foam detection instrument should be included in the evaporator design to allow monitoring of the foaming behavior during operation.

- The potential for foam formation and high solids content should be considered during the design of the evaporator vessel.

- Continued evaluation of Dow Corning 2210 antifoam with simulants is warranted. The antifoam has been tested with simulated and actual recycle blends that represent normal operation. Additional tests that evaluate the performance of the antifoam with different recycle blends should be conducted.

- The OLI model results should be updated to reflect more representative values for entrainment of solids.

- Determination of the iodine DF for the recycle evaporator could be conducted with simulants, but the DF is expected to be very low. The DF required to meet the $\mathrm{F} / \mathrm{H}$ ETP WAC limit is 7.35 for the feed tested during the Shielded Cells test and a margin above that is needed to account for variability in the feed concentration. It is unlikely that the experimentally determined DF would allow I-129 to meet the WAC limits. 


\section{TABLE OF CONTENTS}

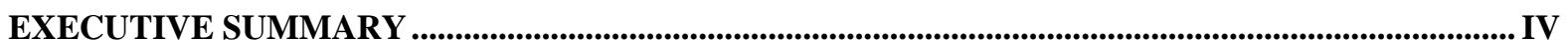

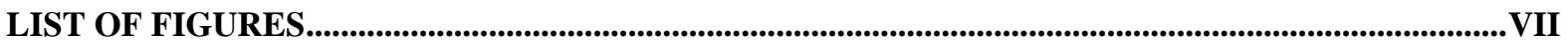

LIST OF TABLES................................................................................................................................................VII

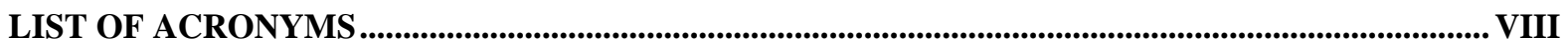

1.0 INTRODUCTION AND BACKGROUND ...............................................................................................

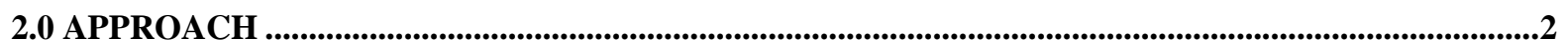

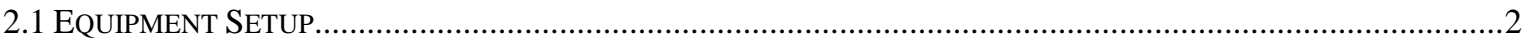

2.2 RECEIPT AND COMBINATION OF SAMPLES FOR THE BLENDED FEED ............................................................

2.3 ChARACTERIZATION OF BlENDED FEED, ConCENTRATE, AND CONDENSATE SAMPLES ...............................

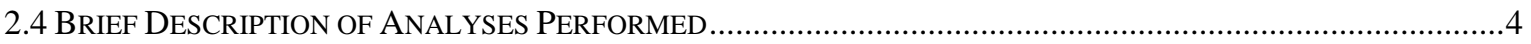

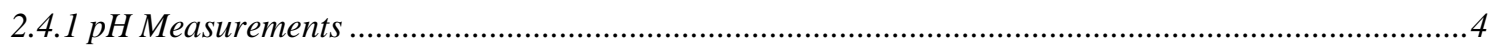

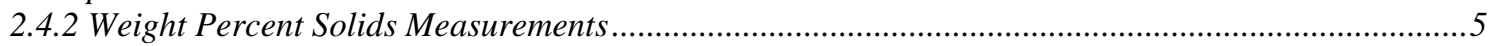

2.4.3 Calculation of Insoluble Solids and Soluble Solids for the Slurry Sample ..........................................

2.4.4 Density Determinations for the Sludge Slurry and Supernate ............................................................

2.4.5 ICP-ES, ICP-MS, Cold Vapor Methods, Gamma Scan, and Liquid Scintillation ................................5

2.4.6 Equivalents per Liter of Base Required to Obtain a pH of 7 ............................................................6

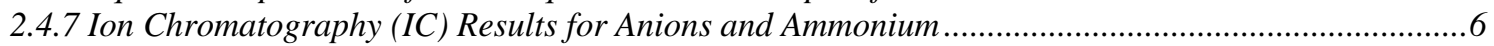

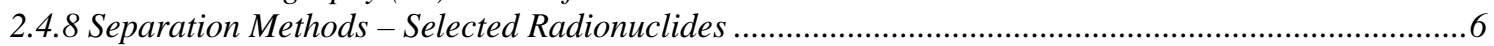

3.0 RESULTS...............................................................................................................................................................



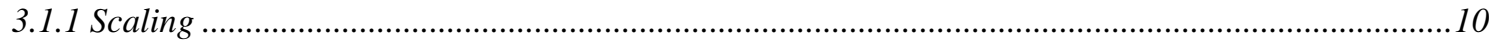

3.1.2 Run Volume Summary ...........................................................................................................11

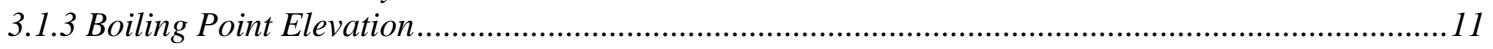

3.2 SAMPLE RESUltS FOR BLENDED FEED, ConCENTRATE, AND CONDENSATE SAMPLES...............................11

3.2.1 Condensate Results Comparison to F/H ETP WAC Limits...........................................................16

3.3 BLENDED FEED COMPARISON TO PREVIOUS SAMPLES ............................................................................19

3.4 COMPARISONS TO SIMULANT EVAPORATOR TESTING AND OLI MODEL RESUlTS .....................................19

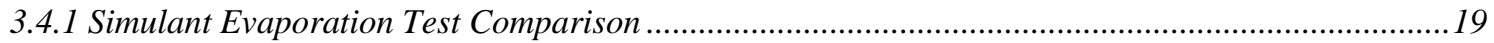

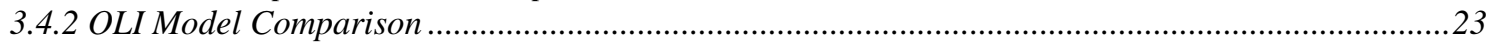

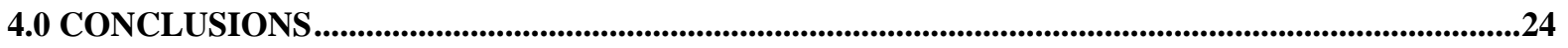

5.0 RECOMMENDATIONS/PATH FORWARD …….............................................................................25

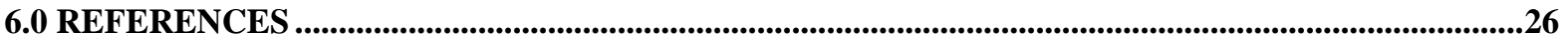

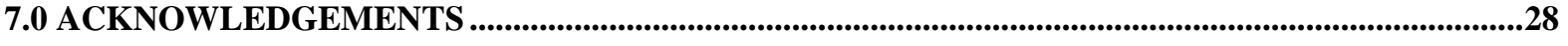

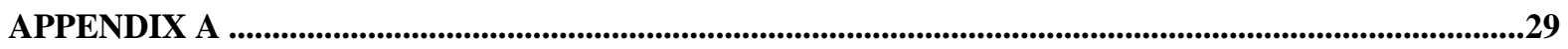

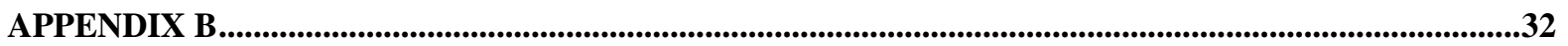

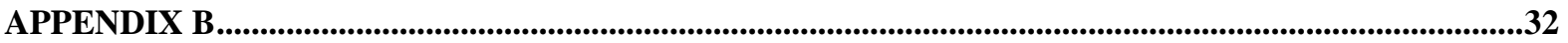




\section{LIST OF FIGURES}

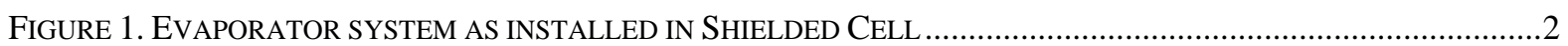

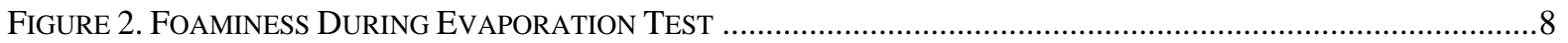

FIGURE 3. EVAPORATOR VESSEL DURING TESTING ……................................................................................

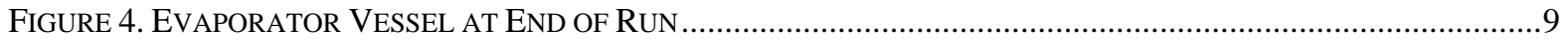



FIGURE 6. THERMOCOUPLE SHOWING NO SCALING OR DEPOSITION.............................................................10

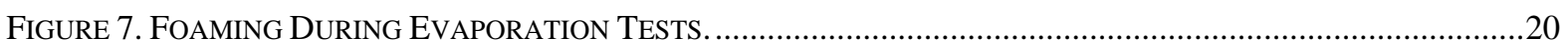

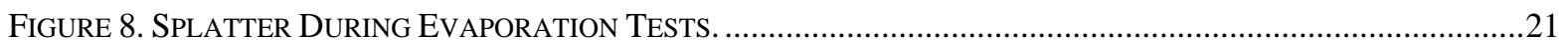

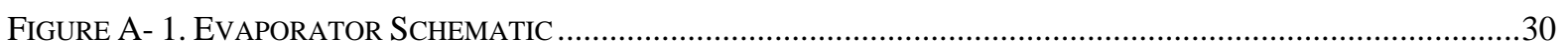

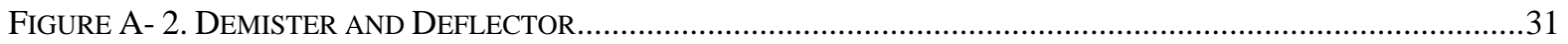

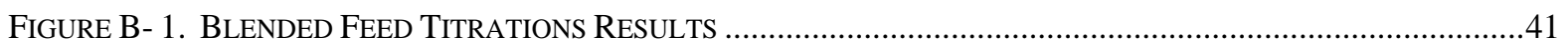

FIGURE B- 2. CONCENTRATE TITRATIONS RESULTS ....................................................................................

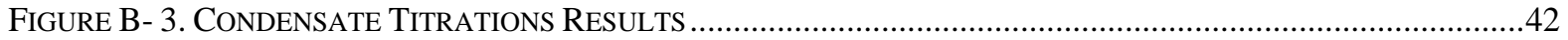

\section{LIST OF TABLES}

TABLE 1. SUMMARY OF ANTIFOAM ADDITIONS AND INTERVALS ……..............................................................

TABLE 2. RUN VOLUMES...........................................................................................................................11

TABLE 3. RESUlTS FOR THE PHYSICAL PROPERTIES AND THE NONRADIOACTIVE ANALYTES ................................12

TABLE 4. MEASURED RESULTS FOR THE RADIOACTIVE ANALYTES .................................................................14

TABle 5. Calculated Activities For Radioactive ANalytes Not MEASURED IN TABLE 4..........................16

TABLE 6. COMPARISON THE CONDENSATE ANALYTES TO THE F/H ETP WAC.....................................................17

TABLE 7. CoMPARISON OF BLENDEd FEEd COMPOSITION TO PREVIOUS SAMPLE RESUlTS ..................................19

TABLE 8. COMPARISON OF CHEMICAL COMPOSITION OF SIMULANT RUNS TO RADIOACTIVE TEST .......................22

TABLE B- 1. BLENDED FEED SAMPLE RESULTS ………..............................................................................3



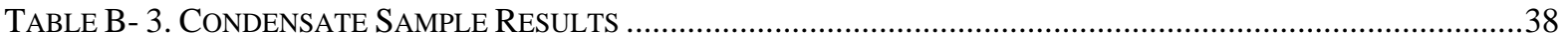

TABle B- 4. ACID EVAPORATOR DEMONSTRATION DF, CF, AND MASS BALANCE RESUlts ................................43 


\section{LIST OF ACRONYMS}

$\begin{array}{ll}\text { ADS } & \text { Analytical Development Section } \\ \text { CF } & \text { Concentration Factor } \\ \text { CPC } & \text { Chemical Processing Cell } \\ \text { DF } & \text { Decontamination Factor } \\ \text { DI } & \text { De-Ionized } \\ \text { DWPF } & \text { Defense Waste Processing Facility } \\ \text { DWTT } & \text { Decontamination Waste Treatment Tank } \\ \text { ETP } & \text { Effluent Treatment Plant } \\ \text { HLW } & \text { High Level Waste } \\ \text { OGCT } & \text { Offgas Condensate Tank } \\ \text { RCT } & \text { Recycle Collection Tank } \\ \text { SB3 } & \text { Sludge Batch Three } \\ \text { SRAT } & \text { Sludge Receipt and Adjustment Tank } \\ \text { SME } & \text { Slurry Mix Evaporator } \\ \text { SMECT } & \text { Slurry Mix Evaporator Condensate Tank } \\ \text { SRNL } & \text { Savannah River National Laboratory } \\ \text { WAC } & \text { Waste Acceptance Criteria }\end{array}$




\subsection{INTRODUCTION AND BACKGROUND}

For every gallon of high level waste sludge processed, DWPF returns approximately 5 gallons of recycle material to the $\mathrm{H}$-Area Tank Farm. Currently this material is processed through the $2 \mathrm{H}$ Evaporator system. The recycle amounts to approximately 1,400,000 gallons per year. This stream is currently the largest volume source of influent to the Tank Farm. The quantity of recycle is expected to more than double with the addition of Salt Processing to the current sludge-only operations.

Tank Farm space limitations and the formation of sodium alumino-silicates in the $2 \mathrm{H}$ evaporator system have led to the evaluation of alternative methods to disposition the recycle stream. Because it is the largest influent stream to the Tank Farm, reducing or redirecting some portion of it would help in the management of HLW tank space. One option identified is the concentration of the recycle streams that would allow the solids to be processed in the SRAT and the condensate processed through the F/H Effluent Treatment Plant (ETP).

Previous work includes a feasibility study ${ }^{1}$, as well as simulant testing ${ }^{2}$ and OLI modeling ${ }^{3}$. The feasibility study concluded that the concentration objectives could be met. This initial study was based on initial estimates of recycle concentration and was based solely on OLI modeling of the evaporation process.

The simulant testing was performed to determine the feasibility and processing characteristics of an evaporation process to reduce the volume of the recycle stream from the DWPF. Various blends of evaporator feed were tested using simulants. The simulated feed was evaporated in a laboratory scale apparatus to a $30 \mathrm{X}$ volume reduction. Condensate samples showed that the condensate has the potential to exceed the ETP WAC for mercury, silicon, and total organic carbon. Foaming was noted during all of the simulant evaporation tests. No scaling on heating surfaces was noted during the tests, but splatter onto the walls of the evaporation vessels led to a buildup of solids.

OLI modeling was performed over a wide range of input compositions and recycle stream blend ratios. The model results indicated that the concentration of the DWPF recycle by 30X was feasible provided the solids content of the evaporator feed was not excessively high. The assumed amounts of entrained solids prevented a significant number of radionuclides from meeting the ETP limits.

The testing reported in this document is intended to build off of the previous work by using actual DWPF recycle material. Processing characteristics are noted and the final products are compared to the WAC limits. Work was performed based on instructions from DWPF Engineering as outlined in a Technical Task Request ${ }^{4}$ and guidelines documented in the Task Technical and Quality Assurance Plan ${ }^{5}$ and Analytical Study Plan ${ }^{6}$. All experimental work was documented in a laboratory notebook ${ }^{7}$. 


\subsection{APPROACH}

\subsection{Equipment Setup}

A laboratory scale evaporator was fabricated as shown in Appendix A. A photograph of the actual assembly used in the testing in the Shielded Cells is shown below as Figure 1. The evaporator test system consists of an evaporation vessel with stir bar, a stirring hotplate, an aluminum heat transfer plate, antifoam addition pipette, air purge with manometer, mist deflector, wire mesh demister, a condenser, and a condensate collection vessel. A feed tank and pump was utilized to feed the evaporator continuously during the run.

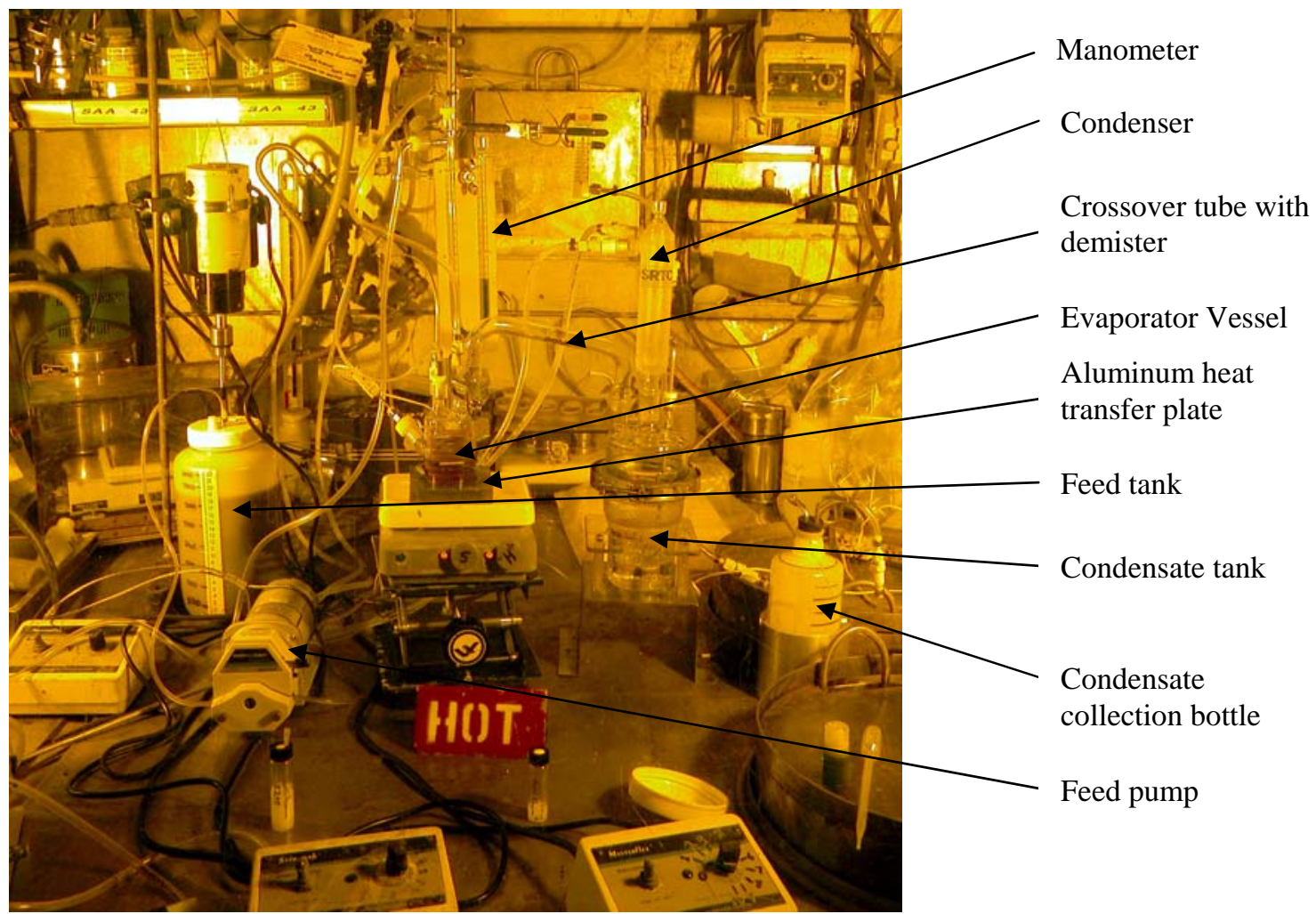

Figure 1. Evaporator system as installed in Shielded Cell

The evaporator vessel is glass vessel with an approximate volume of $250 \mathrm{~mL}$. The process feed level target was $100 \mathrm{~mL}$ during the run. The evaporator vessel was heated by a stirring hot plate. An aluminum block was used to maximize heat transfer from the hot plate to the vessel. The bottom of the vessel was ground flat, also to maximize heat transfer. Temperature was monitored throughout the run by a Type K thermocouple. The vessel was purged with $50 \mathrm{cc} / \mathrm{min}$ of air controlled using a MKS controller. Cooling water for the condenser was provided by the Shielded Cells facility chiller with a set point of $45^{\circ} \mathrm{F}$. The evaporator system was leak checked prior to startup.

During operation, vapors traveled through a steel wire mesh demister and through a crossover tube into the condensate collection vessel. The demister was used to minimize the potential carry over of solids due to splatter during evaporation. In addition, a small deflector was 
positioned to prevent direct splatter into the offgas line. This deflector consisted of a sheet metal circle suspended below the demister pad, as shown in Appendix A. A condenser was placed inline with the exit of the condensate vessel to dry the purge air prior to exiting the system. The condensate collection vessel was a $500 \mathrm{~mL}$ beaker and lid. With a total feed volume of 3000 $\mathrm{mL}$, several transfers had to be made from the condensate collection vessel to bottles. These transfers were accomplished using a siphon system. The siphon was a closed system to minimize the potential for contamination from the cell environment. Transfers were typically made at a condensate level of approximately $300 \mathrm{~mL}$. The transfer dip-leg was approximately 0.25 inches off of the bottom of the collection vessel to minimize the potential for elemental mercury carry-over.

\subsection{Receipt and Combination of Samples for the Blended Feed}

Approximately 1.5 liters of sample ( $125 \mathrm{~mL} /$ per sample) were taken from the SMECT and the OGCT at the DWPF and transported to SRNL to be used for the Acid Evaporator demonstration in the Shielded Cells. Upon receipt, the samples were placed into the Shielded Cells, then mixed, poured, and combined into a calibrated 4-liter bottle. In addition to these samples, previously received SMECT samples ${ }^{8}$, Sludge Batch 3(SB3) SME material ${ }^{9}$, and DI water were added to the 4-liter bottle to meet the volumes specified below:

$\begin{array}{lll}\text { SMECT Volume } & 2016 & \mathrm{~mL} \\ \text { OGCT Volume } & 1721 & \mathrm{~mL} \\ \text { Sample Flush Volume } & 5 & \mathrm{~mL} \text { SB3 SME product } \\ \text { Drains/Cells Sump Volume } & 258 & \mathrm{~mL} \text { (i.e. DI water) } \\ \text { Decon Solution Volume } & 0 & \mathrm{~mL} \\ \text { HEME Dissolution Volume } & 0 & \mathrm{~mL}\end{array}$

The combination of these solutions made up the blended feed that was used for the Acid Evaporator demonstration.

\subsection{Characterization of Blended Feed, Concentrate, and Condensate Samples}

Samples of the blended feed, concentrate, and condensate were analyzed for chemical and radionuclide composition. Since the blended feed and concentrate samples contained visible brown solids, dissolution techniques were required to obtain the chemical composition and radionuclide composition. The solids for the blended feed sample appeared to be made up of a range of particle size from fine to larger particles as seen in previous OGCT samples ${ }^{10}$. The large particles appeared to settle out of the solution rapidly and fine particles settled very slowly. The concentrate samples appeared to be made up of larger particles that settled rapidly. In order to retrieve a representative aliquot of the samples, a mechanical mixer was used to provide homogenous slurry. No dissolution techniques were required for the condensate samples, because the samples were clear and had no visible solids. Samples of the condensate, blended feed slurry, concentrate slurry, filtered supernate of the blended feed and concentrate, and dissolutions solutions for the blended feed and concentrate were submitted for analyses to obtain the following data: 
- $\mathrm{pH}$

- Weight percent total solids

- Weight percent dissolved solids in the supernate (if solids were present)

- Density measurements for slurry (if solids were present) and supernate

- Nonradioactive Analytes (including total U) by Inductively Coupled Plasma Emission Spectroscopy (ICP-ES)

- Fission Products and Actinides (including Co-59) by Inductively Coupled Plasma Mass Spectroscopy (ICP-MS)

- Cold Vapor Hg, K, Se, and As by Atomic Absorption (AA)

- Gamma Scan

- Equivalents of Base required to obtain $\mathrm{pH}$ of 7

- Anions and ammonium by Ion Chromatography (IC)

- Total Carbon (TC), Total Inorganic Carbon (TIC), and Total Organic Carbon (TOC)

- Liquid Scintillation Counting

- Sr-90

- Gamma Scan Cs Removed (Blended Feed only)

- Pm-147/Sm-151 (Blended Feed only)

- Ni-59/Ni-63 (Blended Feed only)

- Am/Cm (Blended Feed only)

- Se-79 (Blended Feed only)

- I-129 (Blended Feed only)

- Tritium (Blended Feed only)

- Pu-238/Pu-241 (Blended Feed only)

- The insoluble and soluble solids (if solids were present) were calculated from the total and dissolved solids measurements.

As a part of this Acid Evaporator demonstration, it was requested that the condensate results be compared to the $\mathrm{F} / \mathrm{H}$ ETP $\mathrm{WAC}^{11}$. The chemical and radionuclide concentrations in the condensate were projected to be very low with the exception of Sr-90, Total Alpha, Total Beta, $\mathrm{Hg}$, and Si based on nonradioactive simulant testing ${ }^{2}$ and OLI modeling ${ }^{3}$. Method detection limits for the analytical instruments, decontamination factors, or a combination of both for the blended feed, concentrate, and condensate were used to project the composition of condensate so that it can be compared to the F/H ETP WAC.

\subsection{Brief Description of Analyses Performed}

\subsection{1 pH Measurements}

To perform the $\mathrm{pH}$ measurements, a portion of each sample was removed and checked with an in-cell pH probe. The probe was first standardized with buffer solutions at a pH of 10 and 7. The probe was then checked with a $\mathrm{pH} 4$ buffer solution. Once the $\mathrm{pH}$ probe had been checked out, the $\mathrm{pH}$ measurement of the samples were completed. After the completion of the sample measurements, the $\mathrm{pH}$ probe was then checked again with the buffer solutions to determine if the $\mathrm{pH}$ probe had drifted away from the initial standardization. 


\subsubsection{Weight Percent Solids Measurements}

To perform the weight percent solids measurement, mixed samples were pipetted out of the appropriate bottles and placed into labeled beakers. These beakers were weighed and then placed into a drying oven at $115^{\circ} \mathrm{C}$ overnight. Samples of a $\mathrm{NaCl}$ solution with a known weight percent total solids were also weighed and dried (in labeled beakers) along with the sludge slurry samples to check the accuracy and precision of the method. All of the samples were removed from the oven and allowed to cool for $\sim 5$ minutes before they were weighed. Once a constant weight was obtained, the measurement was considered complete.

To obtain the supernate for the weight percent solids measurement, a mixed sample of the combined sludge slurry was filtered through a $0.45 \mu$ Nalgene ${ }^{\circledR}$ filter resulting in a clear supernate. The same procedure used for the sludge slurry was followed for the supernate.

\subsubsection{Calculation of Insoluble Solids and Soluble Solids for the Slurry Sample}

Once the average for the total weight percent solids of the sludge slurry and the average weight percent dissolved solids in the supernate values were determined, the soluble and insoluble weight percent solids were calculated. These values were calculated by using the following equations ${ }^{12}$.

Equation 1: $\quad \mathrm{W}_{\mathrm{is}}=\left(\mathrm{W}_{\mathrm{ts}}-\mathrm{W}_{\mathrm{ds}}\right) /\left(1-\mathrm{W}_{\mathrm{ds}}\right) * 100$

Equation 2: $\quad \mathrm{W}_{\mathrm{ss}}=\mathrm{W}_{\mathrm{ts}}-\mathrm{W}_{\text {is }}$

$\mathrm{W}_{\mathrm{ds}}$ - Weight fraction of dissolved solids (weight of dissolved solids/weight of supernate)

$\mathrm{W}_{\mathrm{ts}}$ - Weight fraction of total solids (weight of total solids/weight of sludge slurry)

$\mathrm{W}_{\text {is }}$ - Weight fraction of insoluble solids (weight of insoluble solids/weight of sludge slurry)

$\mathrm{W}_{\mathrm{ss}}$ - Weight fraction of soluble solids (weight dissolved solids/weight of sludge slurry)

\subsubsection{Density Determinations for the Sludge Slurry and Supernate}

Density measurements for the sludge slurry and supernate were completed remotely in the Shielded Cells Facility by using heat sealed pipette tips. The pipette tips were first sealed and then calibrated with water to obtain the volume. After determining the volume, density measurements were completed for the sludge slurry and supernate. The sealed pipette tip was first weighed and then a mixed sample was pipetted into the sealed pipette tip. The sealed pipette tip containing the sample was weighed and a density calculated. The same protocol was used for the supernate samples. The supernate sample was obtained by filtering a portion of the sludge slurry.

\subsubsection{ICP-ES, ICP-MS, Cold Vapor Methods, Gamma Scan, and Liquid Scintillation}

The ICP-ES method provided the data for the nonradioactive analytes plus total U, with the exception of $\mathrm{Hg}$, Se, K, and As, which were measured by AA methods. The ICP-MS method provided the data for fission product and actinide concentrations of the samples. The gamma scan provided the concentrations of the major gamma emitters present in the samples, such as Co-60, Eu-154, etc. The liquid scintillation method provided the total activity for alpha and beta emitters in the sample. 
If the samples contained solids they were dissolved per the dissolution techniques, described in the paragraph below. If the samples had no solids, three portions of the sample were taken and removed from the Shielded Cells and analyzed per the requested methods.

To dissolve the sludge slurry, two portions of a mixed sample were taken and dried overnight in a drying oven at $115^{\circ} \mathrm{C}$. This dried sludge slurry was then dissolved by the Aqua Regia and Peroxide Fusion methods along with appropriate standards and blanks to check the dissolutions and the analytical methods. Typical dissolutions used $0.1 \mathrm{~g}$ of dried solids dissolved in $100 \mathrm{~mL}$ of solution. After performing the dissolution methods on the sludge slurry, a portion of the dissolved samples were removed from the Shielded Cells Facility. These dissolved samples were sent to Analytical Development Section (ADS) Sample Receiving for analyses to be performed by ADS.

\subsubsection{Equivalents per Liter of Base Required to Obtain a pH of $\mathbf{7}$}

To obtain the amount of base required to obtain a $\mathrm{pH}$ of 7 for the samples, titrations are completed on two portions ( 10 g each) of each mixed sample. The first step in the procedure was to weigh each individual portion of the sample. The next step was to add a known volume of $0.1 \mathrm{~N}$ or $1 \mathrm{~N} \mathrm{NaOH}$ to the sample depending on an estimated acid content of the sample. The sample was then mixed, and a $\mathrm{pH}$ recorded once the readout from the $\mathrm{pH}$ probe stabilized. The volume of base was also recorded after each addition to the sample. The titration was considered complete once the $\mathrm{pH}$ of the sample was above $\mathrm{pH}$ of 10 . This procedure was performed on duplicate aliquots of each sample.

\subsubsection{Ion Chromatography (IC) Results for Anions and Ammonium}

If the samples had no solids, two portions of the sample were taken and analyzed per the requested methods. If the samples contained solids, a mixed sample of the slurry was filtered through a $0.45 \mu$ Nalgene ${ }^{\circledR}$ filter resulting in a clear supernate. These samples were diluted, removed, and analyzed per the requested methods.

\subsubsection{Separation Methods - Selected Radionuclides}

Separation methods were used to determine the concentrations of radionuclides that were low in concentration or may have interferences from the activity other radionuclides, such as Cs. A detailed description of each of these separation methods have been documented previously ${ }^{13,14}$.

The Sr-90 method was performed for the blended feed, concentrate and condensate samples. An aliquot of the condensate and the Peroxide Fusion dissolution solutions of the blended feed and concentrate were used for this analysis. For the Ni-59/Ni-63, Se-79, and tritium methods, aliquots of the aqua regia dissolutions of the blended feed were used. For the Pm-147/Sm-151, $\mathrm{Pu}-238 / \mathrm{Pu}-241, \mathrm{Am} / \mathrm{Cm}$, and Gamma Scan Cs Removal, the Peroxide Fusion dissolution solutions of the blended feed were used. For the I-129 method, aliquots of the blended feed slurry were submitted. 


\subsection{RESULTS}

\subsection{Run Performance}

The feed tank was mixed for 30 minutes prior to the start of the run. Approximately $125 \mathrm{~mL}$ of the feed solution was introduced to the evaporator vessel. The magnetic stirring bar and the hot plate were then started. The feed pump was started after the boiling reduced the level within the vessel to approximately $100 \mathrm{~mL}$. The feed rate was targeted for $2.9 \mathrm{~mL}$ per minute ( 8\% of design flux rate), the boil rate from simulant testing, but was altered throughout the run to maintain the $100 \mathrm{~mL}$ evaporator vessel level. Feed rate adjustments were generally very small and feeding was continuous throughout the run with one exception described below. Initial boiling behavior showed the formation of large rapidly bursting bubbles with a maximum width of approximately one inch and height of approximately 3/8ths of an inch ( 25\% foam level). The liquid level was clearly visible in the vessel as these large bubbles were the only indication of foaming.

Approximately three hours into boiling, a split in the feed tubing was detected. Upon the detection of the leak, feeding was halted, heat was reduced and a replacement feed tube was fabricated and installed. During the time required for the repair, the level in the evaporator vessel dropped from the target $100 \mathrm{~mL}$ to approximately $50 \mathrm{~mL}$. With the feed tube repaired, the feed rate was increased to restore the level in the evaporator. The behavior of the bubbles after this incident changed to a larger concentration of smaller bubbles. The smaller bubbles were typical throughout the remainder of the run.

As boiling and the resulting concentration continued, a layer of foam started forming. After several hours of concentration, some level surging was observed in the foam layer. Foam height would increase approximately 25 percent over a period of a few seconds and then recede in the same time frame. As the level of foaming rose to between 75 and 100 percent over the feed volume, 100ppm of Dow Corning 2210 antifoam was added. Antifoam was injected into the vessel by a needle through a septum so that the system remained closed during antifoam addition. The first addition was added approximately 5 hours after the start of the run. The foaming levels dropped rapidly after the antifoam addition.

A total of seven antifoam additions of $100 \mathrm{ppm}$ were made throughout the run. Table 1 shows the intervals of the foam additions as well as the amount of feed.

Table 1. Summary of antifoam additions and intervals

\begin{tabular}{|c|c|c|c|c|}
\hline $\begin{array}{c}\text { Antifoam } \\
\text { addition }\end{array}$ & $\begin{array}{c}\text { Antifoam Addition } \\
\text { Run Time } \\
\text { H:MM }\end{array}$ & $\begin{array}{c}\text { Antifoam Addition } \\
\text { Interval } \\
\text { H:MM }\end{array}$ & $\begin{array}{c}\text { Feed tank level } \\
\text { (mL) (initial } \\
\text { level 3400 mL) }\end{array}$ & $\begin{array}{c}\text { Feed volume } \\
\text { fed prior to } \\
\text { addition (mL) }\end{array}$ \\
\hline 1 & $5: 15$ & - & 2699 & 701 \\
\hline 2 & $8: 40$ & $3: 25$ & 2093 & 606 \\
\hline 3 & $11: 12$ & $2: 47$ & 609 & 484 \\
\hline 4 & $14: 30$ & $3: 18$ & 951 & 758 \\
\hline 5 & $14: 35$ & $0: 05$ & 951 & 0 \\
\hline 6 & $16: 05$ & $1: 30$ & 692 & 259 \\
\hline 7 & $17: 05$ & $1: 00$ & 484 & 208 \\
\hline
\end{tabular}


Figure 2 shows the percent foaminess (ratio of foam volume to solution volume) as a function of run time. Some amount of scatter is seen in the data, mainly due to the difficulty in determining the boundary between foam and the solution in the evaporator. The effectiveness of the Dow Corning antifoam during the initial stages of operation is shown by the drop in foaminess after the first antifoam addition at a run time of 330 minutes. The antifoam performance slowly degraded over a period of 200 minutes and additional antifoam was added. The effectiveness of the second addition was less than the first antifoam addition, a trend that can be seen for subsequent additions. As the feed reached the final concentration, the $100 \mathrm{ppm}$ additions of the Dow Corning 2210 was much less effective and the degradation in performance occurred much faster than during initial stages of the run. The lack of effectiveness may point to a need for larger antifoam additions as the solids content of the evaporator liquor increases. Additional tests with simulants should be utilized to optimize the antifoam type and addition strategy.

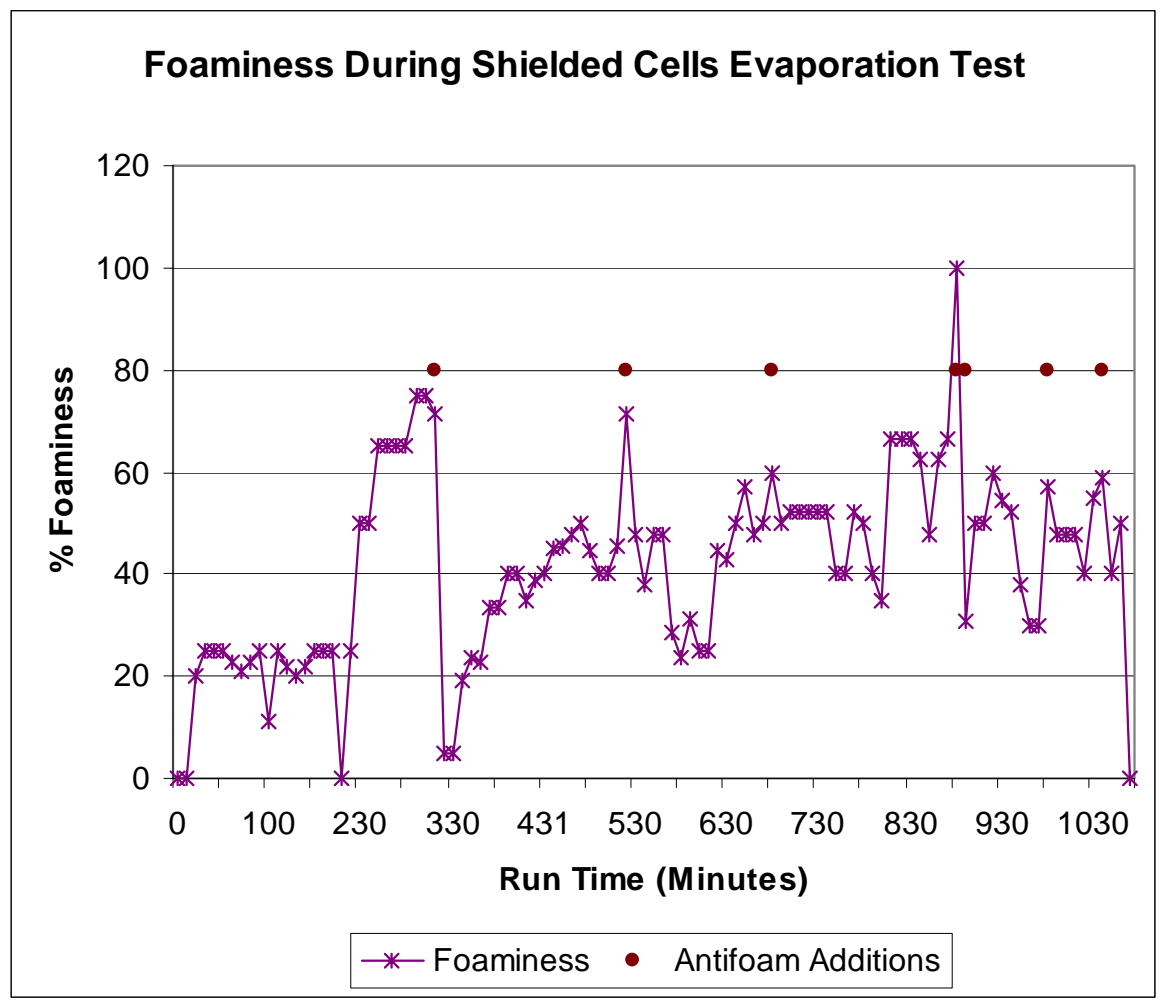

Figure 2. Foaminess During Evaporation Test

Figure 3 shows a photo of the evaporator vessel during the run. The white line marks the 100 $\mathrm{mL}$ level in the vessel. The top of the vessel shows signs of splatter during the evaporation. The clean glass between the foam and the wall splatter indicates the approximate foam height prior to an antifoam addition. 


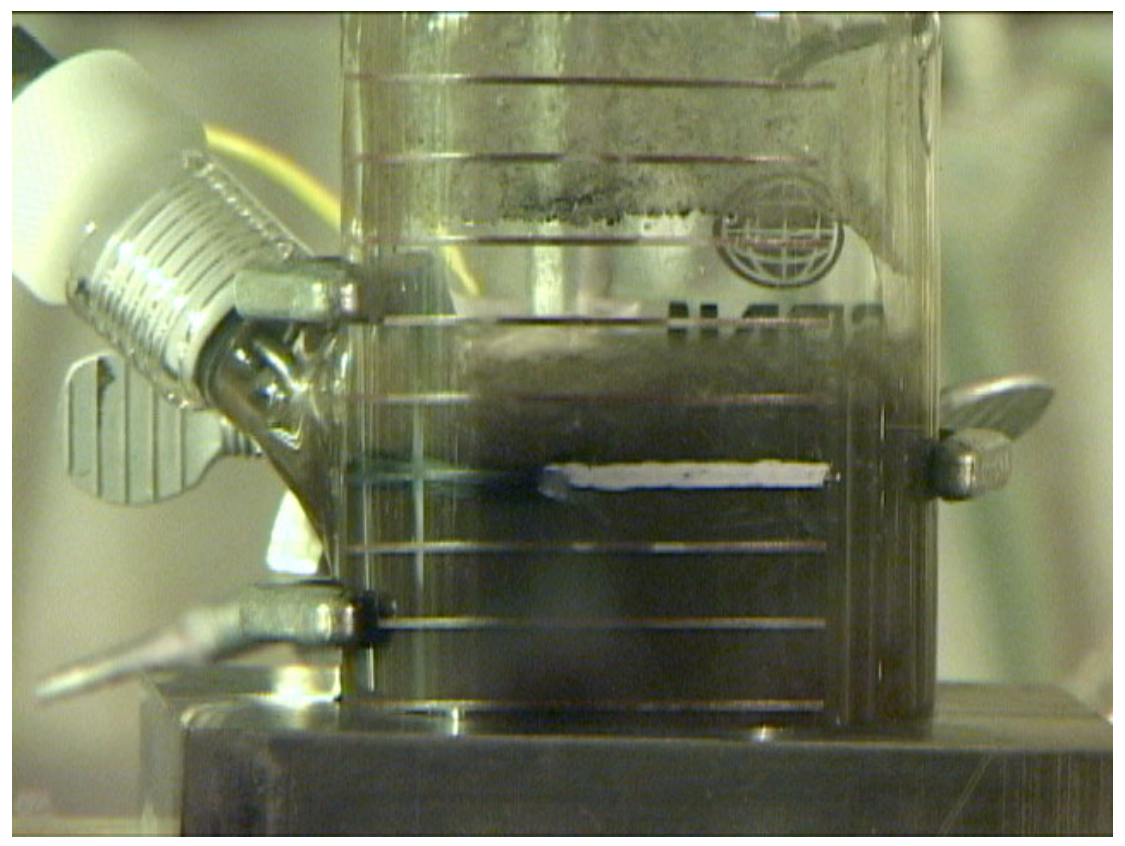

Figure 3. Evaporator Vessel During Testing

A total of $3000 \mathrm{~mL}$ of feed was fed to the vessel and concentrated to a final volume of approximately $90 \mathrm{~mL}$ at the time the heat was removed. When the vessel was inspected the next morning, the level in the vessel dropped to approximately $80 \mathrm{~mL}$ due to continued evaporation from residual heat. During transfer of the concentrate to the samples bottles the vessel was rinsed with DI water. The rinse water increased the final concentrate volume to approximately $100 \mathrm{~mL}$. Figure 4 and Figure 5 show the vessel at the time the run was completed and the following morning respectively.

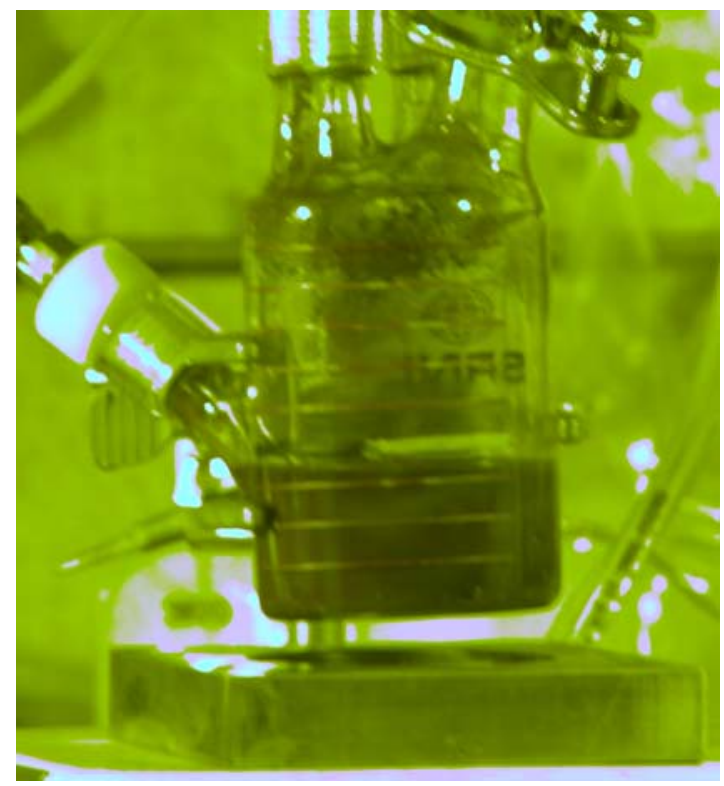

Figure 4. Evaporator Vessel at End of Run 
WSRC-TR-2005-00309

Revision 0

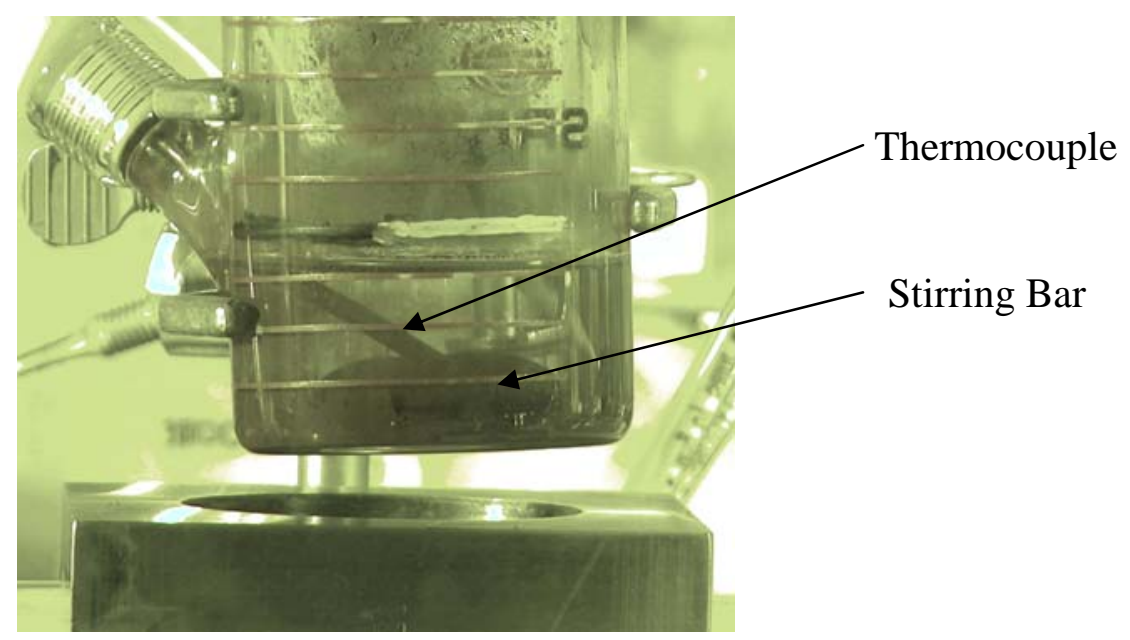

Figure 5. Evaporator Vessel Next Morning

It was also observed that the final concentrate settled leaving a clear supernate. The thermocouple and magnetic stirring bar are clearly seen in the vessel. The elapsed time between the two photos was approximately 7 hours. The final concentrate displayed more rapid settling that the initial feed solution. It should be noted that flocculation was observed during simulant testing with the addition of Dow Corning 2210 antifoam $^{2}$. If flocculation due to the antifoam addition occurred during the radioactive test, the settling behavior would have been impacted in the manner seen during the test.

\subsubsection{Scaling}

No buildup off solids was noted on the heated glass surface, thermocouple, or stir bar. The apparent coating of solids on the thermocouple visible in Figure 5 was a layer of solids from settling. The vessel was easily cleaned by rinsing with a small amount of DI water. The thermocouple was easily cleaned by wiping with a clean towel. No evidence of scaling or residue was found as can be seen in Figure 6: a photo of the thermocouple after being wiped off after disassembly of the evaporator vessel.

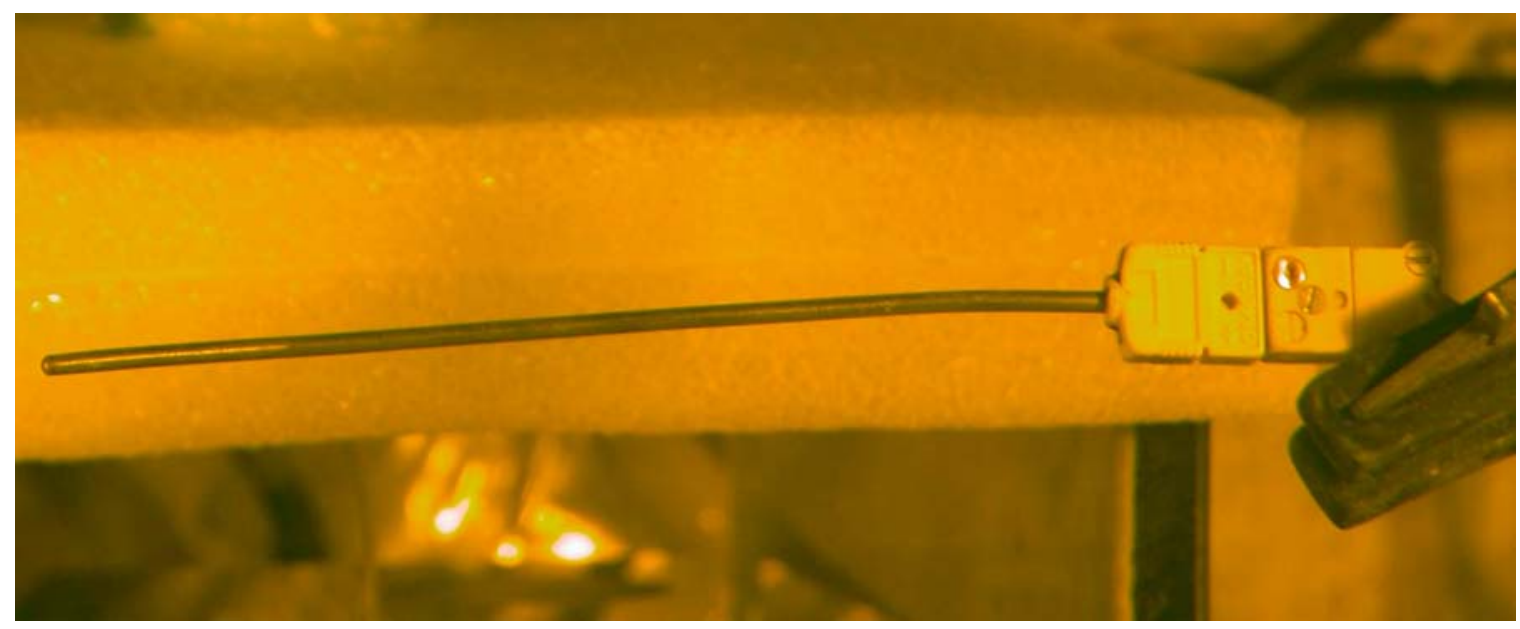

Figure 6. Thermocouple Showing No Scaling or Deposition 


\subsubsection{Run Volume Summary}

A summary of the run volumes is shown in Table 2.

Table 2. Run Volumes

\begin{tabular}{|c|c|}
\hline Total Feed fed to Evaporator & $3000 \mathrm{~mL}$ \\
\hline Condensate collected & $2765 \mathrm{~mL}$ \\
\hline Condensate in collection vessel at end of run & $35 \mathrm{~mL}$ \\
\hline Concentrate & $90 \mathrm{~mL}$ \\
\hline Discrepancy & $110 \mathrm{~mL}$ \\
\hline
\end{tabular}

All of the volumes listed above were estimated based on visual volumes recorded during the evaporation test. The discrepancy in the volume balance was due to the uncertainty of the estimations as well as some of the vapors not being condensed and escaping from the offgas system. The volumes above did not take into account the material lost when the feed tube ruptured, but the volume lost during this period was very small.

\subsubsection{Boiling Point Elevation}

The temperature of the boiling liquor was monitored during the run to determine the amount of boiling point elevation observed. Initial temperature of the boiling liquor was measured at $100.1^{\circ}$ Celsius. The temperature of the liquor increased steadily during the run and had a final value of $101.8^{\circ}$ Celsius, for a boiling point elevation of $1.7^{\circ}$ Celsius during the run.

\subsection{Sample Results for Blended Feed, Concentrate, and Condensate Samples}

Analyses of the blended feed, concentrate and condensate were performed after the completion of the evaporator run per the Analytical Study Plan ${ }^{6}$. Table 3 provides a summary of the physical properties and the nonradioactive analytes collected for the blended feed, concentrate, and condensate samples. Table 4 presents results for the radioactive analytes. Unless otherwise denoted in Table 3 or Table 4, the values presented are the average of two values. Appendix B contains tables with the averages, standard deviations and percent relative standard deviations for the blended feed, concentrate and condensate data presented in Table 3 and Table 4. Appendix B also contains the titration curves for the blended feed, concentrate, and condensate samples and the mass balance with calculated Concentration Factors (CF) for the blended feed and concentrate and DFs for the blended feed and the condensate. 
Table 3. Results for the Physical Properties and the Nonradioactive Analytes

\begin{tabular}{|c|c|c|c|c|}
\hline Category & Analyte & $\begin{array}{l}\text { Blended Feed } \\
\text { Average }\end{array}$ & $\begin{array}{c}\text { Concentrate } \\
\text { Average }\end{array}$ & $\begin{array}{c}\text { Condensate } \\
\text { Average }\end{array}$ \\
\hline \multirow{6}{*}{ Wt.\% Solids and Density } & Wt.\% Solids of Supernate & N.D. $^{a}$ & 3.84 & N.D. ${ }^{a}$ \\
\hline & Wt. \% Total Solids of Slurry & $2.14 \mathrm{E}-01$ & 5.01 & N.D. $^{a}$ \\
\hline & Wt.\% Insoluble Solids & $2.14 \mathrm{E}-01$ & 1.22 & - \\
\hline & Wt.\% Soluble Solids & N.D. ${ }^{a}$ & 3.93 & - \\
\hline & Slurry Density, g/mL & 1.01 & 1.08 & - \\
\hline & Supernate Density, g/mL & 1.01 & 1.05 & 1.01 \\
\hline \multirow[t]{3}{*}{ Wet Chem } & Total Carbon, mg/L & $7.70 \mathrm{E}+01$ & $4.73 \mathrm{E}+02$ & $6.86 \mathrm{E}+01$ \\
\hline & Total Organic Carbon, mg/L & $7.70 \mathrm{E}+01$ & $4.73 \mathrm{E}+02$ & $6.86 \mathrm{E}+01$ \\
\hline & $\begin{array}{l}\text { Total Inorganic Carbon (i.e. } \\
\text { Carbonate), mg/L }\end{array}$ & $<1 \mathrm{E}+01$ & $<3 \mathrm{E}+02$ & $<1 \mathrm{E}+01$ \\
\hline \multirow[t]{2}{*}{ Titration } & $\begin{array}{l}\text { Equivalents per Liter Required for } \\
\mathrm{pH}=7\end{array}$ & 2.85E-02 & $6.88 \mathrm{E}-01$ & 6.45E-03 \\
\hline & $\mathrm{pH}$ & 2.0 & 1.0 & 3.2 \\
\hline \multirow[t]{9}{*}{$\begin{array}{l}\text { IC Cation and Anions } \\
\text { (mg/L of supernate) }\end{array}$} & Chloride & $4.00 \mathrm{E}+00$ & $<6 \mathrm{E}+01$ & $<3 \mathrm{E}+00$ \\
\hline & Fluoride & $4.00 \mathrm{E}+00$ & $9.51 \mathrm{E}+01$ & $<3 \mathrm{E}+00$ \\
\hline & Nitrate & $1.82 \mathrm{E}+03$ & $5.71 \mathrm{E}+04$ & $4.85 \mathrm{E}+01$ \\
\hline & Nitrite & $<1 \mathrm{E}+01$ & $<3 \mathrm{E}+02$ & $<1 \mathrm{E}+01$ \\
\hline & Oxalate & $<1 \mathrm{E}+01$ & $<3 \mathrm{E}+02$ & $<1 \mathrm{E}+01$ \\
\hline & Phosphate & $<1 \mathrm{E}+01$ & $<3 \mathrm{E}+02$ & $<1 \mathrm{E}+01$ \\
\hline & Sulfate & $2.65 \mathrm{E}+01$ & $6.03 \mathrm{E}+02$ & $5.00 \mathrm{E}+00$ \\
\hline & Ammonium & $<1 \mathrm{E}+01$ & $<3 \mathrm{E}+03$ & $<1 \mathrm{E}+01$ \\
\hline & Formate & $1.95 \mathrm{E}+02$ & $3.49 \mathrm{E}+02$ & $1.66 \mathrm{E}+02$ \\
\hline \multirow[t]{24}{*}{$\begin{array}{l}\text { ICP-ES and AA Results } \\
(\mathrm{mg} / \mathrm{L})\end{array}$} & Ag & 3.23E-01 & $9.62 \mathrm{E}+00$ & $<1 \mathrm{E}-02$ \\
\hline & $\mathrm{Al}$ & $6.10 \mathrm{E}+01$ & $1.34 \mathrm{E}+03$ & $1.61 \mathrm{E}-01$ \\
\hline & $\mathrm{As}^{\mathrm{b}}$ & 4.95E-02 & $1.11 \mathrm{E}+00^{\mathrm{d}}$ & $<3 \mathrm{E}-02$ \\
\hline & B & $2.57 \mathrm{E}+00$ & $7.85 \mathrm{E}+01$ & $1.40 \mathrm{E}-01$ \\
\hline & $\mathrm{Ba}$ & 7.81E-01 & $1.79 \mathrm{E}+01$ & $<3 \mathrm{E}-02$ \\
\hline & $\mathrm{Be}$ & 3.62E-03 & 6.52E-02 & $<2 \mathrm{E}-03$ \\
\hline & $\mathrm{Ca}$ & $9.09 \mathrm{E}+00$ & $2.75 \mathrm{E}+02$ & 8.25E-02 \\
\hline & $\mathrm{Cd}$ & $5.97 \mathrm{E}+00$ & $1.59 \mathrm{E}+02$ & $<5 \mathrm{E}-03$ \\
\hline & $\mathrm{Ce}$ & $1.32 \mathrm{E}+00$ & $2.82 \mathrm{E}+01$ & $<2 \mathrm{E}-01$ \\
\hline & $\mathrm{Cr}$ & $1.55 \mathrm{E}+00$ & $3.10 \mathrm{E}+01$ & $<3 \mathrm{E}-02$ \\
\hline & $\mathrm{Cu}$ & $9.14 \mathrm{E}-01$ & $2.76 \mathrm{E}+01$ & $<1 \mathrm{E}-02$ \\
\hline & $\mathrm{Fe}$ & $4.70 \mathrm{E}+02$ & $1.03 \mathrm{E}+04$ & 2.95E-02 \\
\hline & Gd & 4.86E-01 & $1.27 \mathrm{E}+01$ & $<2 \mathrm{E}-02$ \\
\hline & $\mathrm{Hg}^{\mathrm{b}}$ & $<1 \mathrm{E}-01$ & $2.99 \mathrm{E}+00$ & $3.30 \mathrm{E}+00$ \\
\hline & $\mathrm{K}^{\mathrm{b}}$ & 4.12E-01 & $1.30 \mathrm{E}+01$ & $<2 \mathrm{E}-01$ \\
\hline & $\mathrm{Li}$ & $3.46 \mathrm{E}+00$ & 7.97E+01 & $<5 \mathrm{E}-02$ \\
\hline & $\mathrm{Mg}$ & $2.89 \mathrm{E}+01$ & $6.82 \mathrm{E}+02$ & $<4 \mathrm{E}-03$ \\
\hline & $\mathrm{Mn}$ & $7.23 \mathrm{E}+01$ & $1.75 \mathrm{E}+03$ & $<2 \mathrm{E}-03$ \\
\hline & Mo & $1.30 \mathrm{E}+00$ & $2.54 \mathrm{E}+01$ & $<2 \mathrm{E}-01$ \\
\hline & $\mathrm{Na}$ & $7.71 \mathrm{E}+01$ & $2.28 \mathrm{E}+03$ & $<4 \mathrm{E}-01$ \\
\hline & $\mathrm{Ni}$ & $2.78 \mathrm{E}+01$ & $6.11 \mathrm{E}+02$ & $<4 \mathrm{E}-02$ \\
\hline & $\mathrm{P}$ & $5.87 \mathrm{E}+00$ & $1.36 \mathrm{E}+02$ & 6.02E-01 \\
\hline & $\mathrm{Pb}$ & $8.71 \mathrm{E}-01$ & $2.35 \mathrm{E}+01$ & $<8 \mathrm{E}-01$ \\
\hline & $\mathrm{S}$ & $8.42 \mathrm{E}+00$ & $2.46 \mathrm{E}+02$ & 2.82E-01 \\
\hline
\end{tabular}


WSRC-TR-2005-00309

Revision 0

\begin{tabular}{|c|c|c|c|c|}
\hline Category & Analyte & $\begin{array}{c}\text { Blended Feed } \\
\text { Average }\end{array}$ & $\begin{array}{c}\text { Concentrate } \\
\text { Average }\end{array}$ & $\begin{array}{c}\text { Condensate } \\
\text { Average }\end{array}$ \\
\hline & $\mathrm{Sb}$ & $1.59 \mathrm{E}+00$ & $3.41 \mathrm{E}+01$ & $<1 \mathrm{E}-01$ \\
\hline & $\mathrm{Se}^{\mathrm{b}}$ & $<5 \mathrm{E}-02$ & $1.20 \mathrm{E}+00$ & $<6 \mathrm{E}-02$ \\
\hline & $\mathrm{Si}^{\mathrm{c}}$ & $1.81 \mathrm{E}+02$ & $1.76 \mathrm{E}+03$ & $1.10 \mathrm{E}+01$ \\
\hline & $\mathrm{Sn}$ & $2.41 \mathrm{E}+00$ & $4.93 \mathrm{E}+01$ & $<3 \mathrm{E}-01$ \\
\hline & $\mathrm{Sr}$ & $2.00 \mathrm{E}+00$ & $5.98 \mathrm{E}+01$ & $<1 \mathrm{E}-02$ \\
\hline & $\mathrm{Ti}$ & $4.17 \mathrm{E}-01$ & $9.77 \mathrm{E}+00$ & $<3 \mathrm{E}-03$ \\
\hline & $\mathrm{U}$ & $3.35 \mathrm{E}+01$ & $1.13 \mathrm{E}+03$ & $<2 \mathrm{E}-01$ \\
\hline & $\mathrm{V}$ & $<2 \mathrm{E}-02$ & $5.99 \mathrm{E}+00$ & $2.20 \mathrm{E}-02$ \\
\hline & $\mathrm{Zn}$ & $9.69 \mathrm{E}-01$ & $2.44 \mathrm{E}+01$ & $7.60 \mathrm{E}-02$ \\
\hline & $\mathrm{Zr}$ & $1.79 \mathrm{E}+00$ & $3.26 \mathrm{E}+01$ & $<9 \mathrm{E}-03$ \\
\hline
\end{tabular}

N.D. - Not Detected

N.M. - Not Measured

a Three measurements were completed. The results indicate that there were no solids per a three place balance

${ }^{\mathrm{b}}$ AA Results - As, CV Hg, K, and Se

${ }^{\mathrm{c}}$ Peroxide Fusion results

${ }^{\mathrm{d}}$ One value

Based on previous analyses of the individual tanks that make up the blended feed ${ }^{13}$, the nonradioactive composition is indicative of a sludge distribution with a contribution from the frit components ( $\mathrm{Si}, \mathrm{B}, \mathrm{Li}$, and $\mathrm{Na}$ ) and the antifoam that is added during SRAT/SME processing. Fe appears to be the dominant component followed by Si, Na, Mn, Al, and U. No measurable solids were detected for the supernate and the concentration of the nitrate present in the supernate correlates to $\sim 0.02 \mathrm{~N}$ nitric acid solution which was in agreement with the $\mathrm{pH}$ of the sample.

The Fe appears to be the dominant component in the concentrate followed by $\mathrm{Na}$. This composition was different from the blended feed, which had Si as the next highest component. The concentration of the nitrate present in the supernate indicates that this was a concentrated nitric solution. The $\mathrm{pH}$ determinations completed for the concentrate do not agree with the nitrate or the equivalents of base determined for this sample. This was probably due to operating the $\mathrm{pH}$ probe at the lower end of its operating region. The $\mathrm{pH}$ probe check out with the buffer solution prior to and after sample measurement indicated no issues.

There were no measurable or visible solids detected for the condensate sample using a three place balance. The concentration of the nitrate present in the condensate indicates that this is a dilute nitric acid solution that correlates to $\sim 0.0008 \mathrm{~N}$ nitric acid solution which is in agreement with the $\mathrm{pH}$ of the sample. As can be seen in column 5 of Table 3 , the major components of the condensate are $\mathrm{Si}, \mathrm{Hg}, \mathrm{P}, \mathrm{S}, \mathrm{Al}$, and $\mathrm{B}$ with minor contributions from $\mathrm{Ca}$ and $\mathrm{Fe}$. 
Table 4. Measured Results for the Radioactive Analytes

\begin{tabular}{|c|c|c|c|c|}
\hline Category & Analyte & $\begin{array}{c}\text { Blended Feed } \\
\text { Average }\end{array}$ & $\begin{array}{l}\text { Concentrate } \\
\text { Average }\end{array}$ & $\begin{array}{c}\text { Condensate } \\
\text { Average }\end{array}$ \\
\hline \multirow[t]{6}{*}{ ICP-MS (mg/L) } & Co-59 & 1.79E-01 & $3.89 \mathrm{E}+00$ & $<2 \mathrm{E}-05$ \\
\hline & La-139 & $2.98 \mathrm{E}-01$ & $7.30 \mathrm{E}+00$ & $<2 \mathrm{E}-05$ \\
\hline & $\mathrm{Ru}^{\mathrm{a}}$ & 7.71E-01 & $1.85 \mathrm{E}+01$ & $<9 \mathrm{E}-04$ \\
\hline & Rh-103 & 1.48E-01 & $3.40 \mathrm{E}+00$ & $<5 \mathrm{E}-06$ \\
\hline & $\mathrm{Pd}^{\mathrm{a}}$ & $2.88 \mathrm{E}-02$ & $6.83 \mathrm{E}-01$ & $<2 \mathrm{E}-05$ \\
\hline & $\mathrm{Ag}^{\mathrm{a}}$ & $3.16 \mathrm{E}-01$ & $1.04 \mathrm{E}+01$ & $<4 \mathrm{E}-04$ \\
\hline \multirow[t]{41}{*}{ Counting and ICP-MS (d/m/mL) } & Alpha & $4.95 \mathrm{E}+05$ & $1.61 \mathrm{E}+07$ & $<4 \mathrm{E}+01$ \\
\hline & Beta & $2.04 \mathrm{E}+07$ & $6.16 \mathrm{E}+08$ & $1.55 \mathrm{E}+03$ \\
\hline & H-3 & $<6 \mathrm{E}+02$ & N.M. & N.M. ${ }^{b}$ \\
\hline & $\mathrm{C}-14$ & N.M. & N.M. & N.M. \\
\hline & Al-26 & $<9 \mathrm{E}+00$ & $<8.7 \mathrm{E}+03$ & $<3 \mathrm{E}-01$ \\
\hline & Ni-59 & $3.65 \mathrm{E}+03$ & N.M. & N.M. ${ }^{b}$ \\
\hline & Ni-63 & $4.02 \mathrm{E}+05$ & N.M. ${ }^{b}$ & N.M. ${ }^{b}$ \\
\hline & Co-60 & $7.93 \mathrm{E}+03$ & $1.95 \mathrm{E}+05$ & 2.97E-01 \\
\hline & Se-79 & $1.80 \mathrm{E}+02^{\mathrm{c}}$ & N.M. ${ }^{b}$ & N.M. ${ }^{b}$ \\
\hline & Sr-90 & $7.96 \mathrm{E}+06$ & $2.22 \mathrm{E}+08$ & $<2 \mathrm{E}+03$ \\
\hline & Nb-94 & $<4 \mathrm{E}+01$ & $<2.9 \mathrm{E}+04$ & $<3 \mathrm{E}-01$ \\
\hline & Tc-99 & $1.57 \mathrm{E}+03$ & $3.87 \mathrm{E}+04$ & $<7 \mathrm{E}+00$ \\
\hline & Ru-106 & $<3 \mathrm{E}+02$ & $<3.5 \mathrm{E}+05$ & $<2 \mathrm{E}+00$ \\
\hline & Sb-125 & $5.24 \mathrm{E}+02$ & N.M. ${ }^{b}$ & N.M. ${ }^{b}$ \\
\hline & Sn-126 & $<4 \mathrm{E}+01$ & $<3.7 \mathrm{E}+04$ & $<8 \mathrm{E}-01$ \\
\hline & Sb-126 & $<4 \mathrm{E}+01$ & $<3.7 \mathrm{E}+04$ & $<3 \mathrm{E}-01$ \\
\hline & I-129 & $7.35 \mathrm{E}+00$ & N.M. ${ }^{b}$ & N.M. ${ }^{b}$ \\
\hline & Cs-134 & $<1 \mathrm{E}+02$ & $<3.3 \mathrm{E}+04$ & $<3 \mathrm{E}-01$ \\
\hline & Cs-135 & N.M. ${ }^{b}$ & N.M. ${ }^{b}$ & N.M. ${ }^{b}$ \\
\hline & Cs-137 & $5.77 \mathrm{E}+05$ & $1.97 \mathrm{E}+07$ & $3.90 \mathrm{E}+01$ \\
\hline & Pm-147 & $3.90 \mathrm{E}+05$ & N.M. & N.M. \\
\hline & Sm-151 & $2.98 \mathrm{E}+05^{\mathrm{d}}$ & $1.18 \mathrm{E}+07^{\mathrm{e}}$ & $<3 \mathrm{E}+02^{\mathrm{e}}$ \\
\hline & Eu-154 & $1.57 \mathrm{E}+04$ & $5.16 \mathrm{E}+05$ & $6.48 \mathrm{E}-01$ \\
\hline & Eu-155 & $7.19 \mathrm{E}+03$ & $<1.9 \mathrm{E}+05$ & $<1 \mathrm{E} 00$ \\
\hline & Ra-226 & $<1.4 \mathrm{E}+03$ & $<1.4 \mathrm{E}+06$ & $<6 \mathrm{E}+00$ \\
\hline & Th-230 & $4.36 \mathrm{E}-01$ & $5.09 \mathrm{E}+00$ & $<2 \mathrm{E}-01$ \\
\hline & Th-232 & 1.39E-01 & $3.50 \mathrm{E}+00$ & $<5 \mathrm{E}-06$ \\
\hline & U-233 & $1.04 \mathrm{E}+01^{\mathrm{c}}$ & $7.01 \mathrm{E}+00$ & $<3 \mathrm{E}-01$ \\
\hline & U-234 & $2.82 \mathrm{E}+01$ & $1.03 \mathrm{E}+03$ & $<1 \mathrm{E}-01$ \\
\hline & U-235 & $8.40 \mathrm{E}-01$ & $3.22 \mathrm{E}+01$ & $<5 \mathrm{E}-05$ \\
\hline & U-236 & 7.53E-01 & $3.12 \mathrm{E}+01$ & $<7 \mathrm{E}-04$ \\
\hline & U-238 & $2.44 \mathrm{E}+01$ & $8.30 \mathrm{E}+02$ & $1.72 \mathrm{E}-03$ \\
\hline & Np-237 & $5.44 \mathrm{E}+01$ & $2.05 \mathrm{E}+03$ & $<8 \mathrm{E}-03$ \\
\hline & Pu-238 & $1.07 \mathrm{E}+05$ & N.M. ${ }^{b}$ & N.M. ${ }^{b}$ \\
\hline & Pu-239 & $5.12 \mathrm{E}+04$ & $1.62 \mathrm{E}+06$ & $<7 \mathrm{E}-01$ \\
\hline & $\mathrm{Pu}-240$ & $1.75 \mathrm{E}+04$ & $5.49 \mathrm{E}+05$ & $<5 \mathrm{E}+00$ \\
\hline & Pu-241 & $2.29 \mathrm{E}+05$ & N.M. ${ }^{b}$ & N.M. ${ }^{b}$ \\
\hline & Pu-242 & $1.30 \mathrm{E}+01$ & $4.04 \mathrm{E}+02$ & $<1 \mathrm{E}-01$ \\
\hline & Am-241 & $5.04 \mathrm{E}+04$ & $1.46 \mathrm{E}+06$ & $<2 \mathrm{E}+00$ \\
\hline & Am-243 & $3.61 \mathrm{E}+03$ & $1.17 \mathrm{E}+05$ & $<4 \mathrm{E}+00$ \\
\hline & Cm-244 & $2.29 E+05$ & $9.47 E+06$ & $<9 \mathrm{E}+02$ \\
\hline
\end{tabular}

N.M. - not measured 


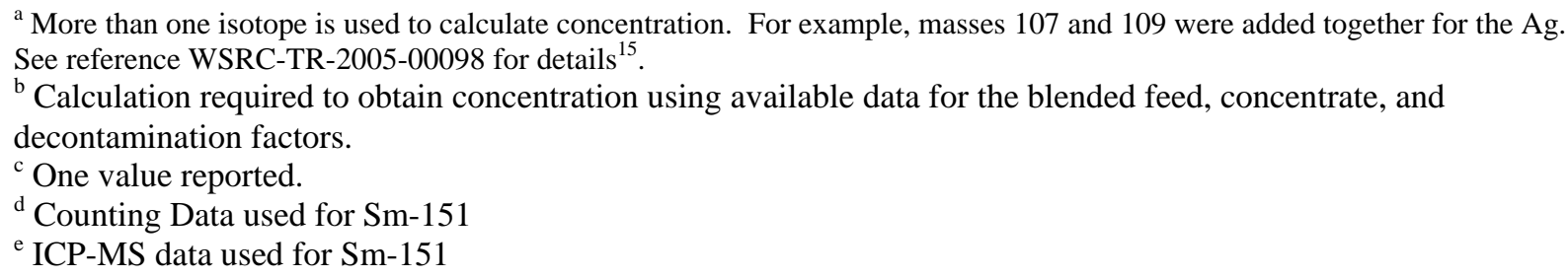

The data for the concentrate confirmed that the blended feed was concentrated by a factor of approximately $27.5 \pm 7.1$. This factor was obtained by taking the concentration of the analytes in the concentrate and dividing it by the concentration of the same analyte in the blended feed using columns 3 and 4 of Table 3 and Table 4 . The ratios of the analytes were then averaged for all the analytes with the exception of ratios for ammonium, formate, silica, vanadium, Al-26, Nb-94, Ru-106, Sb-126, Sn-126, Cs-134, Eu-155 and Ra-226. A table containing the calculated concentration factors can be found in Appendix B (Table B-4, last column). The ratios for the vanadium, ammonium, Al-26, Nb-94, Ru-106, Sb-126, Sn-126, Cs-134, Eu-155 and Ra-226 were not used because the ratios were high. The high ratios were due to using the detection limits of instruments to determine the concentration factor. The ratios for the formate and the silica were below 10 . These concentrations were above the detection limit of the instrument and the replicates had good agreement, so the analyses appear to be accurate. These ratios were expected based on the chemistry of these components in low $\mathrm{pH}$ solutions, and they also confirm earlier results obtained during simulant testing ${ }^{2}$. The ratio for Si also agrees with the change seen in the composition of the concentrate.

Decontamination factors (DF) were also calculated for analytes using the measured and method detection limit values. The DF was obtained by taking the concentration of the analyte in the blended feed and dividing it by the concentration of the same analyte in the condensate. As expected, these ratios varied significantly based on the chemistry of the solutions and the entrainment that occurred during the evaporation process. For example the ratios for the $\mathrm{Hg}$ $(3.1 \mathrm{E}-02)$ and the $\mathrm{Si}(1.6 \mathrm{E}+01)$ were low whereas the ratios for $\mathrm{Fe}(1.6 \mathrm{E}+04)$ and $\mathrm{Mn}(3.6 \mathrm{E}+04)$ were high. A table containing the calculated DF factors can be found in Appendix B (Table B-4, next to last column). It should be noted that the majority of the DF factors were calculated based on sample detection limits and likely significantly understate the actual DF of the process.

As noted in Table 4, several of the analytes were not measured. In order to determine the activities of the remaining radionuclides in Table 4, the CF for the blended feed, the SB3 sludge slurry data ${ }^{14}$, and the ratios of the counting data obtained for the blended feed were used as well as the DF of the blended feed. Projecting the concentrations of these analytes was necessary in order to compare the condensate results to the $\mathrm{F} / \mathrm{H}$ ETP $\mathrm{WAC}^{11}$ and to complete a mass balance for the system. Several assumptions were made based on the chemistry of the components in a nitric acid solution. For example, it was assumed that the ratio of the Pu-238 activity to total alpha activity and the ratio of the Ni-59 concentration to the total $\mathrm{Ni}$ was the same for the condensate as the blended feed. Therefore, if one knew the activity for the total alpha of a sample the $\mathrm{Pu}-238$ activity could be calculated or, if the concentration of Ni were known for a sample the Ni-59 activity could be calculated. It was also assumed that the I-129 and H-3 were $100 \%$ volatile while boiled during the evaporation process and were retained in the condensate. The DF for Fe was used to calculate the concentration of the Se-79 in the condensate, because 
the Se-79 is thought to be either selenous or selenic acid which has a boiling point of $315^{\circ} \mathrm{C}$ and $260^{\circ} \mathrm{C}$, respectively. The C-14 was not measured for the blended feed, concentrate, or the condensate. A technical report has been recently issued concerning the form and fate of C-14 in the DWPF process. ${ }^{15}$ The $\mathrm{C}-14$ is present as a carbonate in the sludge and is neutralized by nitric and formic acids and evolved as $\mathrm{CO}_{2}$ during SRAT processing. Table 5 presents the results of the calculations for the radioactive analytes not reported in Table 4.

Table 5. Calculated Activities for Radioactive Analytes Not Measured in Table 4

\begin{tabular}{|c|c|c|c|c|}
\hline Category & Analyte & $\begin{array}{c}\text { Blended Feed } \\
\text { Average }\end{array}$ & $\begin{array}{c}\text { Concentrate } \\
\text { Average }\end{array}$ & $\begin{array}{c}\text { Condensate } \\
\text { Average }\end{array}$ \\
\hline $\begin{array}{c}\text { Radionuclides } \\
(\mathbf{d} / \mathbf{m} / \mathbf{m L})\end{array}$ & $\mathrm{H}-3$ & $*$ & $<6 \mathrm{E}+02^{\mathrm{b}}$ & $<6 \mathrm{E}+02^{\mathrm{c}}$ \\
\hline & $\mathrm{Ni}-59$ & $*$ & $1 \mathrm{E}+05^{\mathrm{d}}$ & $<6 \mathrm{E}+00^{\mathrm{d}}$ \\
\hline & $\mathrm{Ni}-63$ & $*$ & $1 \mathrm{E}+07^{\mathrm{e}}$ & $<6 \mathrm{E}+02^{\mathrm{e}}$ \\
\hline & $\mathrm{Se}-79$ & $*$ & $4.9 \mathrm{E}+04^{\mathrm{b}}$ & $1.1 \mathrm{E}-02^{\mathrm{f}}$ \\
\hline & $\mathrm{Sb}-125$ & $*$ & $1.4 \mathrm{E}+04^{\mathrm{b}}$ & $3.3 \mathrm{E}-02^{\mathrm{f}}$ \\
\hline & $\mathrm{I}-129$ & $2.4 \mathrm{E}+00^{\mathrm{a}}$ & $8.3 \mathrm{E}+01^{\mathrm{a}}$ & $1.4 \mathrm{E}+00^{\mathrm{c}}$ \\
\hline & $\mathrm{Cs}-135$ & $*$ & $1.3 \mathrm{E}+04^{\mathrm{a}}$ & $<4 \mathrm{E}+02^{\mathrm{g}}$ \\
\hline & $\mathrm{Pm}-147$ & $*$ & $3.4 \mathrm{E}+06^{\mathrm{h}}$ & $<9 \mathrm{E}+00^{\mathrm{h}}$ \\
\hline & $\mathrm{Pu}-238$ & $\mathrm{Pu}-241$ & $7.2 \mathrm{E}+06^{\mathrm{i}}$ & $<2 \mathrm{E}+01^{\mathrm{i}}$ \\
\hline
\end{tabular}

* Activities for these analytes have been reported in Table 4

${ }^{a}$ Used a Cs-135/Cs-137 (4.2E-06) calculated from SB3 concentrations and multiplied by the activity of Cs-137 in the blended feed to calculate the activity of Cs-135. Repeated the same protocol to determine the Cs-135 activities for the concentrate and the condensate samples.

${ }^{\mathrm{b}}$ Assumed DF of 1.0 and divided blended feed activity by DF

${ }^{\mathrm{c}}$ Assumed DF of 1.0 and divided blended feed activity by DF

${ }^{\mathrm{d}}$ Used the Ni-59/total Ni ratio of 1.31E+02 for the blended feed and multiplied by total Ni in the concentrate and condensate to obtain the Ni-59 activity for the concentrate and condensate.

${ }^{\mathrm{e}}$ Used the Ni-63/total Ni ratio of 1.44E+04 for the blended feed and multiplied by total Ni in the concentrate and condensate to obtain the Ni-63 activity for the concentrate and condensate.

${ }^{\mathrm{f}}$ Used DF of $1.6 \mathrm{E} 4$ and divided blended feed activity by the DF.

${ }^{g}$ Used the Pm-147/Sm-151 ratio of 1.06 and multiplied by Sm-151 activities for the concentrate and the condensate samples to obtain Pm-147 activity for the concentrate and condensate.

${ }^{\mathrm{h}}$ Used the Pu-238/total alpha ratio of 2.16E-01 and multiplied by total alpha activity for the concentrate and the condensate to obtain the $\mathrm{Pu}-238$ activity for the concentrate and the condensate.

${ }^{\mathrm{i}}$ Used the Pu-241/total alpha ratio of 4.63E-01 and multiplied by total alpha activity for the concentrate and the condensate to obtain the $\mathrm{Pu}-241$ activity for the concentrate and the condensate.

\subsubsection{Condensate Results Comparison to F/H ETP WAC Limits}

Based on the data reported in column 5 of Table 3, Table 4, and Table 5 for the condensate, it was then compared to the $\mathrm{F} / \mathrm{H}$ ETP WAC ${ }^{11}$. Table 6 compares the condensate analytes to the F/H ETP WAC. Table cells are highlighted if the WAC limits are exceeded or if the detection limit was higher than the WAC limit. 
Table 6. Comparison the Condensate Analytes to the F/H ETP WAC

\begin{tabular}{|c|c|c|c|c|}
\hline Category & Analyte & $\begin{array}{l}\text { Condensate } \\
\text { Average }\end{array}$ & $\begin{array}{c}\text { F/H ETP } \\
\text { WAC Limits }\end{array}$ & $\begin{array}{c}\text { Does the } \\
\text { Condensate Meet } \\
\text { the WAC Limit? }\end{array}$ \\
\hline $\begin{array}{c}\text { Wt.\% Solids and } \\
\text { Density }\end{array}$ & $\begin{array}{c}\text { Wt. \% Total Solids of } \\
\text { Slurry }\end{array}$ & $\begin{array}{l}\text { No Solids } \\
\text { Detected }\end{array}$ & $1.00 \mathrm{E} 2$ & yes \\
\hline \multirow[t]{3}{*}{ Wet Chem } & $\begin{array}{c}\text { Total Organic Carbon, } \\
\text { mg/L }\end{array}$ & $6.86 \mathrm{E}+01$ & 3.85E02 & yes \\
\hline & $\begin{array}{l}\text { Total Inorganic Carbon } \\
\text { (i.e. Carbonate), mg/L }\end{array}$ & $<1 \mathrm{E}+01$ & 1.12E03 & yes \\
\hline & Particle Size & $\begin{array}{c}\text { No visible } \\
\text { solids }\end{array}$ & $\begin{array}{l}40 \text { Mesh (350 } \\
\text { Micron) }\end{array}$ & yes \\
\hline \multirow[t]{2}{*}{ Titration } & $\mathrm{pH}$ & 3.2 & 1 to 12.5 & yes \\
\hline & Chloride & $<3 \mathrm{E}+00$ & $3.00 \mathrm{E}+01$ & yes \\
\hline \multirow[t]{7}{*}{$\begin{array}{l}\text { IC Cation and Anions } \\
\text { (mg/L of supernate) }\end{array}$} & Fluoride & $<3 \mathrm{E}+00$ & $1.26 \mathrm{E}+01$ & yes \\
\hline & Nitrate & $4.85 \mathrm{E}+01$ & $1.18 \mathrm{E}+03$ & yes \\
\hline & Nitrite & $<1 \mathrm{E}+01$ & $1.99 \mathrm{E}+03$ & yes \\
\hline & Oxalate & $<1 \mathrm{E}+01$ & $2.54 \mathrm{E}+02$ & yes \\
\hline & Phosphate & $<1 \mathrm{E}+01$ & $1.84 \mathrm{E}+01$ & yes \\
\hline & Sulfate & $5.00 \mathrm{E}+00$ & $1.33 \mathrm{E}+02$ & yes \\
\hline & Ammonium & $<1 \mathrm{E}+01$ & $2.80 \mathrm{E}+01$ & yes \\
\hline \multirow[t]{24}{*}{$\begin{array}{l}\text { ICP-ES and AA } \\
\text { Results (mg/L) }\end{array}$} & $\mathrm{Ag}$ & $<1 \mathrm{E}-02$ & $7.82 \mathrm{E}+01$ & yes \\
\hline & $\mathrm{Al}$ & 1.61E-01 & $1.08 \mathrm{E}+03$ & yes \\
\hline & As & $<3 \mathrm{E}-02$ & $5.77 \mathrm{E}+00$ & yes \\
\hline & B & $1.40 \mathrm{E}-01$ & $6.92 \mathrm{E}+00$ & yes \\
\hline & $\mathrm{Ba}$ & $<3 \mathrm{E}-02$ & $5.77 \mathrm{E}+00$ & yes \\
\hline & $\mathrm{Be}$ & $<2 \mathrm{E}-03$ & $5.00 \mathrm{E}+00$ & yes \\
\hline & $\mathrm{Ca}$ & $8.25 \mathrm{E}-02$ & $2.12 \mathrm{E}+01$ & yes \\
\hline & $\mathrm{Cd}$ & $<5 \mathrm{E}-03$ & $2.58 \mathrm{E}+00$ & yes \\
\hline & $\mathrm{Cr}$ & $<3 \mathrm{E}-02$ & $8.40 \mathrm{E}+00$ & yes \\
\hline & $\mathrm{Cu}$ & $<1 \mathrm{E}-02$ & $8.48 \mathrm{E}+01$ & yes \\
\hline & $\mathrm{Fe}$ & 2.95E-02 & $4.62 \mathrm{E}+01$ & yes \\
\hline & $\mathrm{Hg}$ & $3.30 \mathrm{E}+00$ & $4.06 \mathrm{E}+01$ & yes \\
\hline & $\mathrm{K}$ & $<2 \mathrm{E}-01$ & $2.82 \mathrm{E}+02$ & yes \\
\hline & $\mathrm{Li}$ & $<5 \mathrm{E}-02$ & $6.92 \mathrm{E}+00$ & yes \\
\hline & $\mathrm{Mn}$ & $<2 \mathrm{E}-03$ & $6.92 \mathrm{E}+00$ & yes \\
\hline & Mo & $<2 \mathrm{E}-01$ & $6.92 \mathrm{E}+00$ & yes \\
\hline & $\mathrm{Na}$ & $<4 \mathrm{E}-01$ & $1.24 \mathrm{E}+03$ & yes \\
\hline & $\mathrm{Ni}$ & $<4 \mathrm{E}-02$ & $6.92 \mathrm{E}+00$ & yes \\
\hline & $\mathrm{Pb}$ & $<8 \mathrm{E}-01$ & $3.71 \mathrm{E}+01$ & yes \\
\hline & $\mathrm{Sb}$ & $<1 \mathrm{E}-01$ & $2.17 \mathrm{E}+02$ & yes \\
\hline & Se & $<6 \mathrm{E}-02$ & $3.46 \mathrm{E}+00$ & yes \\
\hline & $\mathrm{Si}$ & $1.10 \mathrm{E}+01$ & $9.92 \mathrm{E}+01$ & yes \\
\hline & $\mathrm{Sr}$ & $<1 \mathrm{E}-02$ & $6.92 \mathrm{E}+00$ & yes \\
\hline & $\mathrm{Zn}$ & $7.60 \mathrm{E}-02$ & $7.50 \mathrm{E}+00$ & yes \\
\hline & Co-59 & $<2 \mathrm{E}-05$ & $6.92 \mathrm{E}+00$ & yes \\
\hline \multirow[t]{3}{*}{$\begin{array}{c}\text { Counting and ICP-MS } \\
(\mathrm{d} / \mathrm{m} / \mathrm{mL})\end{array}$} & Alpha & $<4 \mathrm{E}+01$ & $1.00 \mathrm{E}+02$ & yes \\
\hline & Beta & $1.55 \mathrm{E}+03$ & $2.50 \mathrm{E}+03$ & yes \\
\hline & $\mathrm{H}-3$ & $<6 \mathrm{E}+02^{*}$ & $1.20 \mathrm{E}+05$ & yes \\
\hline
\end{tabular}


WSRC-TR-2005-00309

Revision 0

\begin{tabular}{|c|c|c|c|c|}
\hline Category & Analyte & $\begin{array}{l}\text { Condensate } \\
\text { Average }\end{array}$ & $\begin{array}{c}\text { F/H ETP } \\
\text { WAC Limits }\end{array}$ & $\begin{array}{l}\text { Does the } \\
\text { Condensate Meet } \\
\text { the WAC Limit? }\end{array}$ \\
\hline & C-14 & N.M. & $1.91 \mathrm{E}+03$ & yes \\
\hline \multirow[t]{37}{*}{\begin{tabular}{|c|} 
Counting and ICP-MS \\
$(\mathrm{d} / \mathrm{m} / \mathrm{mL})$
\end{tabular}} & Al-26 & $<3 \mathrm{E}-01$ & $4.87 \mathrm{E}+01$ & yes \\
\hline & $\mathrm{Ni}-59$ & $<6 \mathrm{E}+00^{*}$ & $1.91 \mathrm{E}+03$ & yes \\
\hline & $\mathrm{Ni}-63$ & $<6 \mathrm{E}+02^{*}$ & $1.91 \mathrm{E}+03$ & yes \\
\hline & Co-60 & 2.97E-01 & $1.30 \mathrm{E}+01$ & yes \\
\hline & Se-79 & $1.1 \mathrm{E}-02^{*}$ & $1.76 \mathrm{E}+03$ & yes \\
\hline & Sr-90 & $<2 \mathrm{E}+03$ & $1.76 \mathrm{E}+02$ & indeterminate \\
\hline & Nb-94 & $<3 \mathrm{E}-01$ & $2.59 \mathrm{E}+02$ & yes \\
\hline & Тc-99 & $<7 \mathrm{E}+00$ & $2.50 \mathrm{E}+03$ & yes \\
\hline & Ru-106 & $<2 \mathrm{E}+00$ & $7.92 \mathrm{E}+02$ & yes \\
\hline & Sn-126 & $<8 \mathrm{E}-01$ & $9.38 \mathrm{E}+01$ & yes \\
\hline & Sb-125 & $<4 \mathrm{E}+02$ & $2.50 \mathrm{E}+02$ & yes \\
\hline & I-129 & $7.35 \mathrm{E}+00^{*}$ & $1.00 \mathrm{E}+00$ & no \\
\hline & Cs-134 & $<3 \mathrm{E}-01$ & $2.50 \mathrm{E}+03$ & yes \\
\hline & Cs-135 & $1.7 \mathrm{E}-04^{*}$ & $2.50 \mathrm{E}+03$ & yes \\
\hline & Cs-137 & $3.90 \mathrm{E}+01$ & $1.20 \mathrm{E}+03$ & yes \\
\hline & Pm-147 & $<4 \mathrm{E}+02^{*}$ & $2.50 \mathrm{E}+03$ & yes \\
\hline & Sm-151 & $<3 \mathrm{E}+02$ & $3.81 \mathrm{E}+02$ & yes \\
\hline & Eu-154 & $6.48 \mathrm{E}-01$ & $2.50 \mathrm{E}+01$ & yes \\
\hline & Eu-155 & $<1 \mathrm{E} 00$ & $1.91 \mathrm{E}+02$ & yes \\
\hline & Ra-226 & $<6 \mathrm{E}+00$ & $8.80 \mathrm{E}+00$ & yes \\
\hline & Th-230 & $<2 \mathrm{E}-01$ & $5.28 \mathrm{E}+01$ & yes \\
\hline & Th-232 & $<5 \mathrm{E}-06$ & $8.80 \mathrm{E}+00$ & yes \\
\hline & U-233 & $<3 \mathrm{E}-01$ & $6.60 \mathrm{E}+01$ & yes \\
\hline & U-234 & $<1 \mathrm{E}-01$ & $6.60 \mathrm{E}+01$ & yes \\
\hline & U-235 & $<5 \mathrm{E}-05$ & 6.09E-01 & yes \\
\hline & U-236 & $<7 \mathrm{E}-04$ & $6.60 \mathrm{E}+01$ & yes \\
\hline & U-238 & $1.72 \mathrm{E}-03$ & $7.92 \mathrm{E}+01$ & yes \\
\hline & Np-237 & $<8 \mathrm{E}-03$ & $3.96 \mathrm{E}+00$ & yes \\
\hline & $\mathrm{Pu}-238$ & $<9 \mathrm{E}+00^{*}$ & $5.28 \mathrm{E}+00$ & indeterminate \\
\hline & Pu-239 & $<7 \mathrm{E}-01$ & $3.96 \mathrm{E}+00$ & yes \\
\hline & Pu-240 & $<5 \mathrm{E}+00$ & $3.96 \mathrm{E}+00$ & indeterminate \\
\hline & $\mathrm{Pu}-241$ & $<2 \mathrm{E}+01^{*}$ & $2.64 \mathrm{E}+02$ & yes \\
\hline & $\mathrm{Pu}-242$ & $<1 \mathrm{E}-01$ & $3.96 \mathrm{E}+00$ & yes \\
\hline & Am-241 & $<2 \mathrm{E}+00$ & $3.96 \mathrm{E}+00$ & yes \\
\hline & Am-243 & $<4 \mathrm{E}+00$ & $3.96 \mathrm{E}+00$ & indeterminate \\
\hline & Cm-244 & $<9 \mathrm{E}+02$ & $7.92 \mathrm{E}+00$ & indeterminate \\
\hline & $\begin{array}{l}\text { Radiation Control } \\
\text { Guide (RCG) }\end{array}$ & $1.06 \mathrm{E}-03$ & 7.69E-03 & yes \\
\hline
\end{tabular}

* Calculated values from Table 5

As can be seen in Table 6 the majority of the analytes met the F/H ETP WAC. However, the activities reported for Sr-90, I-129, Pu-238, Pu-240, Am-243, and Cm-244 exceeded the ETP WAC limits. The reported activities for all of these components in the condensate are based on the method detection limits (except for I-129) or are calculated from results that were based on the method detection limits; therefore, the sample may not have actually exceeded the limits for these species. To confirm this, better method detection limits would have to be obtained for the condensate samples. 


\subsection{Blended Feed Comparison to Previous Samples}

The blended feed consists of SMECT and OGCT condensates recently sampled from DWPF. Previous samples from these tanks have been received and analyzed ${ }^{8}$ as shown in Table 7. Two previous samples of SMECT condensate are shown, indicated by (a) and (D) designations. The sample results indicate a significant amount of variation in the samples. One source of variation for the SMECT condensate is the difference in composition expected for condensate from the SRAT cycle versus condensate from the SME cycle. Mercury stripping during the SRAT cycle will generate higher concentrations of mercury in SRAT condensate while antifoam addition variations during the SRAT and SME cycles would lead to variation in the silicon content of the condensate.

Table 7. Comparison of Blended Feed Composition to Previous Sample Results

\begin{tabular}{|c|c|c|c|c|c|}
\hline Species / Property & Units & Blended Feed & $\begin{array}{c}\text { Previous } \\
\text { SMECT (a) } \\
\text { Sample }\end{array}$ & $\begin{array}{c}\text { Previous } \\
\text { SMECT (D) } \\
\text { Sample }\end{array}$ & $\begin{array}{c}\text { Previous OGCT } \\
\text { Sample }\end{array}$ \\
\hline Total Solids & $\mathrm{Wt} \%$ & 0.214 & $<0.001$ & 0.008 & 0.44 \\
\hline $\mathrm{pH}$ & & 2.0 & 1.3 & 1.5 & 2.3 \\
\hline $\mathrm{Hg}$ & $\mathrm{mg} / \mathrm{L}$ & $<0.1$ & 170 & 110 & 0.036 \\
\hline $\mathrm{Fe}$ & $\mathrm{mg} / \mathrm{L}$ & 470 & 0.61 & 1.5 & 226 \\
\hline $\mathrm{Si}$ & $\mathrm{mg} / \mathrm{L}$ & 181 & 340 & 120 & 3.64 \\
\hline $\mathrm{U}$ & $\mathrm{mg} / \mathrm{L}$ & 33.5 & 0.48 & 2.3 & 1.52 \\
\hline Nitrate & $\mathrm{mg} / \mathrm{L}$ & 1820 & 7600 & 2600 & 1590 \\
\hline Formate & $\mathrm{mg} / \mathrm{L}$ & 195 & 140 & 430 & $<0.14$ \\
\hline
\end{tabular}

The variation expected in recycle compositions must be considered when drawing conclusions from the test. For example, the mercury in the blended feed was below the limits for the $\mathrm{F} / \mathrm{H}$ ETP WAC, therefore the condensate was below the limits. However, the DF for mercury of the evaporator was very low based on the concentrate and condensate results. Therefore, high mercury carry over to the condensate would be expected, and the F/H ETP WAC limits would likely be exceeded if the feed concentration is initially higher than the WAC limit. If the feed had been at the levels noted in the previous SMECT samples, then the WAC limit would likely have been exceeded.

\subsection{Comparisons to Simulant Evaporator Testing and OLI Model Results}

Comparisons between the radioactive test and similar tests conducted with simulants were made for the physical properties of the feed, concentrate, and condensate as well as the DF factors and processing characteristics. Comparisons were also conducted between the radioactive test and the OLI results previously obtained for the physical properties of the feed, concentrate, and condensate as well as the DF factors.

\subsubsection{Simulant Evaporation Test Comparison}

Simulant testing was conducted by SRNL prior to the radioactive Shielded Cells run. This testing was documented in a separate report ${ }^{2}$. The apparatus and operating procedure for the simulant testing was adapted and utilized during the Shielded Cells runs, therefore the simulant and radioactive runs were conducted in a similar manner. Two significant changes were made to the process strategy during the radioactive runs. First, the foam level in the evaporator was controlled using addition of an antifoam agent (Dow Corning 2210) during the radioactive process versus control of the boil-up rate during simulant testing. Second, the simulant testing 
included a period of steady-state boiling at the end of the run while the radioactive tests were stopped when the concentration endpoint was reached to avoid problems trying to remove very small amounts of concentrate from the vessel during the run.

Overall agreement between the results of the simulant testing and the radioactive tests was good, as discussed below. The processing characteristics and composition results were similar and indicate that the simulant was conservative in behavior.

\subsubsection{Process characteristics}

A major objective of the test programs was to determine the overall process characteristics (foaming, scaling, etc.) of the DWPF recycle stream. Both the simulant and radioactive testing indicated that processing the recycle streams through an evaporator is feasible, but two processing issues were identified. Foaming was noted during both the simulant and radioactive runs as well as splattering on the vessel walls. It should be noted that the higher amounts of solids, especially mercury, in the simulant may have affected the comparison.

\subsection{Foaming}

Foaming was noted during simulant testing and radioactive testing. The boil-up rate was adjusted during simulant testing to reduce the foam to acceptable levels because an acceptable antifoam agent had not been identified. During simulant testing, a large amount of foam was noted at the onset of boiling and reduced amounts of foam were noted during the remainder of the run. The large spike in foaminess was not noted during the radioactive tests at the onset of boiling, but foam was noted throughout the radioactive test. Overall appearance of the foaming was similar to the simulant testing after the initial foaming in the simulant testing had subsided, as shown in Figure 7.

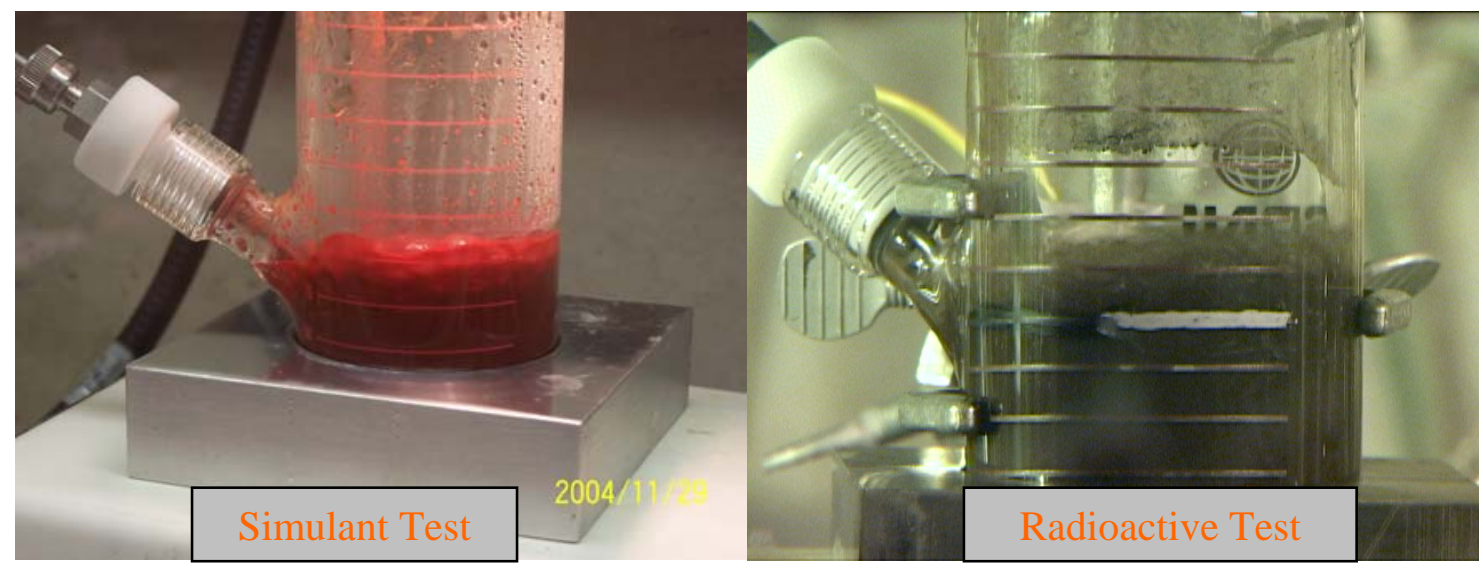

Figure 7. Foaming During Evaporation Tests.

One major difference between the simulants and the actual recycle that could explain the difference in foaming behavior is the use of fresh antifoam to simulate the antifoam degradation products noted in the SMECT condensate. A comparison was made between the simulated SMECT condensate and the SMECT condensate from simulant SRAT/SME runs by shaking bottles of each and observed the amount of foam formed and the persistence of the foam lamella. Simulated SMECT condensate generated more foam and the foam was more persistent than the 
SMECT condensate from SRAT runs. The foaminess of the simulated SMECT condensate was conservative, therefore it should be adequate to perform antifoam testing.

\subsection{Scaling}

No scaling or fouling of the evaporator or other surfaces was noted in either test below the liquid level. However, both the simulant and radioactive runs exhibited splatter on the walls above the level reached by the foam, as shown in Figure 8. The splatter was significantly less for the radioactive test than during simulant runs. The longer duration of the simulant runs due to reducing the boil-up rate to control foaming may have led to more buildup or addition of antifoam during the radioactive run could have reduced the amount of splattering. Antifoam agents modify the surface properties of particles and can aid in minimizing wall deposits ${ }^{17}$.

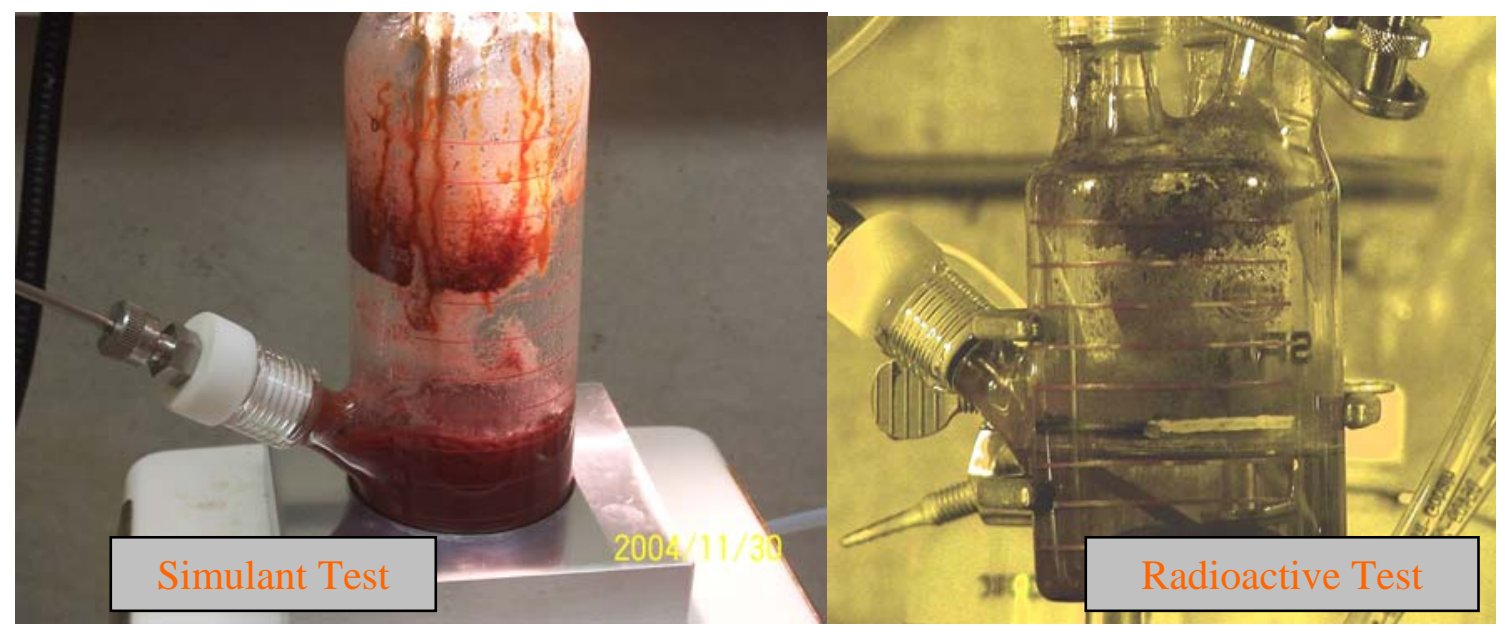

Figure 8. Splatter During Evaporation Tests.

\subsection{Chemical Composition and Physical Properties.}

The chemical composition of the feed, condensate, and concentrate along with selected physical properties is shown in Table 8. Also shown is the calculated concentration factor based on the ratio of a species concentration in the concentrate to the concentration in the feed. The three simulant tests were averaged to determine the values for the simulant testing ${ }^{2}$.

Agreement was noted between the simulant and radioactive tests in that entrainment was very low based on condensate results during the evaporation testing and the concentration factor for most species matched the expected concentration based on volumes during the test. Based on the concentrate samples, selected species (silicon and formate) were evaporated from the vessel into the offgas during both runs. The solids content data indicates that appreciable quantities of solids were dissolved during both runs.

An individual comparison of DF's was not performed between the tests because most DF's were based on sample detection limits, not process performance. A comparison of the concentration factors and stream compositions indicates good agreement for most species. Four species (B, K, $\mathrm{Mo}$, and $\mathrm{Sb}$ ) had low concentration factors during simulant testing but the radioactive testing indicated high concentration factors. The material balance closure on all four species was very 
poor during simulant testing, therefore the radioactive results are likely more representative of the behavior of these species (see Appendix B, Table B-4 for mass balance). Aluminum and zinc had concentration factors during simulant testing that greatly exceeded the average concentration factor and are likely not representative for the simulant runs.

The mercury concentration factor for the radioactive test was much higher than the simulant. The condensate and concentrate results indicated a feed concentration of approximately 3.3 and that $97 \%$ of the mercury went to the overheads. The average results for the simulant studies indicated far better closure of the material balance for mercury, although a lot of scatter was present in the actual data. Based on the material balance closure, the simulant results were likely more representative.

Table 8. Comparison of Chemical Composition of Simulant Runs to Radioactive Test

\begin{tabular}{|c|c|c|c|c|c|c|c|c|c|}
\hline \multirow[b]{2}{*}{ Species } & \multirow[b]{2}{*}{ Units } & \multicolumn{2}{|c|}{ Blended Feed } & \multicolumn{2}{|c|}{ Concentrate } & \multicolumn{2}{|c|}{ Condensate } & \multicolumn{2}{|c|}{$\begin{array}{l}\text { Concentration } \\
\text { Factor }\end{array}$} \\
\hline & & $\begin{array}{l}\text { Simulant } \\
\text { Average }\end{array}$ & $\begin{array}{l}\text { Rad } \\
\text { Test }\end{array}$ & $\begin{array}{c}\text { Simulant } \\
\text { Average } \\
\end{array}$ & $\begin{array}{l}\text { Rad } \\
\text { Test }\end{array}$ & $\begin{array}{r}\text { Simulant } \\
\text { Average } \\
\end{array}$ & $\begin{array}{l}\text { Rad } \\
\text { Test }\end{array}$ & $\begin{array}{c}\text { Simulant } \\
\text { Average } \\
\end{array}$ & $\begin{array}{l}\text { Rad } \\
\text { Test }\end{array}$ \\
\hline $\mathrm{Ag}$ & $\mathrm{mg} / \mathrm{L}$ & LTD & 0.323 & 0.771 & 9.62 & LTD & LTD & - & 29.78 \\
\hline $\mathrm{Al}$ & $\mathrm{mg} / \mathrm{L}$ & 9.17 & 61 & 461 & 1340 & 0.150 & 0.161 & 50.2 & 21.97 \\
\hline $\mathrm{B}$ & $\mathrm{mg} / \mathrm{L}$ & 4.83 & 2.57 & 8.18 & 78.5 & 0.791 & 0.14 & 1.7 & 30.54 \\
\hline $\mathrm{Ba}$ & $\mathrm{mg} / \mathrm{L}$ & 0.479 & 0.781 & 9.07 & 17.9 & LTD & LTD & 18.9 & 22.92 \\
\hline $\mathrm{Ca}$ & $\mathrm{mg} / \mathrm{L}$ & 16.2 & 9.09 & 494 & 275 & LTD & 0.083 & 30.6 & 30.25 \\
\hline $\mathrm{Ce}$ & $\mathrm{mg} / \mathrm{L}$ & LTD & LTD & 0.139 & 28.2 & LTD & LTD & - & - \\
\hline $\mathrm{Cr}$ & $\mathrm{mg} / \mathrm{L}$ & LTD & 1.55 & 2.63 & 31 & LTD & LTD & - & 20.00 \\
\hline $\mathrm{Cu}$ & $\mathrm{mg} / \mathrm{L}$ & 0.361 & 0.914 & 12.5 & 27.6 & LTD & LTD & 34.8 & 30.20 \\
\hline $\mathrm{Fe}$ & $\mathrm{mg} / \mathrm{L}$ & 927 & 470 & 27600 & 10300 & LTD & LTD & 29.8 & 21.91 \\
\hline $\mathrm{Gd}$ & $\mathrm{mg} / \mathrm{L}$ & LTD & 0.486 & 8.66 & 12.7 & LTD & LTD & - & 26.13 \\
\hline $\mathrm{K}$ & $\mathrm{mg} / \mathrm{L}$ & 3.57 & 0.412 & 22.8 & 13 & 0.239 & 0.15 & 6.4 & 31.55 \\
\hline $\mathrm{Li}$ & $\mathrm{mg} / \mathrm{L}$ & LTD & 3.46 & 5.46 & 79.7 & LTD & LTD & - & 23.03 \\
\hline $\mathrm{Mg}$ & $\mathrm{mg} / \mathrm{L}$ & 31.5 & 28.9 & 874 & 682 & LTD & LTD & 27.8 & 23.60 \\
\hline $\mathrm{Mn}$ & $\mathrm{mg} / \mathrm{L}$ & 63.2 & 72.3 & 1977 & 1750 & LTD & LTD & 31.3 & 24.20 \\
\hline Mo & $\mathrm{mg} / \mathrm{L}$ & 0.867 & 1.3 & 0.812 & 25.4 & 0.062 & LTD & 0.9 & 19.54 \\
\hline $\mathrm{Na}$ & $\mathrm{mg} / \mathrm{L}$ & 138 & 77.1 & 3890 & 2280 & 0.507 & LTD & 28.3 & 29.57 \\
\hline $\mathrm{Ni}$ & $\mathrm{mg} / \mathrm{L}$ & 15.6 & 27.8 & 436 & 611 & LTD & LTD & 28.0 & 21.98 \\
\hline $\mathrm{P}$ & $\mathrm{mg} / \mathrm{L}$ & LTD & 5.87 & 5.52 & 136 & LTD & LTD & - & 23.17 \\
\hline $\mathrm{Pb}$ & $\mathrm{mg} / \mathrm{L}$ & LTD & 0.871 & 7.04 & 23.5 & LTD & LTD & - & 26.98 \\
\hline $\mathrm{S}$ & $\mathrm{mg} / \mathrm{L}$ & 10.0 & 8.42 & 319 & 246 & LTD & 0.28 & 31.7 & 29.22 \\
\hline $\mathrm{Sb}$ & $\mathrm{mg} / \mathrm{L}$ & 1.75 & 1.59 & 5.73 & 34.1 & LTD & LTD & 3.3 & 21.45 \\
\hline $\mathrm{Si}$ & $\mathrm{mg} / \mathrm{L}$ & 62.1 & 181 & 301 & 1760 & 67 & 11 & 4.8 & 9.72 \\
\hline Sn & $\mathrm{mg} / \mathrm{L}$ & LTD & LTD & 0.763 & 49.3 & LTD & LTD & - & - \\
\hline
\end{tabular}


WSRC-TR-2005-00309

Revision 0

\begin{tabular}{|c|c|c|c|c|c|c|c|c|c|}
\hline \multirow[b]{2}{*}{ Species } & \multirow[b]{2}{*}{ Units } & \multicolumn{2}{|c|}{ Blended Feed } & \multicolumn{2}{|c|}{ Concentrate } & \multicolumn{2}{|c|}{ Condensate } & \multicolumn{2}{|c|}{$\begin{array}{c}\text { Concentration } \\
\text { Factor } \\
\end{array}$} \\
\hline & & $\begin{array}{l}\text { Simulant } \\
\text { Average }\end{array}$ & $\begin{array}{l}\text { Rad } \\
\text { Test }\end{array}$ & $\begin{array}{l}\text { Simulant } \\
\text { Average }\end{array}$ & $\begin{array}{l}\text { Rad } \\
\text { Test }\end{array}$ & $\begin{array}{l}\text { Simulant } \\
\text { Average }\end{array}$ & $\begin{array}{l}\text { Rad } \\
\text { Test }\end{array}$ & $\begin{array}{l}\text { Simulant } \\
\text { Average }\end{array}$ & $\begin{array}{l}\text { Rad } \\
\text { Test }\end{array}$ \\
\hline $\mathrm{Sr}$ & $\mathrm{mg} / \mathrm{L}$ & LTD & LTD & 1.23 & 59.8 & LTD & LTD & - & - \\
\hline $\mathrm{Ti}$ & $\mathrm{mg} / \mathrm{L}$ & LTD & 0.417 & 1.57 & 9.77 & LTD & LTD & - & 23.43 \\
\hline $\mathrm{Zn}$ & $\mathrm{mg} / \mathrm{L}$ & 0.134 & 0.969 & 26.8 & 24.4 & LTD & LTD & 200.2 & 25.18 \\
\hline $\mathrm{Zr}$ & $\mathrm{mg} / \mathrm{L}$ & LTD & 1.79 & 2.25 & 32.6 & LTD & LTD & - & 18.21 \\
\hline NO3 & $\mathrm{mg} / \mathrm{L}$ & 3800 & 1820 & 109,867 & 57,100 & 378 & 48.5 & 28.9 & 31.37 \\
\hline HCO2 & $\mathrm{mg} / \mathrm{L}$ & 381 & 195 & 393 & 349 & & 166 & 1.0 & 1.79 \\
\hline $\mathrm{Hg}$ & $\mathrm{mg} / \mathrm{L}$ & 170 & 0.102 & 2680 & 2.99 & 80.5 & 3.3 & 15.7 & 29.31 \\
\hline $\begin{array}{c}\text { Physical } \\
\text { Properties }\end{array}$ & & & & & & & & & \\
\hline $\begin{array}{c}\text { Slurry } \\
\text { Density }\end{array}$ & $\mathrm{g} / \mathrm{ml}$ & 1.00 & 1.01 & 1.10 & 1.08 & LTD & LTD & - & - \\
\hline $\begin{array}{l}\text { Supernate } \\
\text { Density }\end{array}$ & $\mathrm{g} / \mathrm{ml}$ & 1.00 & 1.01 & 1.07 & 1.05 & 0.998 & 1.01 & - & - \\
\hline Total Solids & $\mathrm{wt} \%$ & 0.250 & 0.214 & 8.35 & 5.01 & 0.0 & 0 & 33.4 & 23.41 \\
\hline $\begin{array}{c}\text { Soluble } \\
\text { Solids } \\
\end{array}$ & $\mathrm{wt} \%$ & 0.100 & 0.01 & 4.45 & 3.93 & LTD & LTD & 44.5 & - \\
\hline $\begin{array}{c}\text { Insoluble } \\
\text { Solids } \\
\end{array}$ & wt $\%$ & 0.150 & 0.214 & 3.89 & 1.22 & LTD & LTD & 26.0 & 5.70 \\
\hline $\mathrm{pH}$ & & 1.3 & 2.0 & 2.6 & 1.0 & 2.3 & 3.2 & - & - \\
\hline Titration & Molar & 0.048 & 0.029 & 1.21 & 0.688 & LTD & LTD & 25.3 & 24.14 \\
\hline
\end{tabular}

LTD: Less than detectable , - : Not calculated for this run

\subsubsection{OLI Model Comparison}

OLI modeling was completed using a matrix of feed compositions and recycle stream blending ratios. The manner in which entrained solids were incorporated into the OLI model resulted in a maximum DF of 30 for non-volatile species. When compared to the DF for non-volatile species during the radioactive test, the model results were overly conservative and would make further comparisons of the model to the radioactive tests non-representative.

The OLI model will be re-run with a more representative value for the entrainment and the results will be compared to the results of this test in a separate report. 


\subsection{CONCLUSIONS}

- The evaporation of DWPF recycle to achieve a 30X concentration factor was successfully demonstrated. The feed blend of OGCT and SMECT material was concentrated from $3000 \mathrm{~mL}$ to approximately $90 \mathrm{~mL}$ during testing, a concentration of approximately 33X.

- Foaming was observed during the run. Dow Corning 2210 antifoam was added seven times throughout the run at 100 parts per million (ppm) per addition. The addition of this antifoam was very effective in reducing the foam level, but the impact diminished over time and additional antifoam was required every 2 to 3 hours during the run.

- No scale or solids formed on the evaporator vessel, but splatter was observed in the headspace of the evaporator vessel. No scaling formed on the stainless steel thermocouple.

- The majority of the analytes meet the F/H ETP WAC. However, the detection limits for selected species (Sr-90, Pu-238, Pu-240, Am-243, and Cm-244) exceeded the ETP WAC limits.

- I-129 was calculated to have exceeded the ETP WAC limits based on an assumed DF of 1 during evaporation.

- The DF for most species was limited by the detection limits of the sample analysis. Based on iron, manganese, total alpha, total beta, and other species, very low entrainment was noted and evaporator DF was $>10,000$ for non-volatile species.

- Very low DF's were obtained for selected species, especially mercury and formate. These species are present as volatile compounds and will exceed ETP WAC limits if sufficient concentrations are in the evaporator feed.

- The evaporator DF's for the radioactive test were in good agreement with simulant test results. Differences noted in the DF of selected species, such as Hg, were more likely attributed to analytical issues than differences in the performance of the two evaporators.

- The simulant appeared to be conservative in terms of foaming and scaling characteristics of the evaporator. The initial spike in foaming that occurred during all simulant runs did not occur during the Shielded Cells run and overall foaminess after the start of the test was controlled by antifoam additions. The splatter that was deposited during the radioactive test was less than the simulant runs and was more easily removed.

- The OLI model results were overly conservative due to the manner that entrainment of solids was incorporated into the model. 


\subsection{RECOMMENDATIONS/PATH FORWARD}

- A camera and/or foam detection instrument should be included in the evaporator design to allow monitoring of the foaming behavior during operation.

- The potential for foam formation and high solids content should be considered during the design of the evaporator vessel.

- Continued evaluation of Dow Corning 2210 antifoam with simulants is warranted. The antifoam has been tested with simulated and actual recycle blends that represent normal operation. Additional tests that evaluate the performance of the antifoam with different recycle blends should be conducted.

- The OLI model results should be updated to reflect more representative values for entrainment of solids.

- Determination of the iodine DF for the recycle evaporator could be conducted with simulants, but the DF is expected to be very low. The DF required to meet the F/H ETP WAC limit is 7.35 for the feed tested during the Shielded Cells test and a margin above that is needed to account for variability in the feed concentration. It is unlikely that the experimentally determined DF would allow I-129 to meet the WAC limits. 


\subsection{REFERENCES}

1 Lambert, D.P., Barnes, C.D., and Phillips, S.G. DWPF Recycle Evaporator - Feasibility Study. WSRC-RP-2001-01101, Savannah River Site, Aiken, SC 29808 (2002).

2 Stone, M. E. DWPF Recycle Evaporator Simulant Tests. WSRC-TR-2005-00142, Savannah River Site, Aiken, SC 29808 (2005)

3 Daniel, W. E. and Taylor, G. A. Model Evaluation of DWPF Recycle Condensate Tank Evaporation Using OLI. WSRC-RP-2005-01426, Savannah River Site. Aiken, SC 29808 (2005)

4 Staub, A.V. Process Development for DWPF Recycle Acid Evaporator. Technical Task Request HLW/DWPF-TTR-2004-0020 Rev. 1., Savannah River Site, Aiken, SC 29808 (2004)

5 Stone, M. E. and Herman, D. T. Task Technical Quality Assurance Plan: Boildown Testing of Actual DWPF Recycle Material. WSRC-RP-2005-01467, Savannah River Site. Aiken, SC 29808 (2005)

6 Fellinger, T.L. and Herman, D.T. Analytical Study Plan for DWPF Recycle Evaporation SRNL-ITS-2005-00105, Savannah River Site, Aiken, SC 29808 (2005)

7 Laboratory Notebook DWPF Recycle Evaporation Boil Down Test 2. WSRC-NB-20050026, Savannah River Site, Aiken, SC 29808 (2005)

8 Fellinger, T.L. and Bibler, N.E. Results for the DWPF Slurry Mix Evaporator Condensate Tank, Off Gas Condensate Tank, and Recycle Collection Tank Samples. WSRC-TR-2004-00577, Savannah River Site, Aiken, SC 29808 (2004)

9 Pareizs, J.M., Koopman, D.C., Click, D.R. and Cozzi, A.D. Sludge Batch 3 Qualification in the SRTC Shielded Cells. WSRC-TR-2004-00050, Savannah River Site, Aiken, SC 29808 (2004)

10 Fellinger, T.L. and Hay, M.S. Characterization and Dissolution Test Results for the January 2005 DWPF Off Gas Condensate Tank Samples, WSRC-TR-2005-00141, Savannah River Site, Aiken, S.C. 29808 (2005).

11 Wiggins, A.W. F/H Effluent Treatment Project Waste Acceptance Criteria. X-SD-H00009, Rev.0, Savannah River Site, Aiken, SC 29808 (2004)

12 J.C. Marek, J. C. Correction Factor for Soluble and Insoluble Solids. SRTC-PTD-92-0040, Savannah River Site Aiken SC 29808 (1992)

13 Bibler N. E. and Edwards, T. B. Composition of Condensate Samples from the Sludge Receipt and Adjustment Tank and the Slurry Mix Evaporator in the DWPF. WSRC-RP2004-00575, Savannah River Site, Aiken, SC 29808 (2004)

14 Bannochie C. J. and Bibler, N. E. Determination of Reportable Radionuclides for DWPF Sludge Batch 3 (Macrobatch 4), WSRC-TR-2005-00157, Savannah River Site, Aiken, SC 29808 (2005)

15 Bibler N. E., Measuring and Predicting Fission Product Noble Metals in Savannah River Site High Level Waste Sludges, WSRC-TR-2005-00098, Savannah River Site, Aiken, SC 29808 (2005) 
16 Bibler N. E. and Fowler, J. R. Technical Basis for Eliminating Carbon - 14 as a Reportable Radionuclide in the DWPF Glass. WSRC-TR-2004-00629, Savannah River Site, Aiken, SC 29808 (2004)

17 Koopman, D.C. Comparison of Dow Corning 544 to IIT 747 Antifoam in the 1/240 SRAT. WSRC-TR-99-00377, Savannah River Site, Aiken, SC 29808 (1999) 


\subsection{ACKNOWLEDGEMENTS}

The authors wish to acknowledge all those who assisted in the performance of the work, especially: Shielded cells technicians and supervisors who performed the evaporation testing, ADS researchers and technicians who performed analysis of samples, and the technical reviewers of the report. 
WSRC-TR-2005-00309

Revision 0

APPENDIX A 
Revision 0

Evaporator Volume: $300 \mathrm{ml}$

Evaporator Diameter: $6 \mathrm{~cm}$

Top Ports: 4 \#7 Ace Threads

$124 / 40$ ground glass

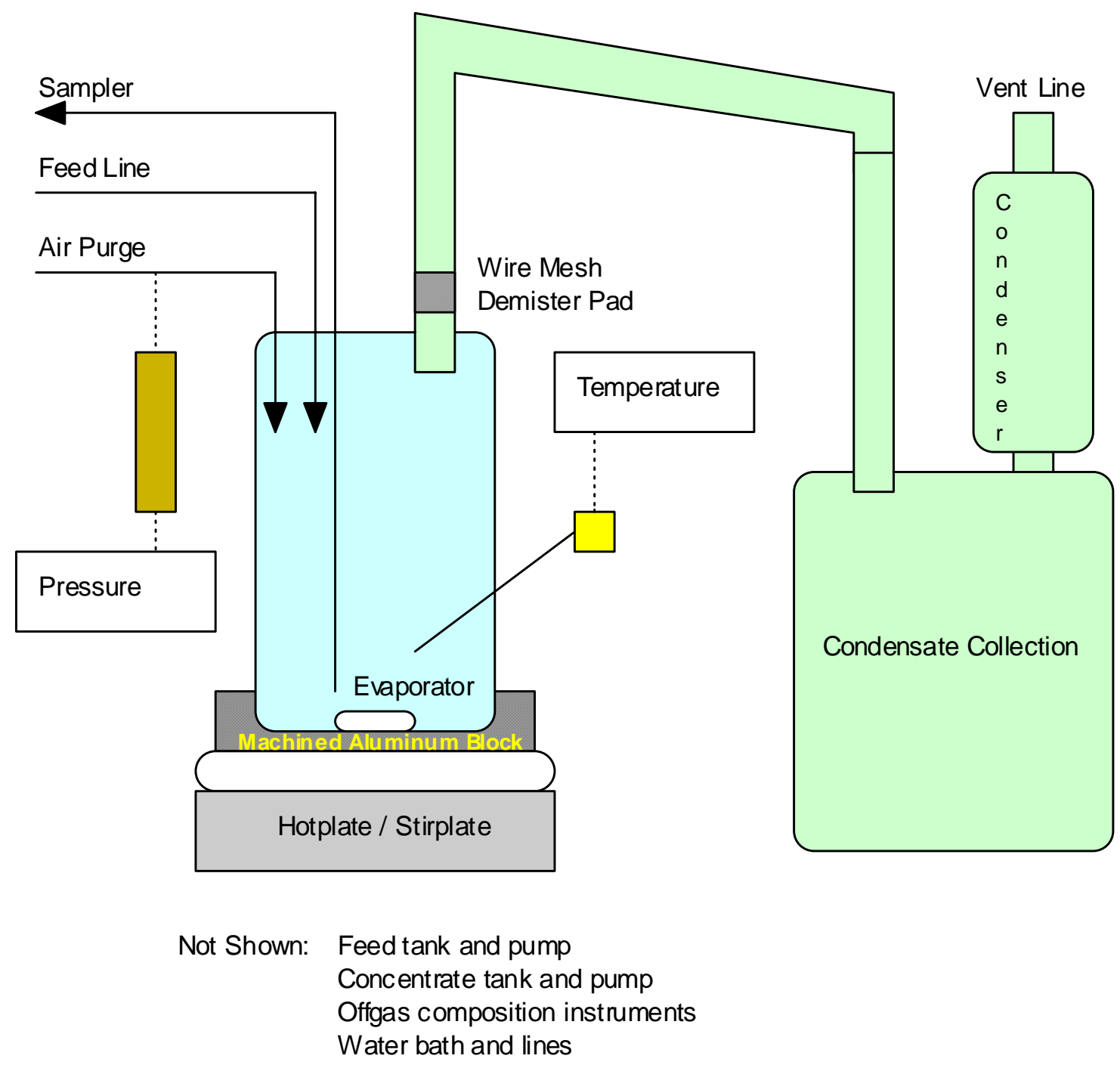

Figure A- 1. Evaporator Schematic 
Revision 0

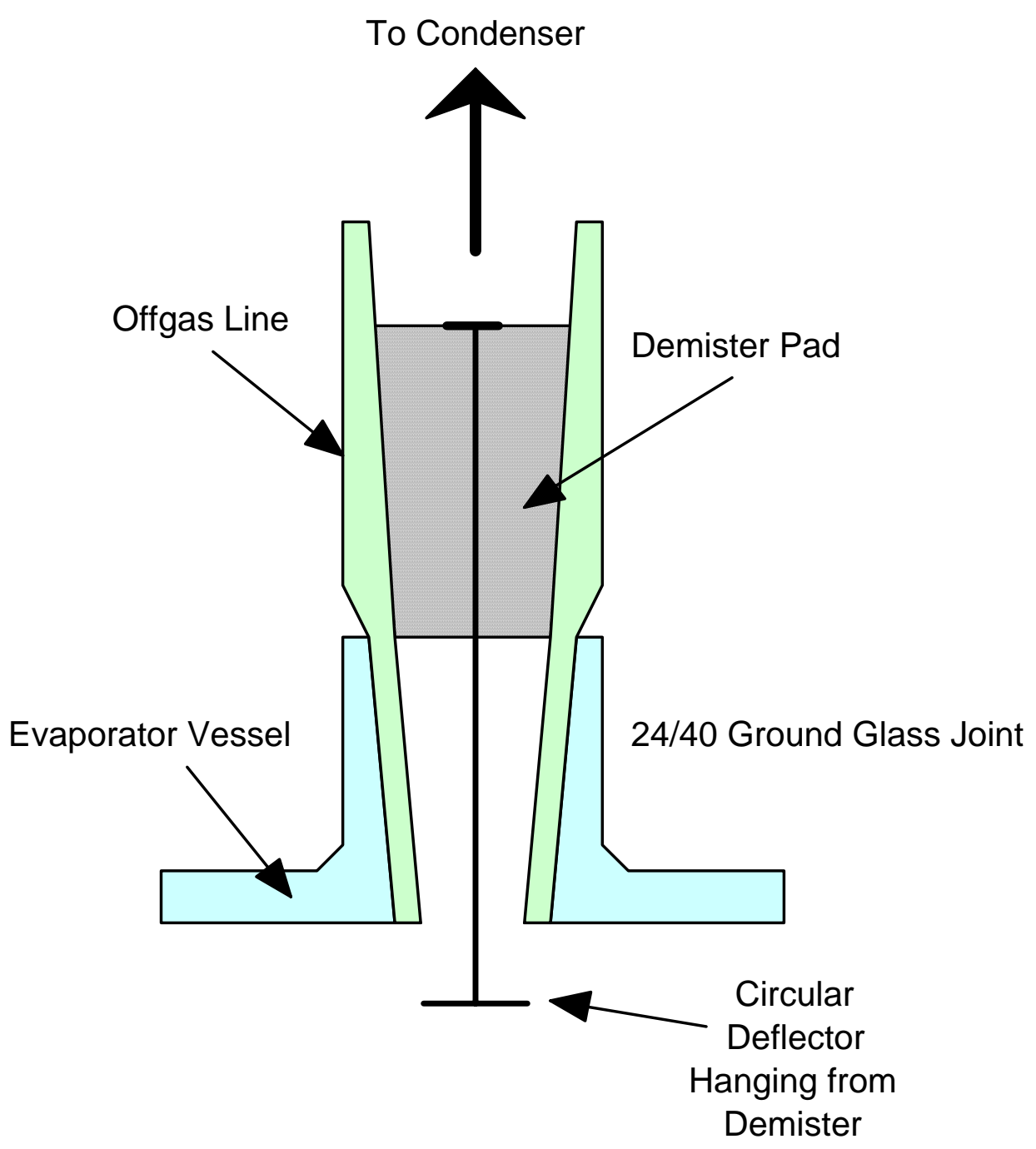

Figure A- 2. Demister and Deflector 
WSRC-TR-2005-00309

Revision 0

\section{APPENDIX B}


WSRC-TR-2005-00309

Revision 0

Table B- 1. Blended Feed Sample Results

\begin{tabular}{|c|c|c|c|c|}
\hline Category & Analyte & $\begin{array}{c}\text { Blended Feed } \\
\text { Average }\end{array}$ & STDEV & $\%$ RSD \\
\hline \multirow[t]{6}{*}{ Wt.\% Solids and Density } & Wt.\% Solids of Supernate & N.D. $^{a}$ & - & - \\
\hline & Wt. \% Total Solids of Slurry & 2.14E-01 & $1.48 \mathrm{E}-02$ & $6.88 \mathrm{E}+00$ \\
\hline & Wt.\% Insoluble Solids & $2.14 \mathrm{E}-01$ & $1.48 \mathrm{E}-02$ & $6.88 \mathrm{E}+00$ \\
\hline & Wt.\% Soluble Solids & N.D. ${ }^{a}$ & - & - \\
\hline & Slurry Density, g/mL & 1.01 & $3.68 \mathrm{E}-03$ & 3.66E-01 \\
\hline & Supernate Density, g/mL & 1.01 & $2.50 \mathrm{E}-03$ & $2.48 \mathrm{E}-01$ \\
\hline \multirow[t]{4}{*}{ Wet Chem } & Total Carbon, mg/L & $7.70 \mathrm{E}+01$ & $2.40 \mathrm{E}+00$ & $3.12 \mathrm{E}+00$ \\
\hline & Total Organic Carbon, mg/L & $7.70 \mathrm{E}+01$ & $2.40 \mathrm{E}+00$ & $3.12 \mathrm{E}+00$ \\
\hline & $\begin{array}{c}\text { Total Inorganic Carbon (i.e. } \\
\text { Carbonate), mg/L }\end{array}$ & $<1 \mathrm{E}+01$ & $0.00 \mathrm{E}+00$ & $0.00 \mathrm{E}+00$ \\
\hline & Particle Size & N.M. & - & - \\
\hline \multirow[t]{2}{*}{ Titration } & $\begin{array}{l}\text { Equivalents per Liter } \\
\text { Required for } \mathrm{pH}=7\end{array}$ & 2.85E-02 & 7.07E-04 & $2.48 \mathrm{E}+00$ \\
\hline & $\mathrm{pH}$ & 2.0 & 4.95E-02 & $2.46 \mathrm{E}+00$ \\
\hline \multirow[t]{9}{*}{\begin{tabular}{|c} 
IC Cation and Anions (mg/L \\
of supernate)
\end{tabular}} & Chloride & $4.00 \mathrm{E}+00$ & $1.41 \mathrm{E}+00$ & $3.54 \mathrm{E}+01$ \\
\hline & Fluoride & $4.00 \mathrm{E}+00$ & - & - \\
\hline & Nitrate & $1.82 \mathrm{E}+03$ & $1.41 \mathrm{E}+01$ & 7.77E-01 \\
\hline & Nitrite & $<1 \mathrm{E}+01$ & - & - \\
\hline & Oxalate & $<1 \mathrm{E}+01$ & - & - \\
\hline & Phosphate & $<1 \mathrm{E}+01$ & - & - \\
\hline & Sulfate & $2.65 \mathrm{E}+01$ & 7.07E-01 & $2.67 \mathrm{E}+00$ \\
\hline & Ammonium & $<1 \mathrm{E}+01$ & - & - \\
\hline & Formate & $1.95 \mathrm{E}+02$ & $4.95 \mathrm{E}+00$ & $2.54 \mathrm{E}+00$ \\
\hline \multirow[t]{25}{*}{$\begin{array}{c}\text { ICP-ES and AA Results } \\
(\mathrm{mg} / \mathrm{L})\end{array}$} & $\mathrm{Ag}$ & 3.23E-01 & 4.93E-03 & $1.53 \mathrm{E}+00$ \\
\hline & $\mathrm{Al}$ & $6.10 \mathrm{E}+01$ & $1.79 \mathrm{E}+00$ & $2.93 \mathrm{E}+00$ \\
\hline & $\mathrm{As}^{\mathrm{b}}$ & 4.95E-02 & - & - \\
\hline & B & $2.57 \mathrm{E}+00$ & $8.24 \mathrm{E}-02$ & $3.20 \mathrm{E}+00$ \\
\hline & $\mathrm{Ba}$ & $7.81 \mathrm{E}-01$ & $2.16 \mathrm{E}-02$ & $2.77 \mathrm{E}+00$ \\
\hline & $\mathrm{Be}$ & $3.62 \mathrm{E}-03$ & - & - \\
\hline & $\mathrm{Ca}$ & $9.09 \mathrm{E}+00$ & 6.65E-02 & $7.32 \mathrm{E}-01$ \\
\hline & $\mathrm{Cd}$ & $5.97 \mathrm{E}+00$ & 9.82E-02 & $1.64 \mathrm{E}+00$ \\
\hline & $\mathrm{Ce}$ & $1.32 \mathrm{E}+00$ & $2.62 \mathrm{E}-02$ & $1.98 \mathrm{E}+00$ \\
\hline & $\mathrm{Cr}$ & $1.55 \mathrm{E}+00$ & $1.56 \mathrm{E}-01$ & $1.01 \mathrm{E}+01$ \\
\hline & $\mathrm{Cu}$ & $9.14 \mathrm{E}-01$ & $2.49 \mathrm{E}-02$ & $2.72 \mathrm{E}+00$ \\
\hline & $\mathrm{Fe}$ & $4.70 \mathrm{E}+02$ & $1.22 \mathrm{E}+01$ & $2.61 \mathrm{E}+00$ \\
\hline & Gd & 4.86E-01 & 8.31E-03 & $1.71 \mathrm{E}+00$ \\
\hline & $\mathrm{Hg}^{\mathrm{b}}$ & $<1 \mathrm{E}-01$ & - & - \\
\hline & $\mathrm{K}^{\mathrm{b}}$ & 4.12E-01 & $3.45 \mathrm{E}-02$ & $8.38 \mathrm{E}+00$ \\
\hline & $\mathrm{Li}$ & $3.46 \mathrm{E}+00$ & 1.19E-01 & $3.44 \mathrm{E}+00$ \\
\hline & $\mathrm{Mg}$ & $2.89 \mathrm{E}+01$ & 5.62E-01 & $1.94 \mathrm{E}+00$ \\
\hline & $\mathrm{Mn}$ & $7.23 \mathrm{E}+01$ & $1.54 \mathrm{E}+00$ & $2.13 \mathrm{E}+00$ \\
\hline & Mo & $1.30 \mathrm{E}+00$ & 7.68E-03 & 5.92E-01 \\
\hline & $\mathrm{Na}$ & $7.71 \mathrm{E}+01$ & 1.68E-01 & $2.18 \mathrm{E}-01$ \\
\hline & $\mathrm{Ni}$ & $2.78 \mathrm{E}+01$ & $6.06 \mathrm{E}-01$ & $2.18 \mathrm{E}+00$ \\
\hline & $\mathrm{P}$ & $5.87 \mathrm{E}+00$ & 3.58E-02 & 6.09E-01 \\
\hline & $\mathrm{Pb}$ & $8.71 \mathrm{E}-01$ & 3.05E-02 & $3.50 \mathrm{E}+00$ \\
\hline & $\mathrm{S}$ & $8.42 \mathrm{E}+00$ & $3.41 \mathrm{E}-02$ & 4.05E-01 \\
\hline & $\mathrm{Sb}$ & $1.59 \mathrm{E}+00$ & 9.38E-03 & 5.92E-01 \\
\hline
\end{tabular}


WSRC-TR-2005-00309

Revision 0

\begin{tabular}{|c|c|c|c|c|}
\hline Category & Analyte & $\begin{array}{c}\text { Blended Feed } \\
\text { Average }\end{array}$ & STDEV & $\%$ RSD \\
\hline \multirow[t]{9}{*}{$\begin{array}{c}\text { ICP-ES and AA Results } \\
(\mathrm{mg} / \mathrm{L})\end{array}$} & $\mathrm{Se}^{\mathrm{b}}$ & $<5 \mathrm{E}-02$ & - & - \\
\hline & $\mathrm{Si}^{\mathrm{C}}$ & $1.81 \mathrm{E}+02$ & $1.07 \mathrm{E}+01$ & $5.95 \mathrm{E}+00$ \\
\hline & Sn & $2.41 \mathrm{E}+00$ & 3.58E-03 & 1.49E-01 \\
\hline & $\mathrm{Sr}$ & $2.00 \mathrm{E}+00$ & $1.91 \mathrm{E}-02$ & 9.52E-01 \\
\hline & $\mathrm{Ti}$ & 4.17E-01 & $1.10 \mathrm{E}-02$ & $2.65 \mathrm{E}+00$ \\
\hline & $\mathrm{U}$ & $3.35 \mathrm{E}+01$ & 8.39E-01 & $2.51 \mathrm{E}+00$ \\
\hline & $\mathrm{V}$ & $<2 \mathrm{E}-02$ & - & - \\
\hline & $\mathrm{Zn}$ & 9.69E-01 & 2.33E-02 & $2.41 \mathrm{E}+00$ \\
\hline & $\mathrm{Zr}$ & $1.79 \mathrm{E}+00$ & $2.08 \mathrm{E}-02$ & $1.16 \mathrm{E}+00$ \\
\hline \multirow[t]{6}{*}{ ICP-MS (mg/L) } & Co-59 & 1.79E-01 & $8.76 \mathrm{E}-03$ & $4.89 \mathrm{E}+00$ \\
\hline & La-139 & $2.98 \mathrm{E}-01$ & $1.36 \mathrm{E}-02$ & $4.56 \mathrm{E}+00$ \\
\hline & $\mathrm{Ru}^{\mathrm{e}}$ & 7.71E-01 & - & - \\
\hline & Rh-103 & 1.48E-01 & 5.22E-03 & $3.52 \mathrm{E}+00$ \\
\hline & $\mathrm{Pd}^{\mathrm{e}}$ & $2.88 \mathrm{E}-02$ & - & - \\
\hline & $\mathrm{Ag}^{\mathrm{e}}$ & 3.16E-01 & - & - \\
\hline \multirow[t]{34}{*}{$\begin{array}{c}\text { Counting and ICP-MS } \\
(\mathrm{d} / \mathrm{m} / \mathrm{mL})\end{array}$} & Alpha & $4.95 E+05$ & $2.40 \mathrm{E}+04$ & $4.86 \mathrm{E}+00$ \\
\hline & Beta & $2.04 \mathrm{E}+07$ & $9.07 \mathrm{E}+05$ & $4.45 \mathrm{E}+00$ \\
\hline & $\mathrm{H}-3$ & $<6 \mathrm{E}+02$ & - & - \\
\hline & C-14 & N.M. & - & - \\
\hline & Al-26 & $<9 \mathrm{E}+00$ & - & - \\
\hline & $\mathrm{Ni}-59$ & $3.65 E+03$ & $1.77 \mathrm{E}+02$ & $4.87 \mathrm{E}+00$ \\
\hline & Ni-63 & $4.02 \mathrm{E}+05$ & $3.07 \mathrm{E}+04$ & $7.65 \mathrm{E}+00$ \\
\hline & Co-60 & $7.93 \mathrm{E}+03$ & $5.33 \mathrm{E}+02$ & $6.72 \mathrm{E}+00$ \\
\hline & Se-79 & $1.80 \mathrm{E}+02^{\mathrm{d}}$ & - & - \\
\hline & Sr-90 & $7.96 \mathrm{E}+06$ & $2.42 \mathrm{E}+06$ & $3.04 \mathrm{E}+01$ \\
\hline & Nb-94 & $<4 \mathrm{E}+01$ & - & - \\
\hline & Tc-99 & $1.57 \mathrm{E}+03$ & $2.70 \mathrm{E}+01$ & $1.72 \mathrm{E}+00$ \\
\hline & Ru-106 & $<3 \mathrm{E}+02$ & - & - \\
\hline & Sb-125 & $5.24 \mathrm{E}+02$ & $6.86 \mathrm{E}+01$ & $1.31 \mathrm{E}+01$ \\
\hline & Sn-126 & $<4 \mathrm{E}+01$ & - & - \\
\hline & Sb-126 & $<4 \mathrm{E}+01$ & - & - \\
\hline & I-129 & $7.35 \mathrm{E}+00$ & $4.24 \mathrm{E}-02$ & 5.77E-01 \\
\hline & Cs-134 & $<1 \mathrm{E}+02$ & - & - \\
\hline & Cs-135 & $2.4 \mathrm{E}+00^{\mathrm{f}}$ & - & - \\
\hline & Cs-137 & $5.77 \mathrm{E}+05$ & $3.27 \mathrm{E}+04$ & $5.67 \mathrm{E}+00$ \\
\hline & Pm-147 & $3.90 \mathrm{E}+05$ & $1.03 \mathrm{E}+05$ & $2.65 \mathrm{E}+01$ \\
\hline & Sm-151 & $2.98 \mathrm{E}+05^{\mathrm{g}}$ & $5.76 \mathrm{E}+02$ & 1.93E-01 \\
\hline & Eu-154 & $1.57 \mathrm{E}+04$ & $1.74 \mathrm{E}+03$ & $1.11 \mathrm{E}+01$ \\
\hline & Eu-155 & $<7 \mathrm{E}+03$ & - & - \\
\hline & Ra-226 & $<1 \mathrm{E}+03$ & - & - \\
\hline & Th-230 & 4.36E-01 & - & - \\
\hline & Th-232 & 1.39E-01 & 7.62E-03 & $5.50 \mathrm{E}+00$ \\
\hline & U-233 & $1.04 \mathrm{E}+01^{\mathrm{d}}$ & - & - \\
\hline & U-234 & $2.82 \mathrm{E}+01$ & $1.24 \mathrm{E}-02$ & 4.39E-02 \\
\hline & U-235 & 8.40E-01 & $1.46 \mathrm{E}-02$ & $1.74 \mathrm{E}+00$ \\
\hline & U-236 & 7.53E-01 & 3.59E-02 & $4.77 \mathrm{E}+00$ \\
\hline & U-238 & $2.44 \mathrm{E}+01$ & $2.08 \mathrm{E}-01$ & 8.52E-01 \\
\hline & Np-237 & $5.44 \mathrm{E}+01$ & $2.52 \mathrm{E}+00$ & $4.63 \mathrm{E}+00$ \\
\hline & Pu-238 & $1.07 \mathrm{E}+05$ & $2.65 \mathrm{E}+03$ & $5.18 \mathrm{E}+00$ \\
\hline
\end{tabular}


WSRC-TR-2005-00309

Revision 0

\begin{tabular}{|c|c|c|c|c|}
\hline Category & Analyte & $\begin{array}{c}\text { Blended Feed } \\
\text { Average }\end{array}$ & STDEV & \%RSD \\
\hline $\begin{array}{c}\text { Counting and ICP-MS } \\
(\mathbf{d} / \mathbf{m} / \mathbf{m L})\end{array}$ & $\mathrm{Pu}-239$ & $5.12 \mathrm{E}+04$ & $2.65 \mathrm{E}+03$ & $5.18 \mathrm{E}+00$ \\
\hline & $\mathrm{Pu}-240$ & $1.75 \mathrm{E}+04$ & $1.11 \mathrm{E}+03$ & $6.33 \mathrm{E}+00$ \\
\hline & $\mathrm{Pu}-241$ & $2.29 \mathrm{E}+05$ & $9.08 \mathrm{E}+03$ & $3.97 \mathrm{E}+00$ \\
\hline & $\mathrm{Pu}-242$ & $1.30 \mathrm{E}+01$ & $4.10 \mathrm{E}-01$ & $3.16 \mathrm{E}+00$ \\
\hline & $\mathrm{Am}-241$ & $5.04 \mathrm{E}+04$ & $5.53 \mathrm{E}+03$ & $1.10 \mathrm{E}+01$ \\
\hline & $\mathrm{Am}-243$ & $3.61 \mathrm{E}+03$ & $1.26 \mathrm{E}+02$ & $3.50 \mathrm{E}+00$ \\
\hline & $\mathrm{Cm}-244$ & $2.29 \mathrm{E}+05$ & $3.44 \mathrm{E}+04$ & $1.50 \mathrm{E}+01$ \\
\hline
\end{tabular}

N.D. - Not Detected

N.M. - Not Measured

a Three measurements were completed. The results indicate that there were no solids per a three place balance

${ }^{\mathrm{b}}$ AA Results - As, CV Hg, K, and Se

${ }^{\mathrm{c}}$ Peroxide Fusion results

${ }^{\mathrm{d}}$ One value

e More than one isotope is used to calculate concentration. For example, masses 107 and 109 were added together for the Ag.

${ }^{\mathrm{f}}$ Calculation performed, See Table 5 .

${ }^{\mathrm{g}}$ Counting Data used for Sm-151

Table B- 2. Concentrate Sample Results

\begin{tabular}{|c|c|c|c|c|}
\hline Category & Analyte & $\begin{array}{c}\text { Concentrate } \\
\text { Average }\end{array}$ & STDEV & $\%$ RSD \\
\hline \multirow[t]{6}{*}{ Wt.\% Solids and Density } & Wt.\% Solids of Supernate & 3.84 & $6.70 \mathrm{E}-02$ & $1.74 \mathrm{E}+00$ \\
\hline & Wt. \% Total Solids of Slurry & 5.01 & $2.95 \mathrm{E}-01$ & $5.89 \mathrm{E}+00$ \\
\hline & Wt.\% Insoluble Solids & 1.22 & - & - \\
\hline & Wt.\% Soluble Solids & 3.93 & - & - \\
\hline & Slurry Density, g/mL & 1.08 & $1.19 \mathrm{E}-02$ & $1.10 \mathrm{E}+00$ \\
\hline & Supernate Density, g/mL & 1.05 & $5.20 \mathrm{E}-03$ & $4.96 \mathrm{E}-01$ \\
\hline \multirow[t]{4}{*}{ Wet Chem } & Total Carbon, mg/L & $4.73 \mathrm{E}+02$ & $1.72 \mathrm{E}+00$ & 3.64E-01 \\
\hline & Total Organic Carbon, mg/L & $4.73 \mathrm{E}+02$ & $1.72 \mathrm{E}+00$ & 3.64E-01 \\
\hline & $\begin{array}{c}\text { Total Inorganic Carbon (i.e. } \\
\text { Carbonate), mg/L }\end{array}$ & $<3 \mathrm{E}+02$ & - & - \\
\hline & Particle Size & N.M. & - & - \\
\hline \multirow[t]{2}{*}{ Titration } & $\begin{array}{l}\text { Equivalents per Liter } \\
\text { Required for } \mathrm{pH}=7\end{array}$ & $6.88 \mathrm{E}-01$ & 3.89E-02 & $5.66 \mathrm{E}+00$ \\
\hline & $\mathrm{pH}$ & 1.0 & $6.36 \mathrm{E}-02$ & $6.40 \mathrm{E}+00$ \\
\hline \multirow[t]{9}{*}{$\begin{array}{l}\text { IC Cation and Anions (mg/L } \\
\text { of supernate) }\end{array}$} & Chloride & $<6 \mathrm{E}+01$ & - & - \\
\hline & Fluoride & $9.51 \mathrm{E}+01$ & $5.02 \mathrm{E}-01$ & 5.28E-01 \\
\hline & Nitrate & $5.71 \mathrm{E}+04$ & $1.94 \mathrm{E}+03$ & $3.40 \mathrm{E}+00$ \\
\hline & Nitrite & $<3 \mathrm{E}+02$ & - & - \\
\hline & Oxalate & $<3 \mathrm{E}+02$ & - & - \\
\hline & Phosphate & $<3 \mathrm{E}+02$ & - & - \\
\hline & Sulfate & $6.03 \mathrm{E}+02$ & $3.18 \mathrm{E}+00$ & 5.28E-01 \\
\hline & Ammonium & $<3 \mathrm{E}+03$ & - & - \\
\hline & Formate & $3.49 \mathrm{E}+02$ & $4.30 \mathrm{E}+01$ & $1.23 \mathrm{E}+01$ \\
\hline \multirow[t]{5}{*}{$\begin{array}{l}\text { ICP-ES and AA Results } \\
(\mathrm{mg} / \mathrm{L})\end{array}$} & $\mathrm{Ag}$ & $9.62 \mathrm{E}+00$ & 3.50E-01 & $3.64 \mathrm{E}+00$ \\
\hline & $\mathrm{Al}$ & $1.34 \mathrm{E}+03$ & $5.65 \mathrm{E}+01$ & $4.21 \mathrm{E}+00$ \\
\hline & $\mathrm{As}^{\mathrm{a}}$ & $1.11 \mathrm{E}+00$ & 5.30E-02 & $4.77 \mathrm{E}+00$ \\
\hline & $\mathrm{B}$ & $7.85 \mathrm{E}+01$ & $2.23 \mathrm{E}+00$ & $2.84 \mathrm{E}+00$ \\
\hline & Ва & $1.79 \mathrm{E}+01$ & $3.39 \mathrm{E}-01$ & $1.90 \mathrm{E}+00$ \\
\hline
\end{tabular}


WSRC-TR-2005-00309

Revision 0

\begin{tabular}{|c|c|c|c|c|}
\hline Category & Analyte & $\begin{array}{c}\text { Concentrate } \\
\text { Average }\end{array}$ & STDEV & \%RSD \\
\hline & $\mathrm{Be}$ & $6.52 \mathrm{E}-02$ & $1.85 \mathrm{E}-03$ & $2.84 \mathrm{E}+00$ \\
\hline \multirow[t]{28}{*}{$\begin{array}{l}\text { ICP-ES and AA Results } \\
(\mathrm{mg} / \mathrm{L})\end{array}$} & $\mathrm{Ca}$ & $2.75 \mathrm{E}+02$ & $1.24 \mathrm{E}+01$ & $4.52 \mathrm{E}+00$ \\
\hline & $\mathrm{Cd}$ & $1.59 \mathrm{E}+02$ & $5.12 \mathrm{E}+00$ & $3.23 \mathrm{E}+00$ \\
\hline & $\mathrm{Ce}$ & $2.82 \mathrm{E}+01$ & $5.26 \mathrm{E}+00$ & $1.86 \mathrm{E}+01$ \\
\hline & $\mathrm{Cr}$ & $3.10 \mathrm{E}+01$ & $7.26 \mathrm{E}-01$ & $2.34 \mathrm{E}+00$ \\
\hline & $\mathrm{Cu}$ & $2.76 \mathrm{E}+01$ & $2.01 \mathrm{E}+00$ & $7.29 \mathrm{E}+00$ \\
\hline & $\mathrm{Fe}$ & $1.03 \mathrm{E}+04$ & $3.38 \mathrm{E}+02$ & $3.29 \mathrm{E}+00$ \\
\hline & Gd & $1.27 \mathrm{E}+01$ & $5.44 \mathrm{E}-01$ & $4.30 \mathrm{E}+00$ \\
\hline & $\mathrm{Hg}^{\mathrm{a}}$ & $2.99 \mathrm{E}+00^{\mathrm{C}}$ & - & - \\
\hline & $\mathrm{K}^{\mathrm{a}}$ & $1.30 \mathrm{E}+01$ & $6.25 \mathrm{E}-02$ & $4.82 \mathrm{E}-01$ \\
\hline & $\mathrm{Li}$ & $7.97 \mathrm{E}+01$ & $4.88 \mathrm{E}+00$ & $6.12 \mathrm{E}+00$ \\
\hline & Mg & $6.82 \mathrm{E}+02$ & $2.09 \mathrm{E}+01$ & $3.07 \mathrm{E}+00$ \\
\hline & Mn & $1.75 \mathrm{E}+03$ & $5.90 \mathrm{E}+01$ & $3.37 \mathrm{E}+00$ \\
\hline & Mo & $2.54 \mathrm{E}+01$ & $1.64 \mathrm{E}+00$ & $6.46 \mathrm{E}+00$ \\
\hline & $\mathrm{Na}$ & $2.28 \mathrm{E}+03$ & $1.26 \mathrm{E}+02$ & $5.53 \mathrm{E}+00$ \\
\hline & $\mathrm{Ni}$ & $6.11 \mathrm{E}+02$ & $2.04 \mathrm{E}+01$ & $3.34 \mathrm{E}+00$ \\
\hline & $\mathrm{P}$ & $1.36 \mathrm{E}+02$ & $4.94 \mathrm{E}+00$ & $3.63 \mathrm{E}+00$ \\
\hline & $\mathrm{Pb}$ & $2.35 \mathrm{E}+01$ & 8.70E-01 & $3.71 \mathrm{E}+00$ \\
\hline & $\mathrm{S}$ & $2.46 \mathrm{E}+02$ & $1.31 \mathrm{E}+01$ & $5.34 \mathrm{E}+00$ \\
\hline & $\mathrm{Sb}$ & $3.41 \mathrm{E}+01$ & $9.69 \mathrm{E}-01$ & $2.84 \mathrm{E}+00$ \\
\hline & $\mathrm{Se}^{\mathrm{a}}$ & $1.20 \mathrm{E}+00$ & - & - \\
\hline & $\mathrm{Si}^{\mathrm{b}}$ & $1.76 \mathrm{E}+03$ & $1.19 \mathrm{E}+01$ & 6.79E-01 \\
\hline & Sn & $4.93 \mathrm{E}+01$ & $4.32 \mathrm{E}+00$ & $8.76 \mathrm{E}+00$ \\
\hline & $\mathrm{Sr}$ & $5.98 \mathrm{E}+01$ & $2.93 \mathrm{E}+00$ & $4.90 \mathrm{E}+00$ \\
\hline & $\mathrm{Ti}$ & $9.77 \mathrm{E}+00$ & $3.54 \mathrm{E}-01$ & $3.63 \mathrm{E}+00$ \\
\hline & $\mathrm{U}$ & $1.13 \mathrm{E}+03$ & $4.29 \mathrm{E}+01$ & $3.79 \mathrm{E}+00$ \\
\hline & V & $5.99 \mathrm{E}+00$ & $2.09 \mathrm{E}+00$ & $3.49 \mathrm{E}+01$ \\
\hline & $\mathrm{Zn}$ & $2.44 \mathrm{E}+01$ & $1.31 \mathrm{E}+00$ & $5.36 \mathrm{E}+00$ \\
\hline & $\mathrm{Zr}$ & $3.26 \mathrm{E}+01$ & $4.77 \mathrm{E}+00$ & $1.46 \mathrm{E}+01$ \\
\hline \multirow[t]{6}{*}{ ICP-MS (mg/L) } & Co-59 & $3.89 \mathrm{E}+00$ & $6.27 \mathrm{E}-02$ & $1.61 \mathrm{E}+00$ \\
\hline & La-139 & $7.30 \mathrm{E}+00$ & $2.18 \mathrm{E}-01$ & $2.99 \mathrm{E}+00$ \\
\hline & $\mathrm{Ru}^{\mathrm{d}}$ & $1.85 \mathrm{E}+01$ & - & - \\
\hline & Rh-103 & $3.40 \mathrm{E}+00$ & 7.79E-03 & $2.29 \mathrm{E}-01$ \\
\hline & $\mathrm{Pd}^{\mathrm{d}}$ & 6.83E-01 & - & - \\
\hline & $\mathrm{Ag}^{\mathrm{d}}$ & $1.04 \mathrm{E}+01$ & - & - \\
\hline \multirow[t]{14}{*}{$\begin{array}{c}\text { Counting and ICP-MS } \\
(\mathrm{d} / \mathbf{m} / \mathbf{m L})\end{array}$} & Alpha & $1.61 \mathrm{E}+07$ & $1.36 \mathrm{E}+05$ & 8.43E-01 \\
\hline & Beta & $6.16 \mathrm{E}+08$ & $1.26 \mathrm{E}+07$ & $2.05 \mathrm{E}+00$ \\
\hline & $\mathrm{H}-3$ & $<2 \mathrm{E}+04^{\mathrm{e}}$ & - & - \\
\hline & $\mathrm{C}-14$ & N.M. & & \\
\hline & Al-26 & $<8.7 \mathrm{E}+03$ & - & - \\
\hline & $\mathrm{Ni}-59$ & $1 \mathrm{E}+05^{\mathrm{e}}$ & - & - \\
\hline & $\mathrm{Ni}-63$ & $1 \mathrm{E}+07^{\mathrm{e}}$ & - & - \\
\hline & Co-60 & $1.95 \mathrm{E}+05$ & $1.19 \mathrm{E}+04$ & $6.10 \mathrm{E}+00$ \\
\hline & Se-79 & $4.9 \mathrm{E}+04^{\mathrm{e}}$ & - & - \\
\hline & Sr-90 & $2.22 \mathrm{E}+08$ & $2.40 \mathrm{E}+07$ & $1.08 \mathrm{E}+01$ \\
\hline & Nb-94 & $<2.9 \mathrm{E}+04$ & - & - \\
\hline & Tc-99 & $3.87 \mathrm{E}+04$ & $9.15 \mathrm{E}+02$ & $2.36 \mathrm{E}+00$ \\
\hline & Ru-106 & $<3.5 \mathrm{E}+05$ & - & - \\
\hline & Sb-125 & $1.4 \mathrm{E}+04^{\mathrm{e}}$ & - & - \\
\hline
\end{tabular}


WSRC-TR-2005-00309

Revision 0

\begin{tabular}{|c|c|c|c|c|}
\hline Category & Analyte & $\begin{array}{c}\text { Concentrate } \\
\text { Average }\end{array}$ & STDEV & \%RSD \\
\hline \multirow[t]{27}{*}{$\begin{array}{c}\text { Counting and ICP-MS } \\
(\mathrm{d} / \mathrm{m} / \mathbf{m L})\end{array}$} & Sn-126 & $<3.7 \mathrm{E}+04$ & - & - \\
\hline & Sb-126 & $<3.7 \mathrm{E}+04$ & - & - \\
\hline & $\mathrm{I}-129$ & $2.0 \mathrm{E}+02^{\mathrm{e}}$ & - & - \\
\hline & Cs-134 & $<3.3 \mathrm{E}+04$ & - & - \\
\hline & Cs-135 & $8.3 \mathrm{E}+01^{\mathrm{e}}$ & - & - \\
\hline & Cs-137 & $1.97 \mathrm{E}+07$ & $3.80 \mathrm{E}+05$ & $1.93 \mathrm{E}+00$ \\
\hline & Pm-147 & $1.3 \mathrm{E}+07^{\mathrm{e}}$ & - & - \\
\hline & Sm-151 & $1.18 \mathrm{E}+07^{\mathrm{f}}$ & $1.03 \mathrm{E}+05$ & 8.76E-01 \\
\hline & Eu-154 & $5.16 \mathrm{E}+05$ & $4.96 \mathrm{E}+04$ & $9.60 \mathrm{E}+00$ \\
\hline & Eu-155 & $<1.9 \mathrm{E}+05$ & - & - \\
\hline & Ra-226 & $<1.4 \mathrm{E}+06$ & - & - \\
\hline & Th-230 & $5.09 \mathrm{E}+00$ & - & - \\
\hline & Th-232 & $3.50 \mathrm{E}+00$ & $2.69 \mathrm{E}-02$ & 7.68E-01 \\
\hline & U-233 & $7.01 \mathrm{E}+00$ & - & - \\
\hline & U-234 & $1.03 \mathrm{E}+03$ & $1.14 \mathrm{E}+01$ & $1.11 \mathrm{E}+00$ \\
\hline & U-235 & $3.22 \mathrm{E}+01$ & 3.08E-01 & 9.57E-01 \\
\hline & U-236 & $3.12 \mathrm{E}+01$ & 8.39E-01 & $2.69 \mathrm{E}+00$ \\
\hline & U-238 & $8.30 \mathrm{E}+02$ & $5.58 \mathrm{E}+01$ & $6.72 \mathrm{E}+00$ \\
\hline & $\mathrm{Np}-237$ & $2.05 \mathrm{E}+03$ & $1.55 \mathrm{E}+01$ & 7.59E-01 \\
\hline & $\mathrm{Pu}-238$ & $3.4 \mathrm{E}+06^{\mathrm{e}}$ & - & - \\
\hline & Pu-239 & $1.62 \mathrm{E}+06$ & $5.45 \mathrm{E}+04$ & $3.36 \mathrm{E}+00$ \\
\hline & $\mathrm{Pu}-240$ & $5.49 \mathrm{E}+05$ & $1.14 \mathrm{E}+04$ & $2.07 \mathrm{E}+00$ \\
\hline & Pu-241 & $7.2 \mathrm{E}+06^{\mathrm{e}}$ & - & - \\
\hline & $\mathrm{Pu}-242$ & $4.04 \mathrm{E}+02$ & $2.34 \mathrm{E}+01$ & $5.81 \mathrm{E}+00$ \\
\hline & Am-241 & $1.46 \mathrm{E}+06$ & $1.69 \mathrm{E}+05$ & $1.15 \mathrm{E}+01$ \\
\hline & Am-243 & $1.17 \mathrm{E}+05$ & $2.92 \mathrm{E}+03$ & $2.49 \mathrm{E}+00$ \\
\hline & Cm-244 & $9.47 \mathrm{E}+06$ & $9.86 \mathrm{E}+05$ & $1.04 \mathrm{E}+01$ \\
\hline
\end{tabular}

N.M. - Not Measured

${ }^{\text {a }}$ AA Results - As, CV Hg, K, and Se

${ }^{\mathrm{b}}$ Peroxide Fusion results

${ }^{\mathrm{c}}$ One value

${ }^{\mathrm{d}}$ More than one isotope is used to calculate concentration. For example, masses 107 and 109 were added together for the Ag.

e Calculation performed, See Table 5.

${ }^{\mathrm{f}}$ ICP-MS data used for Sm-151 
WSRC-TR-2005-00309

Revision 0

Table B- 3. Condensate Sample Results

\begin{tabular}{|c|c|c|c|c|}
\hline Category & Analyte & $\begin{array}{l}\text { Condensate } \\
\text { Average }\end{array}$ & STDEV & $\%$ RSD \\
\hline \multirow{6}{*}{ Wt.\% Solids and Density } & Wt.\% Solids of Supernate & N.D. ${ }^{a}$ & - & - \\
\hline & Wt. \% Total Solids of Slurry & N.D. ${ }^{a}$ & - & - \\
\hline & Wt.\% Insoluble Solids & - & - & - \\
\hline & Wt.\% Soluble Solids & - & - & - \\
\hline & Slurry Density, g/mL & - & - & - \\
\hline & Supernate Density, g/mL & 1.01 & $2.16 \mathrm{E}-03$ & $2.13 \mathrm{E}-01$ \\
\hline \multirow[t]{4}{*}{ Wet Chem } & Total Carbon, mg/L & $6.86 \mathrm{E}+01$ & $3.04 \mathrm{E}+00$ & $4.44 \mathrm{E}+00$ \\
\hline & Total Organic Carbon, mg/L & $6.86 \mathrm{E}+01$ & $3.04 \mathrm{E}+00$ & $4.44 \mathrm{E}+00$ \\
\hline & $\begin{array}{l}\text { Total Inorganic Carbon (i.e. } \\
\text { Carbonate), mg/L }\end{array}$ & $<1 \mathrm{E}+01$ & - & - \\
\hline & Particle Size & N.M. & & \\
\hline \multirow[t]{2}{*}{ Titration } & $\begin{array}{l}\text { Equivalents per Liter } \\
\text { Required for } \mathrm{pH}=7\end{array}$ & $6.45 \mathrm{E}-03$ & 4.95E-04 & $7.67 \mathrm{E}+00$ \\
\hline & $\mathrm{pH}$ & 3.2 & 4.95E-01 & $1.57 \mathrm{E}+01$ \\
\hline \multirow[t]{9}{*}{$\begin{array}{l}\text { IC Cation and Anions } \\
\text { (mg/L of supernate) }\end{array}$} & Chloride & $<3 \mathrm{E}+00$ & - & - \\
\hline & Fluoride & $<3 \mathrm{E}+00$ & - & - \\
\hline & Nitrate & $4.85 \mathrm{E}+01$ & $1.20 \mathrm{E}+01$ & $2.48 \mathrm{E}+01$ \\
\hline & Nitrite & $<1 \mathrm{E}+01$ & - & - \\
\hline & Oxalate & $<1 \mathrm{E}+01$ & - & - \\
\hline & Phosphate & $<1 \mathrm{E}+01$ & - & - \\
\hline & Sulfate & $5.00 \mathrm{E}+00$ & - & - \\
\hline & Ammonium & $<1 \mathrm{E}+01$ & - & - \\
\hline & Formate & $1.66 \mathrm{E}+02$ & $9.90 \mathrm{E}+00$ & $5.96 \mathrm{E}+00$ \\
\hline \multirow[t]{23}{*}{$\begin{array}{c}\text { ICP-ES and AA Results } \\
(\mathrm{mg} / \mathrm{L})\end{array}$} & $\mathrm{Ag}$ & $<1 \mathrm{E}-02$ & 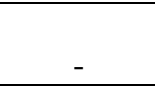 & (1) \\
\hline & $\mathrm{Al}$ & $1.61 \mathrm{E}-01$ & 2.83E-03 & $1.76 \mathrm{E}+00$ \\
\hline & $\mathrm{As}^{\mathrm{a}}$ & $<3 \mathrm{E}-02$ & - & - \\
\hline & $\mathrm{B}$ & $1.40 \mathrm{E}-01$ & $1.63 \mathrm{E}-02$ & $1.17 \mathrm{E}+01$ \\
\hline & $\mathrm{Ba}$ & $<3 \mathrm{E}-02$ & - & - \\
\hline & $\mathrm{Be}$ & $<2 \mathrm{E}-03$ & - & - \\
\hline & $\mathrm{Ca}$ & $8.25 \mathrm{E}-02$ & 6.43E-02 & $7.80 \mathrm{E}+01$ \\
\hline & $\mathrm{Cd}$ & $<5 \mathrm{E}-03$ & - & - \\
\hline & $\mathrm{Ce}$ & $<2 \mathrm{E}-01$ & - & - \\
\hline & $\mathrm{Cr}$ & $<3 \mathrm{E}-02$ & - & - \\
\hline & $\mathrm{Cu}$ & $<1 \mathrm{E}-02$ & - & - \\
\hline & $\mathrm{Fe}$ & 2.95E-02 & 9.19E-03 & $3.12 \mathrm{E}+01$ \\
\hline & Gd & $<2 \mathrm{E}-02$ & - & - \\
\hline & $\mathrm{Hg}^{\mathrm{a}}$ & $3.30 \mathrm{E}+00$ & $1.55 \mathrm{E}-01$ & $4.70 \mathrm{E}+00$ \\
\hline & $\mathrm{K}^{\mathrm{a}}$ & $<2 \mathrm{E}-01$ & - & - \\
\hline & $\mathrm{Li}$ & $<5 \mathrm{E}-02$ & - & - \\
\hline & $\mathrm{Mg}$ & $<4 \mathrm{E}-03$ & - & - \\
\hline & $\mathrm{Mn}$ & $<2 \mathrm{E}-03$ & - & - \\
\hline & Mo & $<2 \mathrm{E}-01$ & - & - \\
\hline & $\mathrm{Na}$ & $<4 \mathrm{E}-01$ & - & - \\
\hline & $\mathrm{Ni}$ & $<4 \mathrm{E}-02$ & - & - \\
\hline & $\mathrm{P}$ & $6.02 \mathrm{E}-01$ & 9.97E-02 & $1.66 \mathrm{E}+01$ \\
\hline & $\mathrm{Pb}$ & $<8 \mathrm{E}-01$ & - & - \\
\hline
\end{tabular}


WSRC-TR-2005-00309

Revision 0

\begin{tabular}{|c|c|c|c|c|}
\hline Category & Analyte & $\begin{array}{c}\text { Condensate } \\
\text { Average }\end{array}$ & STDEV & $\%$ RSD \\
\hline \multirow[t]{11}{*}{$\begin{array}{c}\text { ICP-ES and AA Results } \\
(\mathrm{mg} / \mathrm{L})\end{array}$} & $\mathrm{S}$ & 2.82E-01 & $2.28 \mathrm{E}-01$ & $8.07 \mathrm{E}+01$ \\
\hline & $\mathrm{Sb}$ & $<1 \mathrm{E}-01$ & - & - \\
\hline & $\mathrm{Se}^{\mathrm{a}}$ & $<6 \mathrm{E}-02$ & $0.00 \mathrm{E}+00$ & $0.00 \mathrm{E}+00$ \\
\hline & $\mathrm{Si}$ & $1.10 \mathrm{E}+01$ & $2.04 \mathrm{E}+00$ & $1.86 \mathrm{E}+01$ \\
\hline & Sn & $<3 \mathrm{E}-01$ & - & - \\
\hline & $\mathrm{Sr}$ & $<1 \mathrm{E}-02$ & - & - \\
\hline & $\mathrm{Ti}$ & $<3 \mathrm{E}-03$ & - & - \\
\hline & $\mathrm{U}$ & $<2 \mathrm{E}-01$ & - & - \\
\hline & $\mathrm{V}$ & $2.20 \mathrm{E}-02$ & - & - \\
\hline & $\mathrm{Zn}$ & 7.60E-02 & $4.38 \mathrm{E}-02$ & $5.77 \mathrm{E}+01$ \\
\hline & $\mathrm{Zr}$ & $<9 \mathrm{E}-03$ & - & - \\
\hline \multirow[t]{6}{*}{ ICP-MS (mg/L) } & Co-59 & $<2 \mathrm{E}-05$ & - & - \\
\hline & La-139 & $<2 \mathrm{E}-05$ & - & - \\
\hline & $\mathrm{Ru}^{\mathrm{b}}$ & $<9 \mathrm{E}-04$ & - & - \\
\hline & Rh-103 & $<5 \mathrm{E}-06$ & - & - \\
\hline & $\mathrm{Pd}^{\mathrm{b}}$ & $<2 \mathrm{E}-05$ & - & - \\
\hline & $\mathrm{Ag}^{\mathrm{b}}$ & $<4 \mathrm{E}-04$ & - & - \\
\hline \multirow[t]{32}{*}{$\begin{array}{c}\text { Counting and ICP-MS } \\
(\mathrm{d} / \mathrm{m} / \mathrm{mL})\end{array}$} & Alpha & $<4 \mathrm{E}+01$ & - & - \\
\hline & Beta & $1.55 \mathrm{E}+03$ & $4.95 \mathrm{E}+01$ & $3.20 \mathrm{E}+00$ \\
\hline & $\mathrm{H}-3$ & $<6 \mathrm{E}+02^{\mathrm{c}}$ & - & - \\
\hline & $\mathrm{C}-14$ & N.M. & - & - \\
\hline & Al-26 & $<3 \mathrm{E}-01$ & - & - \\
\hline & Ni-59 & $<6 \mathrm{E}+00^{\mathrm{c}}$ & - & - \\
\hline & $\mathrm{Ni}-63$ & $<6 \mathrm{E}+02^{\mathrm{c}}$ & - & - \\
\hline & Co-60 & 2.97E-01 & 3.96E-02 & $1.33 \mathrm{E}+01$ \\
\hline & Se-79 & $1.1 \mathrm{E}-02^{\mathrm{C}}$ & - & - \\
\hline & Sr-90 & $<2 \mathrm{E}+03$ & - & - \\
\hline & Nb-94 & $<3 \mathrm{E}-01$ & & \\
\hline & Tc-99 & $<7 \mathrm{E}+00$ & - & - \\
\hline & Ru-106 & $<2 \mathrm{E}+00$ & - & - \\
\hline & Sb-125 & $3.3 \mathrm{E}-02^{\mathrm{C}}$ & - & - \\
\hline & Sn-126 & $<8 \mathrm{E}-01$ & & \\
\hline & Sb-126 & $<3 \mathrm{E}-01$ & - & - \\
\hline & I-129 & $7.4 \mathrm{E}+00^{\mathrm{C}}$ & - & - \\
\hline & Cs-134 & $<3 \mathrm{E}-01$ & - & - \\
\hline & Cs-135 & $1.7 \mathrm{E}-04^{\mathrm{C}}$ & & \\
\hline & Cs-137 & $3.90 \mathrm{E}+01$ & $4.03 E+00$ & $1.03 \mathrm{E}+01$ \\
\hline & Pm-147 & $<4 \mathrm{E}+02^{\mathrm{c}}$ & & \\
\hline & Sm-151 & $<3 \mathrm{E}+02^{\mathrm{d}}$ & - & - \\
\hline & Eu-154 & 6.48E-01 & 3.68E-02 & $5.67 \mathrm{E}+00$ \\
\hline & Eu-155 & $<1 \mathrm{E} 00$ & - & - \\
\hline & Ra-226 & $<6 \mathrm{E}+00$ & - & - \\
\hline & Th-230 & $<2 \mathrm{E}-01$ & - & - \\
\hline & Th-232 & $<5 \mathrm{E}-06$ & - & - \\
\hline & U-233 & $<3 \mathrm{E}-01$ & - & - \\
\hline & U-234 & $<1 \mathrm{E}-01$ & - & - \\
\hline & U-235 & $<5 \mathrm{E}-05$ & - & - \\
\hline & U-236 & $<7 \mathrm{E}-04$ & - & - \\
\hline & U-238 & $1.72 \mathrm{E}-03$ & 4.97E-04 & $2.89 \mathrm{E}+01$ \\
\hline
\end{tabular}


WSRC-TR-2005-00309

Revision 0

\begin{tabular}{|c|c|c|c|c|}
\hline Category & Analyte & $\begin{array}{c}\text { Condensate } \\
\text { Average }\end{array}$ & STDEV & \%RSD \\
\hline $\begin{array}{c}\text { Counting and ICP-MS } \\
(\mathbf{d} / \mathbf{m} / \mathbf{m L})\end{array}$ & $\mathrm{Np}-237$ & $<8 \mathrm{E}-03$ & - & - \\
\hline & $\mathrm{Pu}-238$ & $<9 \mathrm{E}+00^{\mathrm{C}}$ & - & - \\
\hline & $\mathrm{Pu}-239$ & $<7 \mathrm{E}-01$ & - & - \\
\hline & $\mathrm{Pu}-240$ & $<5 \mathrm{E}+00$ & - & - \\
\hline & $\mathrm{Pu}-241$ & $<2 \mathrm{E}+01^{\mathrm{C}}$ & - & - \\
\hline & $\mathrm{Pu}-242$ & $<1 \mathrm{E}-01$ & - & - \\
\hline & $\mathrm{Am}-241$ & $<2 \mathrm{E}+00$ & - & - \\
\hline & $\mathrm{Am}-243$ & $<4 \mathrm{E}+00$ & - & - \\
\hline
\end{tabular}

N.D. - Not Detected

N.M. - Not Measured

${ }^{\mathrm{a}}$ AA Results - As, CV Hg, K, and Se

${ }^{\mathrm{b}}$ More than one isotope is used to calculate concentration. For example, masses 107 and 109 were added together for the Ag.

${ }^{\mathrm{c}}$ Calculation performed, See Table 5.

${ }^{\mathrm{d}}$ ICP-MS data used for Sm-151 


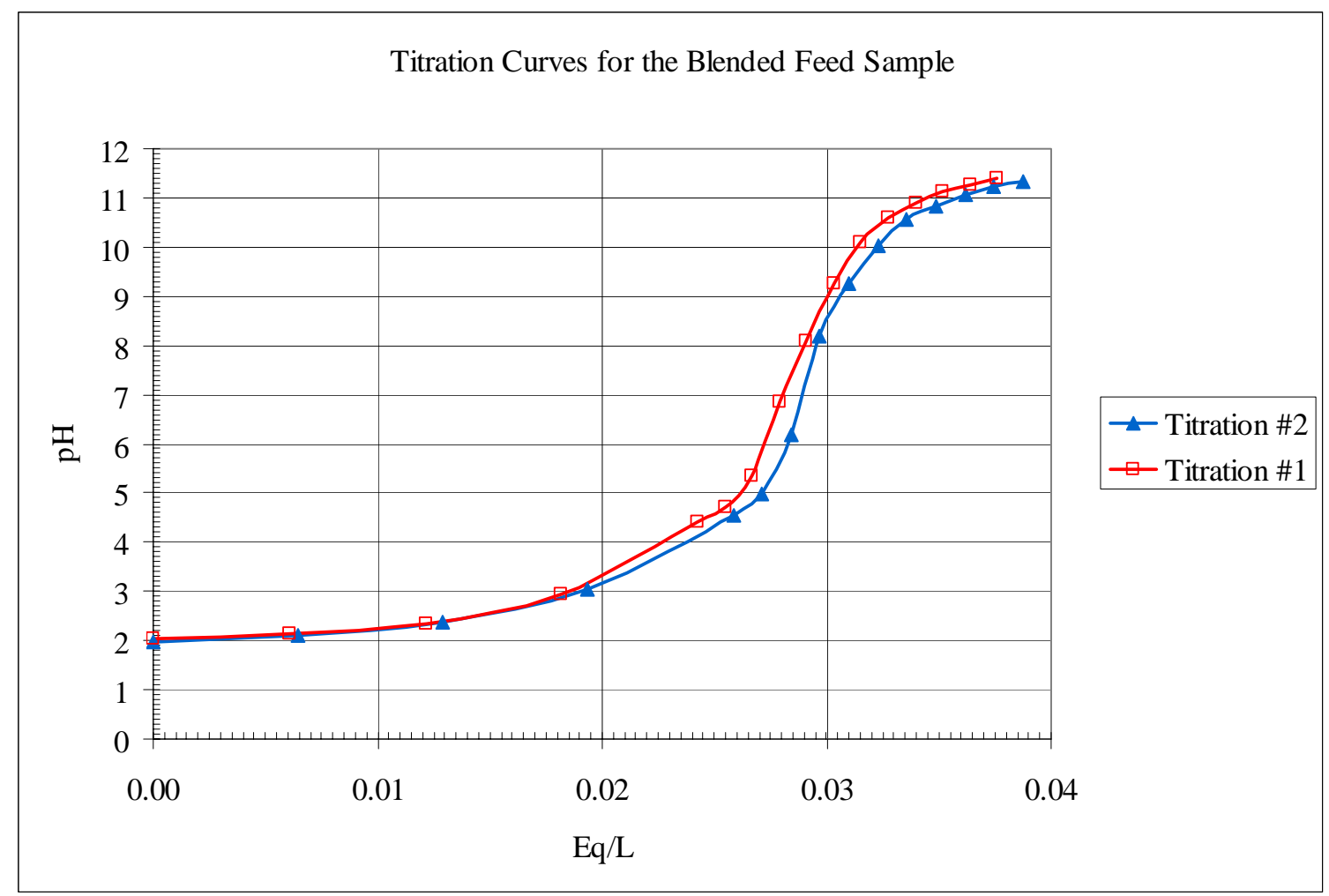

Figure B- 1. Blended Feed Titrations Results

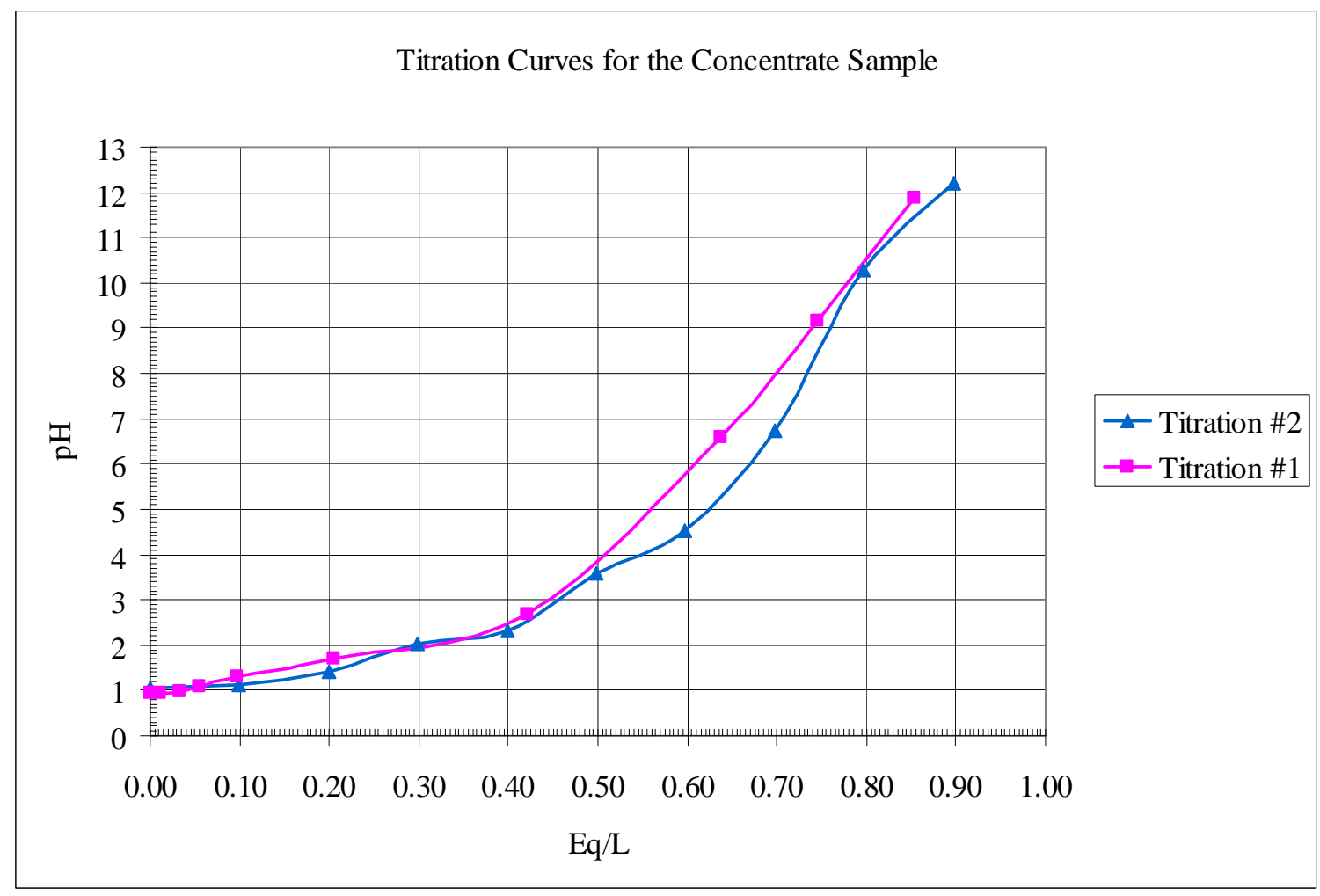

Figure B- 2. Concentrate Titrations Results 


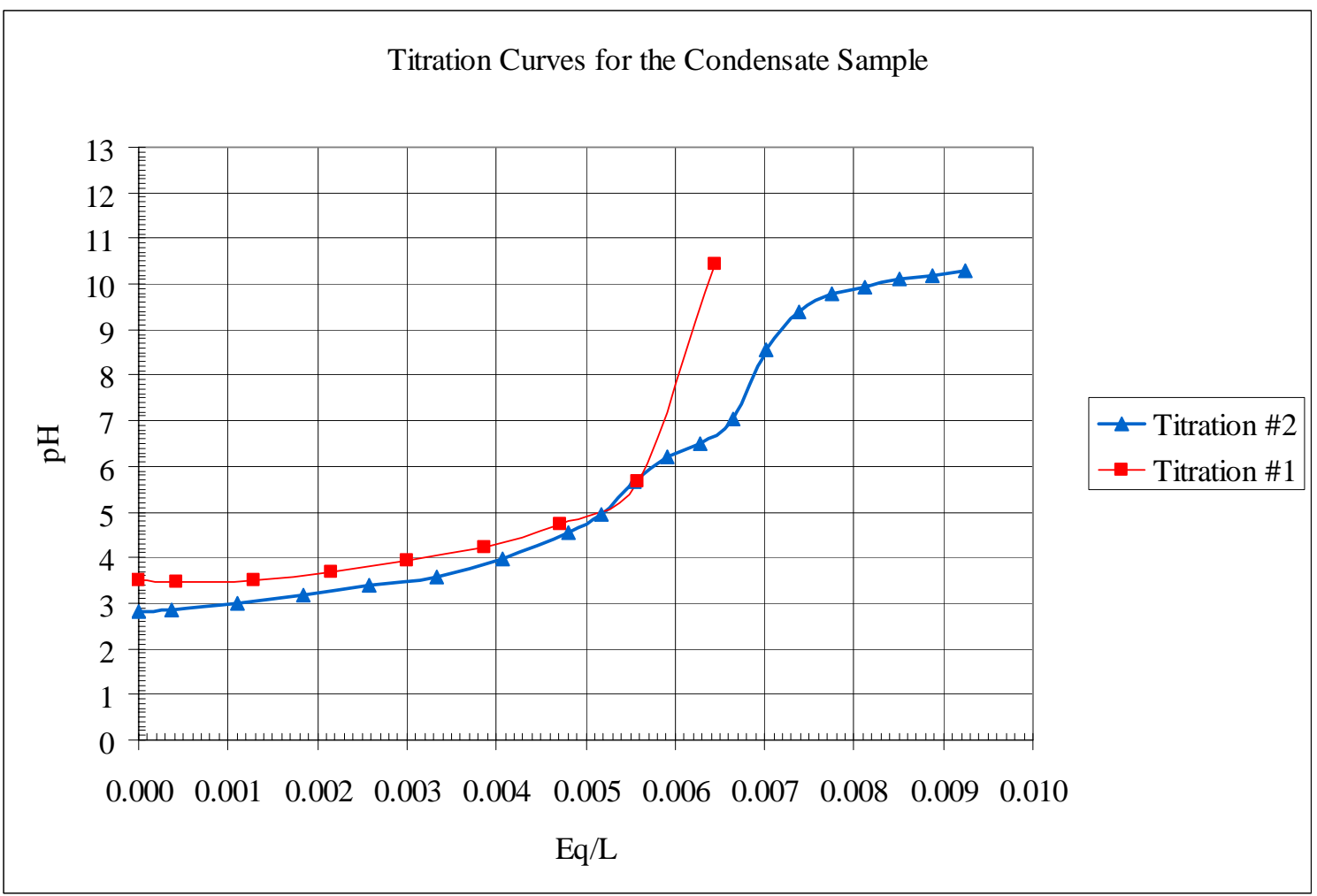

Figure B- 3. Condensate Titrations Results 
WSRC-TR-2005-00309

Revision 0

Table B- 4. Acid Evaporator Demonstration DF, CF, and Mass Balance Results

\begin{tabular}{|c|c|c|c|c|c|c|c|c|c|c|}
\hline Analyte & $\begin{array}{c}\text { Blended } \\
\text { Feed } \\
\end{array}$ & Concentrate & Condensate & $\begin{array}{c}\text { Blended } \\
\text { Feed }^{\mathrm{a}}\end{array}$ & Concentrate $^{\mathrm{b}}$ & Condensate $^{c}$ & $\begin{array}{l}\text { Concentrate } \\
+ \text { Condensate }\end{array}$ & $\begin{array}{c}\text { Ratio of } \\
\text { In vs. Out }\end{array}$ & $\begin{array}{c}\text { Decontamination } \\
\text { Factor for } \\
\text { Blended Feed and } \\
\text { Condensate } \\
\end{array}$ & $\begin{array}{c}\text { Concentration } \\
\text { Factor for } \\
\text { Blended Feed } \\
\text { and Concentrate }\end{array}$ \\
\hline Units & (mg/L) & (mg/L) & (mg/L) & (mg) & (mg) & (mg) & (mg) & & & \\
\hline Chloride & $4.00 \mathrm{E}+00$ & $6.00 \mathrm{E}+01$ & $3.00 \mathrm{E}+00$ & $1.23 \mathrm{E}+01$ & $5.27 \mathrm{E}+00$ & $8.29 \mathrm{E}+00$ & $1.36 \mathrm{E}+01$ & $9.09 \mathrm{E}-01$ & $1.33 \mathrm{E}+00$ & $1.50 \mathrm{E}+01$ \\
\hline Fluoride & $4.00 \mathrm{E}+00$ & $9.51 \mathrm{E}+01$ & $3.00 \mathrm{E}+00$ & $1.23 \mathrm{E}+01$ & $8.35 \mathrm{E}+00$ & $8.29 \mathrm{E}+00$ & $1.66 \mathrm{E}+01$ & 7.41E-01 & $1.33 \mathrm{E}+00$ & $2.38 \mathrm{E}+01$ \\
\hline Nitrate & $1.82 \mathrm{E}+03$ & $5.71 \mathrm{E}+04$ & $4.85 \mathrm{E}+01$ & $5.61 \mathrm{E}+03$ & $5.02 \mathrm{E}+03$ & $1.34 \mathrm{E}+02$ & $5.15 \mathrm{E}+03$ & $1.09 \mathrm{E}+00$ & $3.75 \mathrm{E}+01$ & $3.14 \mathrm{E}+01$ \\
\hline Nitrite & $1.00 \mathrm{E}+01$ & $3.00 \mathrm{E}+02$ & $1.00 \mathrm{E}+01$ & $3.08 \mathrm{E}+01$ & $2.64 \mathrm{E}+01$ & $2.76 \mathrm{E}+01$ & $5.40 \mathrm{E}+01$ & 5.71E-01 & $1.00 \mathrm{E}+00$ & $3.00 \mathrm{E}+01$ \\
\hline Oxalate & $1.00 \mathrm{E}+01$ & $3.00 \mathrm{E}+02$ & $1.00 \mathrm{E}+01$ & $3.08 \mathrm{E}+01$ & $2.64 \mathrm{E}+01$ & $2.76 \mathrm{E}+01$ & $5.40 \mathrm{E}+01$ & 5.71E-01 & $1.00 \mathrm{E}+00$ & $3.00 \mathrm{E}+01$ \\
\hline Phosphate & $1.00 \mathrm{E}+01$ & $3.00 \mathrm{E}+02$ & $1.00 \mathrm{E}+01$ & $3.08 \mathrm{E}+01$ & $2.64 \mathrm{E}+01$ & $2.76 \mathrm{E}+01$ & $5.40 \mathrm{E}+01$ & 5.71E-01 & $1.00 \mathrm{E}+00$ & $3.00 \mathrm{E}+01$ \\
\hline Sulfate & $2.65 \mathrm{E}+01$ & $6.03 \mathrm{E}+02$ & $5.00 \mathrm{E}+00$ & $8.17 \mathrm{E}+01$ & $5.30 \mathrm{E}+01$ & $1.38 \mathrm{E}+01$ & $6.68 \mathrm{E}+01$ & $1.22 \mathrm{E}+00$ & $5.30 \mathrm{E}+00$ & $2.28 \mathrm{E}+01$ \\
\hline Ammonium & $1.00 \mathrm{E}+01$ & $3.00 \mathrm{E}+03$ & $1.00 \mathrm{E}+01$ & $3.08 \mathrm{E}+01$ & $2.64 \mathrm{E}+02$ & $2.76 \mathrm{E}+01$ & $2.91 \mathrm{E}+02$ & $1.06 \mathrm{E}-01$ & $1.00 \mathrm{E}+00$ & $3.00 \mathrm{E}+02$ \\
\hline Formate & $1.95 \mathrm{E}+02$ & $3.49 \mathrm{E}+02$ & $1.66 \mathrm{E}+02$ & $6.01 \mathrm{E}+02$ & $3.07 \mathrm{E}+01$ & $4.59 \mathrm{E}+02$ & $4.90 \mathrm{E}+02$ & $1.23 \mathrm{E}+00$ & $1.17 \mathrm{E}+00$ & $1.79 \mathrm{E}+00$ \\
\hline $\mathrm{Ag}$ & 3.23E-01 & $9.62 \mathrm{E}+00$ & $1.00 \mathrm{E}-02$ & 9.96E-01 & 8.45E-01 & $2.76 \mathrm{E}-02$ & 8.73E-01 & $1.14 \mathrm{E}+00$ & $3.23 \mathrm{E}+01$ & $2.98 \mathrm{E}+01$ \\
\hline $\mathrm{Al}$ & $6.10 \mathrm{E}+01$ & $1.34 \mathrm{E}+03$ & $1.61 \mathrm{E}-01$ & $1.88 \mathrm{E}+02$ & $1.18 \mathrm{E}+02$ & $4.45 \mathrm{E}-01$ & $1.18 \mathrm{E}+02$ & $1.59 \mathrm{E}+00$ & $3.79 \mathrm{E}+02$ & $2.20 \mathrm{E}+01$ \\
\hline As & 4.95E-02 & $1.11 \mathrm{E}+00$ & 3.00E-02 & $1.53 \mathrm{E}-01$ & 9.75E-02 & 8.29E-02 & $1.80 \mathrm{E}-01$ & $8.46 \mathrm{E}-01$ & $1.65 \mathrm{E}+00$ & $2.24 \mathrm{E}+01$ \\
\hline $\mathrm{B}$ & $2.57 \mathrm{E}+00$ & $7.85 \mathrm{E}+01$ & $1.40 \mathrm{E}-01$ & $7.92 \mathrm{E}+00$ & $6.90 \mathrm{E}+00$ & $3.87 \mathrm{E}-01$ & $7.28 \mathrm{E}+00$ & $1.09 \mathrm{E}+00$ & $1.84 \mathrm{E}+01$ & $3.05 \mathrm{E}+01$ \\
\hline $\mathrm{Ba}$ & 7.81E-01 & $1.79 \mathrm{E}+01$ & 3.00E-02 & $2.41 \mathrm{E}+00$ & $1.57 \mathrm{E}+00$ & 8.29E-02 & $1.66 \mathrm{E}+00$ & $1.45 \mathrm{E}+00$ & $2.60 \mathrm{E}+01$ & $2.29 \mathrm{E}+01$ \\
\hline $\mathrm{Be}$ & 3.62E-03 & 6.52E-02 & 2.00E-03 & 1.12E-02 & 5.73E-03 & 5.53E-03 & 1.13E-02 & 9.91E-01 & $1.81 \mathrm{E}+00$ & $1.80 \mathrm{E}+01$ \\
\hline $\mathrm{Ca}$ & $9.09 \mathrm{E}+00$ & $2.75 \mathrm{E}+02$ & 8.25E-02 & $2.80 \mathrm{E}+01$ & $2.42 \mathrm{E}+01$ & $2.28 \mathrm{E}-01$ & $2.44 \mathrm{E}+01$ & $1.15 \mathrm{E}+00$ & $1.10 \mathrm{E}+02$ & $3.03 \mathrm{E}+01$ \\
\hline $\mathrm{Cd}$ & $5.97 \mathrm{E}+00$ & $1.59 \mathrm{E}+02$ & $5.00 \mathrm{E}-03$ & $1.84 \mathrm{E}+01$ & $1.40 \mathrm{E}+01$ & $1.38 \mathrm{E}-02$ & $1.40 \mathrm{E}+01$ & $1.32 \mathrm{E}+00$ & $1.19 \mathrm{E}+03$ & $2.66 \mathrm{E}+01$ \\
\hline $\mathrm{Ce}$ & $1.32 \mathrm{E}+00$ & $2.82 \mathrm{E}+01$ & $2.00 \mathrm{E}-01$ & $4.07 \mathrm{E}+00$ & $2.48 \mathrm{E}+00$ & 5.53E-01 & $3.03 E+00$ & $1.34 \mathrm{E}+00$ & $6.60 \mathrm{E}+00$ & $2.14 \mathrm{E}+01$ \\
\hline $\mathrm{Cr}$ & $1.55 \mathrm{E}+00$ & $3.10 \mathrm{E}+01$ & 3.00E-02 & $4.78 \mathrm{E}+00$ & $2.72 \mathrm{E}+00$ & 8.29E-02 & $2.81 \mathrm{E}+00$ & $1.70 \mathrm{E}+00$ & $5.17 \mathrm{E}+01$ & $2.00 \mathrm{E}+01$ \\
\hline $\mathrm{Cu}$ & 9.14E-01 & $2.76 \mathrm{E}+01$ & 1.00E-02 & $2.82 \mathrm{E}+00$ & $2.42 \mathrm{E}+00$ & $2.76 \mathrm{E}-02$ & $2.45 \mathrm{E}+00$ & $1.15 \mathrm{E}+00$ & $9.14 \mathrm{E}+01$ & $3.02 \mathrm{E}+01$ \\
\hline $\mathrm{Fe}$ & $4.70 \mathrm{E}+02$ & $1.03 \mathrm{E}+04$ & 2.95E-02 & $1.45 \mathrm{E}+03$ & $9.05 \mathrm{E}+02$ & 8.16E-02 & $9.05 \mathrm{E}+02$ & $1.60 \mathrm{E}+00$ & $1.59 \mathrm{E}+04$ & $2.19 \mathrm{E}+01$ \\
\hline $\mathrm{Gd}$ & 4.86E-01 & $1.27 \mathrm{E}+01$ & 2.00E-02 & $1.50 \mathrm{E}+00$ & $1.12 \mathrm{E}+00$ & 5.53E-02 & $1.17 \mathrm{E}+00$ & $1.28 \mathrm{E}+00$ & $2.43 E+01$ & $2.61 \mathrm{E}+01$ \\
\hline $\mathrm{Hg}$ & 1.00E-01 & $2.99 \mathrm{E}+00$ & $3.30 \mathrm{E}+00$ & 3.08E-01 & 2.63E-01 & $9.12 \mathrm{E}+00$ & $9.39 \mathrm{E}+00$ & $3.28 \mathrm{E}-02$ & 3.03E-02 & $2.99 \mathrm{E}+01$ \\
\hline $\mathrm{K}$ & 4.12E-01 & $1.30 \mathrm{E}+01$ & 2.00E-01 & $1.27 \mathrm{E}+00$ & $1.14 \mathrm{E}+00$ & 5.53E-01 & $1.69 \mathrm{E}+00$ & 7.49E-01 & $2.06 \mathrm{E}+00$ & $3.16 \mathrm{E}+01$ \\
\hline $\mathrm{Li}$ & $3.46 \mathrm{E}+00$ & $7.97 \mathrm{E}+01$ & $5.00 \mathrm{E}-02$ & $1.07 \mathrm{E}+01$ & $7.00 \mathrm{E}+00$ & $1.38 \mathrm{E}-01$ & $7.14 \mathrm{E}+00$ & $1.49 \mathrm{E}+00$ & $6.92 \mathrm{E}+01$ & $2.30 \mathrm{E}+01$ \\
\hline $\mathrm{Mg}$ & $2.89 \mathrm{E}+01$ & $6.82 \mathrm{E}+02$ & 4.00E-03 & $8.91 \mathrm{E}+01$ & $5.99 \mathrm{E}+01$ & $1.11 \mathrm{E}-02$ & $5.99 \mathrm{E}+01$ & $1.49 \mathrm{E}+00$ & $7.23 E+03$ & $2.36 \mathrm{E}+01$ \\
\hline $\mathrm{Mn}$ & $7.23 \mathrm{E}+01$ & $1.75 \mathrm{E}+03$ & 2.00E-03 & $2.23 \mathrm{E}+02$ & $1.54 \mathrm{E}+02$ & 5.53E-03 & $1.54 \mathrm{E}+02$ & $1.45 \mathrm{E}+00$ & $3.62 \mathrm{E}+04$ & $2.42 \mathrm{E}+01$ \\
\hline Mo & $1.30 \mathrm{E}+00$ & $2.54 \mathrm{E}+01$ & 2.00E-01 & $4.01 \mathrm{E}+00$ & $2.23 \mathrm{E}+00$ & 5.53E-01 & $2.78 \mathrm{E}+00$ & $1.44 \mathrm{E}+00$ & $6.50 \mathrm{E}+00$ & $1.95 \mathrm{E}+01$ \\
\hline $\mathrm{Na}$ & $7.71 \mathrm{E}+01$ & $2.28 \mathrm{E}+03$ & 4.00E-01 & $2.38 \mathrm{E}+02$ & $2.00 \mathrm{E}+02$ & $1.11 \mathrm{E}+00$ & $2.01 \mathrm{E}+02$ & $1.18 \mathrm{E}+00$ & $1.93 \mathrm{E}+02$ & $2.96 \mathrm{E}+01$ \\
\hline $\mathrm{Ni}$ & $2.78 \mathrm{E}+01$ & $6.11 \mathrm{E}+02$ & 4.00E-02 & $8.57 \mathrm{E}+01$ & $5.37 \mathrm{E}+01$ & $1.11 \mathrm{E}-01$ & $5.38 \mathrm{E}+01$ & $1.59 \mathrm{E}+00$ & $6.95 E+02$ & $2.20 \mathrm{E}+01$ \\
\hline $\mathrm{P}$ & $5.87 \mathrm{E}+00$ & $1.36 \mathrm{E}+02$ & $6.02 \mathrm{E}-01$ & $1.81 \mathrm{E}+01$ & $1.19 \mathrm{E}+01$ & $1.66 \mathrm{E}+00$ & $1.36 \mathrm{E}+01$ & $1.33 \mathrm{E}+00$ & $9.75 \mathrm{E}+00$ & $2.32 \mathrm{E}+01$ \\
\hline
\end{tabular}


WSRC-TR-2005-00309

Revision 0

\begin{tabular}{|c|c|c|c|c|c|c|c|c|c|c|}
\hline Analyte & $\begin{array}{c}\text { Blended } \\
\text { Feed }\end{array}$ & Concentrate & Condensate & $\begin{array}{l}\text { Blended } \\
\text { Feed }^{\mathrm{a}}\end{array}$ & Concentrate $^{\mathrm{b}}$ & Condensate $^{c}$ & $\begin{array}{l}\text { Concentrate } \\
\text { +Condensate }\end{array}$ & $\begin{array}{c}\text { Ratio of } \\
\text { In vs. Out }\end{array}$ & $\begin{array}{c}\text { Decontamination } \\
\text { Factor for } \\
\text { Blended Feed and } \\
\text { Condensate }\end{array}$ & $\begin{array}{c}\text { Concentration } \\
\text { Factor for } \\
\text { Blended Feed } \\
\text { and Concentrate }\end{array}$ \\
\hline Units & $(\mathrm{mg} / \mathrm{L})$ & $(\mathrm{mg} / \mathrm{L})$ & $(\mathrm{mg} / \mathrm{L})$ & (mg) & (mg) & (mg) & (mg) & & & \\
\hline $\mathrm{Pb}$ & $8.71 \mathrm{E}-01$ & $2.35 \mathrm{E}+01$ & 8.00E-01 & $2.69 \mathrm{E}+00$ & $2.06 \mathrm{E}+00$ & $2.21 \mathrm{E}+00$ & $4.28 \mathrm{E}+00$ & $6.28 \mathrm{E}-01$ & $1.09 \mathrm{E}+00$ & $2.70 \mathrm{E}+01$ \\
\hline $\mathrm{S}$ & $8.42 \mathrm{E}+00$ & $2.46 \mathrm{E}+02$ & $2.82 \mathrm{E}-01$ & $2.60 \mathrm{E}+01$ & $2.16 \mathrm{E}+01$ & $7.80 \mathrm{E}-01$ & $2.24 \mathrm{E}+01$ & $1.16 \mathrm{E}+00$ & $2.99 \mathrm{E}+01$ & $2.92 \mathrm{E}+01$ \\
\hline $\mathrm{Sb}$ & $1.59 \mathrm{E}+00$ & $3.41 \mathrm{E}+01$ & $1.00 \mathrm{E}-01$ & $4.90 \mathrm{E}+00$ & $3.00 \mathrm{E}+00$ & $2.76 \mathrm{E}-01$ & $3.27 \mathrm{E}+00$ & $1.50 \mathrm{E}+00$ & $1.59 \mathrm{E}+01$ & $2.14 \mathrm{E}+01$ \\
\hline Se & $5.00 \mathrm{E}-02$ & $1.20 \mathrm{E}+00$ & 6.00E-02 & $1.54 \mathrm{E}-01$ & $1.05 \mathrm{E}-01$ & $1.66 \mathrm{E}-01$ & $2.71 \mathrm{E}-01$ & $5.68 \mathrm{E}-01$ & 8.33E-01 & $2.40 \mathrm{E}+01$ \\
\hline $\mathrm{Si}$ & $1.81 \mathrm{E}+02$ & $1.76 \mathrm{E}+03$ & $1.10 \mathrm{E}+01$ & $5.58 \mathrm{E}+02$ & $1.55 \mathrm{E}+02$ & $3.04 \mathrm{E}+01$ & $1.85 \mathrm{E}+02$ & $3.02 \mathrm{E}+00$ & $1.65 \mathrm{E}+01$ & $9.72 \mathrm{E}+00$ \\
\hline $\mathrm{Sn}$ & $2.41 \mathrm{E}+00$ & $4.93 \mathrm{E}+01$ & 3.00E-01 & $7.43 \mathrm{E}+00$ & $4.33 \mathrm{E}+00$ & 8.29E-01 & $5.16 \mathrm{E}+00$ & $1.44 \mathrm{E}+00$ & $8.03 E+00$ & $2.05 \mathrm{E}+01$ \\
\hline $\mathrm{Sr}$ & $2.00 \mathrm{E}+00$ & $5.98 \mathrm{E}+01$ & $1.00 \mathrm{E}-02$ & $6.17 \mathrm{E}+00$ & $5.25 \mathrm{E}+00$ & $2.76 \mathrm{E}-02$ & $5.28 \mathrm{E}+00$ & $1.17 \mathrm{E}+00$ & $2.00 \mathrm{E}+02$ & $2.99 \mathrm{E}+01$ \\
\hline $\mathrm{Ti}$ & 4.17E-01 & $9.77 \mathrm{E}+00$ & 3.00E-03 & $1.29 \mathrm{E}+00$ & 8.58E-01 & 8.29E-03 & 8.67E-01 & $1.48 \mathrm{E}+00$ & $1.39 \mathrm{E}+02$ & $2.34 \mathrm{E}+01$ \\
\hline $\mathrm{U}$ & $3.35 E+01$ & $1.13 E+03$ & $2.00 \mathrm{E}-01$ & $1.03 \mathrm{E}+02$ & $9.93 \mathrm{E}+01$ & 5.53E-01 & $9.98 \mathrm{E}+01$ & $1.03 \mathrm{E}+00$ & $1.68 \mathrm{E}+02$ & $3.37 E+01$ \\
\hline $\mathrm{V}$ & $2.00 \mathrm{E}-02$ & $5.99 \mathrm{E}+00$ & $2.20 \mathrm{E}-02$ & 6.17E-02 & $5.26 \mathrm{E}-01$ & $6.08 \mathrm{E}-02$ & 5.87E-01 & $1.05 \mathrm{E}-01$ & $9.09 \mathrm{E}-01$ & $3.00 \mathrm{E}+02$ \\
\hline $\mathrm{Zn}$ & 9.69E-01 & $2.44 \mathrm{E}+01$ & 7.60E-02 & $2.99 \mathrm{E}+00$ & $2.14 \mathrm{E}+00$ & $2.10 \mathrm{E}-01$ & $2.35 \mathrm{E}+00$ & $1.27 \mathrm{E}+00$ & $1.28 \mathrm{E}+01$ & $2.52 \mathrm{E}+01$ \\
\hline $\mathrm{Zr}$ & $1.79 \mathrm{E}+00$ & $3.26 \mathrm{E}+01$ & $9.00 \mathrm{E}-03$ & $5.52 \mathrm{E}+00$ & $2.86 \mathrm{E}+00$ & $2.49 \mathrm{E}-02$ & $2.89 \mathrm{E}+00$ & $1.91 \mathrm{E}+00$ & $1.99 \mathrm{E}+02$ & $1.82 \mathrm{E}+01$ \\
\hline Co-59 & $1.79 \mathrm{E}-01$ & $3.89 \mathrm{E}+00$ & $2.00 \mathrm{E}-05$ & 5.52E-01 & $3.42 \mathrm{E}-01$ & $5.53 \mathrm{E}-05$ & $3.42 \mathrm{E}-01$ & $1.61 \mathrm{E}+00$ & $8.95 \mathrm{E}+03$ & $2.17 \mathrm{E}+01$ \\
\hline $\mathrm{La}$ & 2.98E-01 & $7.30 \mathrm{E}+00$ & $2.00 \mathrm{E}-05$ & 9.19E-01 & $6.41 \mathrm{E}-01$ & 5.53E-05 & $6.41 \mathrm{E}-01$ & $1.43 \mathrm{E}+00$ & $1.49 \mathrm{E}+04$ & $2.45 \mathrm{E}+01$ \\
\hline Ruthenium & 7.71E-01 & $1.85 \mathrm{E}+01$ & 9.00E-04 & $2.38 \mathrm{E}+00$ & $1.63 \mathrm{E}+00$ & $2.49 \mathrm{E}-03$ & $1.63 \mathrm{E}+00$ & $1.46 \mathrm{E}+00$ & $8.57 \mathrm{E}+02$ & $2.40 \mathrm{E}+01$ \\
\hline Rhodium & $1.48 \mathrm{E}-01$ & $3.40 \mathrm{E}+00$ & 5.00E-06 & $4.56 \mathrm{E}-01$ & $2.99 \mathrm{E}-01$ & $1.38 \mathrm{E}-05$ & $2.99 \mathrm{E}-01$ & $1.53 \mathrm{E}+00$ & $2.96 \mathrm{E}+04$ & $2.30 \mathrm{E}+01$ \\
\hline Palladium & $2.88 \mathrm{E}-02$ & 6.83E-01 & 2.00E-05 & 8.88E-02 & 6.00E-02 & 5.53E-05 & 6.01E-02 & $1.48 \mathrm{E}+00$ & $1.44 \mathrm{E}+03$ & $2.37 \mathrm{E}+01$ \\
\hline Silver & $3.16 \mathrm{E}-01$ & $1.04 \mathrm{E}+01$ & 4.00E-04 & $9.74 \mathrm{E}-01$ & $9.14 \mathrm{E}-01$ & $1.11 \mathrm{E}-03$ & $9.15 \mathrm{E}-01$ & $1.06 \mathrm{E}+00$ & $7.90 \mathrm{E}+02$ & $3.29 \mathrm{E}+01$ \\
\hline Analyte & $\begin{array}{c}\text { Blended } \\
\text { Feed } \\
\end{array}$ & Concentrate & Condensate & $\begin{array}{c}\text { Blended } \\
\text { Feed }^{\mathrm{a}} \\
\end{array}$ & Concentrate $^{\text {b }}$ & Condensate $^{c}$ & $\begin{array}{c}\text { Concentrate } \\
+ \text { Condensate } \\
\end{array}$ & $\begin{array}{c}\text { Ratio of } \\
\text { In vs. Out }\end{array}$ & $\begin{array}{l}\text { Decontamination } \\
\text { Factor for } \\
\text { Blended Feed and } \\
\text { Condensate } \\
\end{array}$ & $\begin{array}{c}\text { Concentration } \\
\text { Factor for } \\
\text { Blended Feed } \\
\text { and Concentrate } \\
\end{array}$ \\
\hline Units & $(\mathrm{d} / \mathrm{m} / \mathrm{mL})$ & $(d / \mathbf{m} / \mathbf{m L})$ & $(d / \mathbf{m} / \mathbf{m L})$ & $(d / \mathbf{m})$ & $(d / \mathbf{m})$ & $(d / \mathbf{m})$ & $(d / \mathbf{m})$ & & & \\
\hline Alpha & $4.95 E+05$ & $1.61 \mathrm{E}+07$ & $4.00 \mathrm{E}+01$ & $1.53 \mathrm{E}+09$ & $1.41 \mathrm{E}+09$ & $1.11 \mathrm{E}+05$ & $1.41 \mathrm{E}+09$ & $1.08 \mathrm{E}+00$ & $1.24 \mathrm{E}+04$ & $3.25 \mathrm{E}+01$ \\
\hline Beta & $2.04 \mathrm{E}+07$ & $6.16 \mathrm{E}+08$ & $1.55 \mathrm{E}+03$ & $6.29 \mathrm{E}+10$ & $5.41 \mathrm{E}+10$ & $4.29 \mathrm{E}+06$ & $5.41 \mathrm{E}+10$ & $1.16 \mathrm{E}+00$ & $1.32 \mathrm{E}+04$ & $3.02 \mathrm{E}+01$ \\
\hline $\mathrm{H}-3$ & $6.00 \mathrm{E}+02$ & $6.00 \mathrm{E}+02$ & $6.00 \mathrm{E}+02$ & $1.85 \mathrm{E}+06$ & $5.27 \mathrm{E}+04$ & $1.66 \mathrm{E}+06$ & $1.71 \mathrm{E}+06$ & $1.08 \mathrm{E}+00$ & $1.00 \mathrm{E}+00$ & $1.00 \mathrm{E}+00$ \\
\hline C-14 & N.M. & N.M. & N.M. & - & - & - & - & - & - & - \\
\hline $\mathrm{Al}-26$ & $9.00 \mathrm{E}+00$ & $8.70 \mathrm{E}+03$ & 3.00E-01 & $2.77 \mathrm{E}+04$ & $7.64 \mathrm{E}+05$ & $8.29 \mathrm{E}+02$ & $7.65 E+05$ & 3.63E-02 & $3.00 \mathrm{E}+01$ & $9.67 \mathrm{E}+02$ \\
\hline $\mathrm{Ni}-59$ & $3.65 E+03$ & $1.00 \mathrm{E}+05$ & $6.00 \mathrm{E}+00$ & $1.13 \mathrm{E}+07$ & $8.79 \mathrm{E}+06$ & $1.66 \mathrm{E}+04$ & $8.80 \mathrm{E}+06$ & $1.28 \mathrm{E}+00$ & $6.08 \mathrm{E}+02$ & $2.74 \mathrm{E}+01$ \\
\hline $\mathrm{Ni}-63$ & $4.02 \mathrm{E}+05$ & $1.00 \mathrm{E}+07$ & $6.00 \mathrm{E}+02$ & $1.24 \mathrm{E}+09$ & $8.79 \mathrm{E}+08$ & $1.66 \mathrm{E}+06$ & $8.80 \mathrm{E}+08$ & $1.41 \mathrm{E}+00$ & $6.70 \mathrm{E}+02$ & $2.49 \mathrm{E}+01$ \\
\hline Co-60 & $7.93 \mathrm{E}+03$ & $1.95 \mathrm{E}+05$ & 2.97E-01 & $2.44 \mathrm{E}+07$ & $1.71 \mathrm{E}+07$ & $8.21 \mathrm{E}+02$ & $1.71 \mathrm{E}+07$ & $1.43 \mathrm{E}+00$ & $2.67 \mathrm{E}+04$ & $2.46 \mathrm{E}+01$ \\
\hline
\end{tabular}


WSRC-TR-2005-00309

Revision 0

\begin{tabular}{|c|c|c|c|c|c|c|c|c|c|c|}
\hline Analyte & $\begin{array}{c}\text { Blended } \\
\text { Feed }\end{array}$ & Concentrate & Condensate & $\begin{array}{c}\text { Blended } \\
\text { Feed }^{\mathrm{a}}\end{array}$ & Concentrate $^{b}$ & Condensate $^{c}$ & $\begin{array}{l}\text { Concentrate } \\
\text { +Condensate }\end{array}$ & $\begin{array}{c}\text { Ratio of } \\
\text { In vs. Out }\end{array}$ & $\begin{array}{l}\text { Decontamination } \\
\text { Factor for } \\
\text { Blended Feed and } \\
\text { Condensate }\end{array}$ & $\begin{array}{c}\text { Concentration } \\
\text { Factor for } \\
\text { Blended Feed } \\
\text { and Concentrate }\end{array}$ \\
\hline Units & $(d / \mathbf{m} / \mathbf{m L})$ & $(d / \mathbf{m} / \mathbf{m L})$ & $(d / m / m L)$ & $(d / m)$ & $(d / m)$ & $(d / m)$ & $(d / m)$ & & & \\
\hline Se-79 & $1.80 \mathrm{E}+02$ & $4.90 \mathrm{E}+04$ & 1.10E-02 & $5.55 \mathrm{E}+05$ & $4.30 \mathrm{E}+06$ & $3.04 \mathrm{E}+01$ & $4.30 \mathrm{E}+06$ & $1.29 \mathrm{E}-01$ & $1.64 \mathrm{E}+04$ & $2.72 \mathrm{E}+02$ \\
\hline Sr-90 & $7.96 \mathrm{E}+06$ & $2.22 \mathrm{E}+08$ & $2.00 \mathrm{E}+03$ & $2.45 \mathrm{E}+10$ & $1.95 \mathrm{E}+10$ & $5.53 \mathrm{E}+06$ & $1.95 \mathrm{E}+10$ & $1.26 \mathrm{E}+00$ & $3.98 \mathrm{E}+03$ & $2.79 \mathrm{E}+01$ \\
\hline Nb-94 & $4.00 \mathrm{E}+01$ & $2.90 \mathrm{E}+04$ & $3.00 \mathrm{E}-01$ & $1.23 \mathrm{E}+05$ & $2.55 \mathrm{E}+06$ & $8.29 \mathrm{E}+02$ & $2.55 \mathrm{E}+06$ & 4.84E-02 & $1.33 \mathrm{E}+02$ & $7.25 \mathrm{E}+02$ \\
\hline Tc-99 & $1.57 \mathrm{E}+03$ & $3.87 E+04$ & $7.00 \mathrm{E}+00$ & $4.84 \mathrm{E}+06$ & $3.40 \mathrm{E}+06$ & $1.94 \mathrm{E}+04$ & $3.42 \mathrm{E}+06$ & $1.42 \mathrm{E}+00$ & $2.24 \mathrm{E}+02$ & $2.46 \mathrm{E}+01$ \\
\hline Ru-106 & $3.00 \mathrm{E}+02$ & $3.50 \mathrm{E}+05$ & $2.00 \mathrm{E}+00$ & $9.25 \mathrm{E}+05$ & $3.07 \mathrm{E}+07$ & $5.53 \mathrm{E}+03$ & $3.08 \mathrm{E}+07$ & $3.01 \mathrm{E}-02$ & $1.50 \mathrm{E}+02$ & $1.17 \mathrm{E}+03$ \\
\hline Sb-125 & $5.24 \mathrm{E}+02$ & $1.40 \mathrm{E}+04$ & 3.30E-02 & $1.62 \mathrm{E}+06$ & $1.23 \mathrm{E}+06$ & $9.12 \mathrm{E}+01$ & $1.23 \mathrm{E}+06$ & $1.31 \mathrm{E}+00$ & $1.59 \mathrm{E}+04$ & $2.67 \mathrm{E}+01$ \\
\hline Sn-126 & $4.00 \mathrm{E}+01$ & $3.70 \mathrm{E}+04$ & 8.00E-01 & $1.23 \mathrm{E}+05$ & $3.25 E+06$ & $2.21 \mathrm{E}+03$ & $3.25 E+06$ & 3.79E-02 & $5.00 \mathrm{E}+01$ & $9.25 \mathrm{E}+02$ \\
\hline Sb-126 & $4.00 \mathrm{E}+01$ & $3.70 \mathrm{E}+04$ & $3.00 \mathrm{E}-01$ & $1.23 \mathrm{E}+05$ & $3.25 \mathrm{E}+06$ & $8.29 \mathrm{E}+02$ & $3.25 \mathrm{E}+06$ & 3.79E-02 & $1.33 \mathrm{E}+02$ & $9.25 \mathrm{E}+02$ \\
\hline $\mathrm{I}-129$ & $7.35 \mathrm{E}+00$ & $7.35 \mathrm{E}+00$ & $7.35 \mathrm{E}+00$ & $2.27 \mathrm{E}+04$ & $6.46 \mathrm{E}+02$ & $2.03 \mathrm{E}+04$ & $2.10 \mathrm{E}+04$ & $1.08 \mathrm{E}+00$ & $1.00 \mathrm{E}+00$ & $1.00 \mathrm{E}+00$ \\
\hline Cs-134 & $1.00 \mathrm{E}+02$ & $3.30 \mathrm{E}+04$ & $3.00 \mathrm{E}-01$ & $3.08 \mathrm{E}+05$ & $2.90 \mathrm{E}+06$ & $8.29 \mathrm{E}+02$ & $2.90 \mathrm{E}+06$ & $1.06 \mathrm{E}-01$ & $3.33 \mathrm{E}+02$ & $3.30 \mathrm{E}+02$ \\
\hline Cs-135 & $2.40 \mathrm{E}+00$ & $8.30 \mathrm{E}+01$ & $1.70 \mathrm{E}-04$ & $7.40 \mathrm{E}+03$ & $7.29 \mathrm{E}+03$ & 4.70E-01 & $7.29 \mathrm{E}+03$ & $1.01 \mathrm{E}+00$ & $1.41 \mathrm{E}+04$ & $3.46 \mathrm{E}+01$ \\
\hline Cs-137 & $5.77 \mathrm{E}+05$ & $1.97 \mathrm{E}+07$ & $3.90 \mathrm{E}+01$ & $1.78 \mathrm{E}+09$ & $1.73 E+09$ & $1.08 \mathrm{E}+05$ & $1.73 E+09$ & $1.03 \mathrm{E}+00$ & $1.48 \mathrm{E}+04$ & $3.41 \mathrm{E}+01$ \\
\hline Pm-147 & $3.90 \mathrm{E}+05$ & $1.30 \mathrm{E}+07$ & $4.00 \mathrm{E}+02$ & $1.20 \mathrm{E}+09$ & $1.14 \mathrm{E}+09$ & $1.11 \mathrm{E}+06$ & $1.14 \mathrm{E}+09$ & $1.05 \mathrm{E}+00$ & $9.75 \mathrm{E}+02$ & $3.33 \mathrm{E}+01$ \\
\hline Sm-151 & $2.98 \mathrm{E}+05$ & $1.18 \mathrm{E}+07$ & $3.00 \mathrm{E}+02$ & $9.19 \mathrm{E}+08$ & $1.04 \mathrm{E}+09$ & $8.29 \mathrm{E}+05$ & $1.04 \mathrm{E}+09$ & 8.85E-01 & $9.93 \mathrm{E}+02$ & $3.96 \mathrm{E}+01$ \\
\hline Eu-154 & $1.57 \mathrm{E}+04$ & $5.16 \mathrm{E}+05$ & $6.48 \mathrm{E}-01$ & $4.84 \mathrm{E}+07$ & $4.53 \mathrm{E}+07$ & $1.79 \mathrm{E}+03$ & $4.53 \mathrm{E}+07$ & $1.07 \mathrm{E}+00$ & $2.42 \mathrm{E}+04$ & $3.29 \mathrm{E}+01$ \\
\hline Eu-155 & $7.00 \mathrm{E}+03$ & $1.90 \mathrm{E}+05$ & $1.00 \mathrm{E}+00$ & $2.16 \mathrm{E}+07$ & $1.67 \mathrm{E}+07$ & $2.76 \mathrm{E}+03$ & $1.67 \mathrm{E}+07$ & $1.29 \mathrm{E}+00$ & $7.00 \mathrm{E}+03$ & $2.71 \mathrm{E}+01$ \\
\hline Ra-226 & $1.00 \mathrm{E}+03$ & $1.40 \mathrm{E}+06$ & $6.00 \mathrm{E}+00$ & $3.08 \mathrm{E}+06$ & $1.23 \mathrm{E}+08$ & $1.66 \mathrm{E}+04$ & $1.23 \mathrm{E}+08$ & $2.51 \mathrm{E}-02$ & $1.67 \mathrm{E}+02$ & $1.40 \mathrm{E}+03$ \\
\hline Th-230 & 4.36E-01 & $5.09 \mathrm{E}+00$ & $2.00 \mathrm{E}-01$ & $1.34 \mathrm{E}+03$ & $4.47 \mathrm{E}+02$ & $5.53 \mathrm{E}+02$ & $1.00 \mathrm{E}+03$ & $1.34 \mathrm{E}+00$ & $2.18 \mathrm{E}+00$ & $1.17 \mathrm{E}+01$ \\
\hline Th-232 & 1.39E-01 & $3.50 \mathrm{E}+00$ & 5.00E-06 & $4.29 \mathrm{E}+02$ & $3.07 \mathrm{E}+02$ & 1.38E-02 & $3.07 \mathrm{E}+02$ & $1.39 \mathrm{E}+00$ & $2.78 \mathrm{E}+04$ & $2.52 \mathrm{E}+01$ \\
\hline U-233 & $1.04 \mathrm{E}+01$ & $7.01 \mathrm{E}+00$ & $3.00 \mathrm{E}-01$ & $3.21 \mathrm{E}+04$ & $6.16 \mathrm{E}+02$ & $8.29 \mathrm{E}+02$ & $1.45 \mathrm{E}+03$ & $2.22 \mathrm{E}+01$ & $3.47 \mathrm{E}+01$ & $6.74 \mathrm{E}-01$ \\
\hline U-234 & $2.82 \mathrm{E}+01$ & $1.03 \mathrm{E}+03$ & $1.00 \mathrm{E}-01$ & $8.69 \mathrm{E}+04$ & $9.05 \mathrm{E}+04$ & $2.76 \mathrm{E}+02$ & $9.08 \mathrm{E}+04$ & $9.58 \mathrm{E}-01$ & $2.82 \mathrm{E}+02$ & $3.65 \mathrm{E}+01$ \\
\hline U-235 & 8.40E-01 & $3.22 \mathrm{E}+01$ & 5.00E-05 & $2.59 \mathrm{E}+03$ & $2.83 \mathrm{E}+03$ & $1.38 \mathrm{E}-01$ & $2.83 \mathrm{E}+03$ & 9.15E-01 & $1.68 \mathrm{E}+04$ & $3.83 \mathrm{E}+01$ \\
\hline U-236 & 7.53E-01 & $3.12 \mathrm{E}+01$ & $7.00 \mathrm{E}-04$ & $2.32 \mathrm{E}+03$ & $2.74 \mathrm{E}+03$ & $1.94 \mathrm{E}+00$ & $2.74 \mathrm{E}+03$ & $8.46 \mathrm{E}-01$ & $1.08 \mathrm{E}+03$ & $4.14 \mathrm{E}+01$ \\
\hline U-238 & $2.44 \mathrm{E}+01$ & $8.30 \mathrm{E}+02$ & $1.72 \mathrm{E}-03$ & $7.52 \mathrm{E}+04$ & $7.29 \mathrm{E}+04$ & $4.76 \mathrm{E}+00$ & $7.29 \mathrm{E}+04$ & $1.03 \mathrm{E}+00$ & $1.42 \mathrm{E}+04$ & $3.40 \mathrm{E}+01$ \\
\hline $\mathrm{Np}-237$ & $5.44 \mathrm{E}+01$ & $2.05 \mathrm{E}+03$ & 8.00E-03 & $1.68 \mathrm{E}+05$ & $1.80 \mathrm{E}+05$ & $2.21 \mathrm{E}+01$ & $1.80 \mathrm{E}+05$ & 9.31E-01 & $6.80 \mathrm{E}+03$ & $3.77 \mathrm{E}+01$ \\
\hline $\mathrm{Pu}-238$ & $1.07 \mathrm{E}+05$ & $3.40 \mathrm{E}+06$ & $9.00 \mathrm{E}+00$ & $3.30 \mathrm{E}+08$ & $2.99 \mathrm{E}+08$ & $2.49 \mathrm{E}+04$ & $2.99 \mathrm{E}+08$ & $1.10 \mathrm{E}+00$ & $1.19 \mathrm{E}+04$ & $3.18 \mathrm{E}+01$ \\
\hline Pu-239 & $5.12 \mathrm{E}+04$ & $1.62 \mathrm{E}+06$ & 7.00E-01 & $1.58 \mathrm{E}+08$ & $1.42 \mathrm{E}+08$ & $1.94 \mathrm{E}+03$ & $1.42 \mathrm{E}+08$ & $1.11 \mathrm{E}+00$ & $7.31 E+04$ & $3.16 \mathrm{E}+01$ \\
\hline Pu-240 & $1.75 \mathrm{E}+04$ & $5.49 \mathrm{E}+05$ & $5.00 \mathrm{E}+00$ & $5.39 \mathrm{E}+07$ & $4.82 \mathrm{E}+07$ & $1.38 \mathrm{E}+04$ & $4.82 \mathrm{E}+07$ & $1.12 \mathrm{E}+00$ & $3.50 \mathrm{E}+03$ & $3.14 \mathrm{E}+01$ \\
\hline Pu-241 & $2.29 \mathrm{E}+05$ & $7.20 \mathrm{E}+06$ & $2.00 \mathrm{E}+01$ & $7.06 \mathrm{E}+08$ & $6.33 \mathrm{E}+08$ & $5.53 \mathrm{E}+04$ & $6.33 \mathrm{E}+08$ & $1.12 \mathrm{E}+00$ & $1.15 \mathrm{E}+04$ & $3.14 \mathrm{E}+01$ \\
\hline $\mathrm{Pu}-242$ & $1.30 \mathrm{E}+01$ & $4.04 \mathrm{E}+02$ & $1.00 \mathrm{E}-01$ & $4.01 \mathrm{E}+04$ & $3.55 \mathrm{E}+04$ & $2.76 \mathrm{E}+02$ & $3.58 \mathrm{E}+04$ & $1.12 \mathrm{E}+00$ & $1.30 \mathrm{E}+02$ & $3.11 \mathrm{E}+01$ \\
\hline
\end{tabular}


WSRC-TR-2005-00309

Revision 0

\begin{tabular}{|c|c|c|c|c|c|c|c|c|c|c|}
\hline Analyte & $\begin{array}{c}\text { Blended } \\
\text { Feed } \\
\end{array}$ & Concentrate & Condensate & $\begin{array}{c}\text { Blended } \\
\text { Feed }^{\mathrm{a}}\end{array}$ & Concentrate $^{\mathbf{b}}$ & Condensate $^{c}$ & $\begin{array}{l}\text { Concentrate } \\
\text { +Condensate }\end{array}$ & $\begin{array}{c}\text { Ratio of } \\
\text { In vs. Out }\end{array}$ & $\begin{array}{l}\text { Decontamination } \\
\text { Factor for } \\
\text { Blended Feed and } \\
\text { Condensate }\end{array}$ & $\begin{array}{c}\text { Concentration } \\
\text { Factor for } \\
\text { Blended Feed } \\
\text { and Concentrate }\end{array}$ \\
\hline Units & $(\mathrm{d} / \mathbf{m} / \mathbf{m L})$ & $(d / \mathbf{m} / \mathbf{m L})$ & $(\mathrm{d} / \mathbf{m} / \mathbf{m L})$ & $(d / m)$ & $(d / m)$ & $(d / m)$ & $(d / m)$ & & & \\
\hline Am-241 & $5.04 \mathrm{E}+04$ & $1.46 \mathrm{E}+06$ & $2.00 \mathrm{E}+00$ & $1.55 \mathrm{E}+08$ & $1.28 \mathrm{E}+08$ & $5.53 \mathrm{E}+03$ & $1.28 \mathrm{E}+08$ & $1.21 \mathrm{E}+00$ & $2.52 \mathrm{E}+04$ & $2.90 \mathrm{E}+01$ \\
\hline Am-243 & $3.61 \mathrm{E}+03$ & $1.17 \mathrm{E}+05$ & $4.00 \mathrm{E}+00$ & $1.11 \mathrm{E}+07$ & $1.03 \mathrm{E}+07$ & $1.11 \mathrm{E}+04$ & $1.03 \mathrm{E}+07$ & $1.08 \mathrm{E}+00$ & $9.03 \mathrm{E}+02$ & $3.24 \mathrm{E}+01$ \\
\hline $\mathrm{Cm}-244$ & $2.29 \mathrm{E}+05$ & $9.47 \mathrm{E}+06$ & $9.00 \mathrm{E}+02$ & $\begin{array}{c}70595441 \\
1.9\end{array}$ & $8.32 E+08$ & $2.49 \mathrm{E}+06$ & $8.34 \mathrm{E}+08$ & $8.46 \mathrm{E}-01$ & $2.54 \mathrm{E}+02$ & $4.14 \mathrm{E}+01$ \\
\hline $\begin{array}{c}\text { Radiation } \\
\text { Control } \\
\text { Guide } \\
\text { (RCG) }\end{array}$ & $1.51 \mathrm{E}+01$ & $5.13 \mathrm{E}+02$ & $1.06 \mathrm{E}-03$ & $4.66 \mathrm{E}+01$ & $4.51 \mathrm{E}+01$ & 2.93E-03 & $4.51 \mathrm{E}+01$ & $1.03 \mathrm{E}+00$ & $1.43 \mathrm{E}+04$ & $3.39 E+01$ \\
\hline
\end{tabular}

${ }^{\mathrm{a}}$ Multiplied Column 2 by $2.968 \mathrm{~L}$ to obtain mass or by $2968 \mathrm{~mL}$ to obtain disintegrations/minute

${ }^{\mathrm{b}}$ Multiplied Column 3 by $0.0879 \mathrm{~L}$ to obtain mass or by $87.9 \mathrm{~mL}$ to obtain disintegrations/minute

${ }^{\mathrm{c}}$ Multiplied Column 4 by $0.2765 \mathrm{~L}$ to obtain mass or by $2765 \mathrm{~mL}$ to obtain disintegrations/minute 
Distribution:

E. W. Holtzscheiter, SRNL

J. C. Griffin, SRNL

D. A. Crowley, 999-W

S. L. Marra, 999-W

T. B. Calloway, 999-W

N. E. Bibler, SRNL

C.M. Jantzen, SRNL

J. R. Harbour, 773-42A

G. G. Wicks, SRNL

W. E. Daniel, 999-W

T. L. Fellinger, SRNL

C.C. Herman, 773-42A

D. T. Herman, 735-11A

D. K. Peeler, 999-W

M. E. Stone, 999-W

M. E. Smith, 773-42A

D. C. Koopman, 773-42A

T. B. Edwards, 773-42A

S. D. Fink, SRNL

M. S. Miller, 704-S

J. E. Occhipinti, 704-S

R. M. Hoeppel, 704-27S

H. H. Elder, 703-H

M. A. Rios Armstrong, 766-H

J. F. Iaukea, 704-30S

J. W. Ray, 704-S

F. A. Washburn, 704-27S

W. B. Van-Pelt, 704-S

S. G. Phillips, 704-27S

A. V. Staub, 704-27S 